\title{
SUMMARY OF RESEARCH RESULTS ON BACTERIAL DEGRADATION OF TRIFLUOROACETATE (TFA), OCTOBER, 1993 - OCTOBER, 1995
}

by Leah J. Matheson, Janet R. Guidetti, Pieter T. Visscher , Jeffra K. Schaefer, and Ronald S. Oremland

\section{U.S. GEOLOGICAL SURVEY}

Open File Report 96-219

Prepared in Cooperation with the ALTERNATIVE FLUOROCARBONS ENVIRONMENTAL ASSESSMENT STUDY (AFEAS)

Menlo Park, California 1996

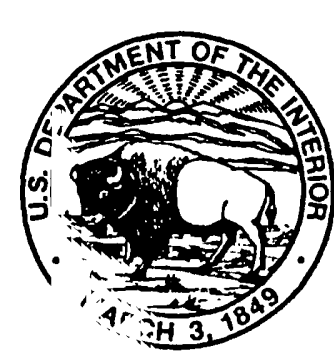




\title{
U.S. DEPARTMENT OF THE INTERIOR \\ BRUCE BABBITT, Secretary
}

\author{
U.S. GEOLOGICAL SURVEY
}

Gordon P. Eaton, Director

The use of firm, trade, and brand names in this report is for identification purposes only and does not constitute endorsement by the U.S. Geological Survey

For addtional information write to:

U.S. Geological Survey

345 Middlefield Road

Menio Park, California 94025
Copies of this report can be purchased from:

U.S. Geological Survey Information Services Box 25286, Mail Stop 417

Denver Federal Center Denver, CO 80225-0046 


\section{CONTENTS}

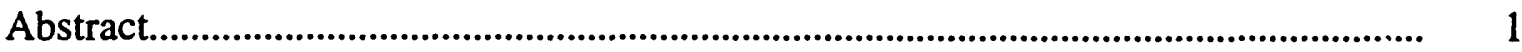

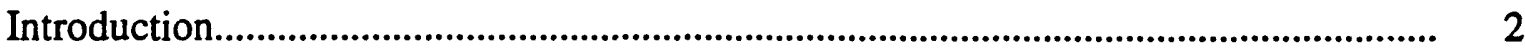

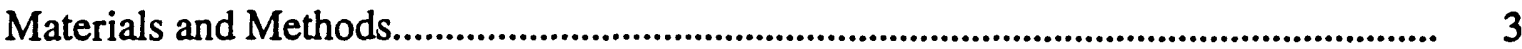

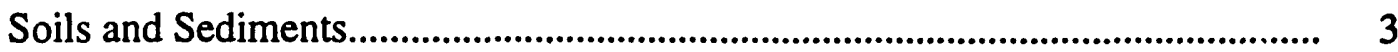

Pre-incubation of Sediments with Fluorinated Acetates........................................... 4

Inhibitory Effect of Fluorinated Acetates on Methanogenesis in Sediment

Slurries.............................................................................................. 4

Analyses of Gaseous and Liquid-Phase Products.................................................... 4

Experiments with Bacterial Cultures................................................................ 5

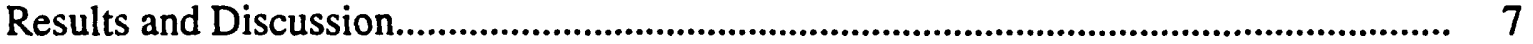

Experiments with Estuarine Sediments............................................................ 7

Inhibition by Fluorinated Acetates............................................................ 7

Degradation of TFA under methanogenic and sulfate-reducing conditions.. 7

Inhibition of TFA degradation under nitrate-reducing conditions................. 7

Degradation of TFA in sediments amended with other electron

acceptors................................................................................................. 8

Degradation of $2-14$ C-TFA vs. $1-14$ C-TFA............................................ 8

Degradation of TFA in anaerobic sediments plus hydrogen.......................... 8

Degradation of TFA using various TFA concentrations................................. 8

Degradation of TFA in sediments amended with various electron

acceptors................................................................................................ 8

Degradation of TFA in nitrogen-amended sediments.................................. $\quad 8$

Degradation of TFA in sediments pre-incubated with fluorinated acetates...................................................................................... 9

Degradation of TFA in sediments collected from Bolinas Bay, Calif.......... 9

Experiments with Freshwater Sediments................................................................ 9

Experiments with Sacramento Delta Peat Soil....................................................... 9

Experiments with Forest Soil........................................................................... 10

Experiments with Small Cores from Estuarine Sediments...................................... 11

Experiments with Bacterial Cultures................................................................. 11

Conclusions...............................................................................................................

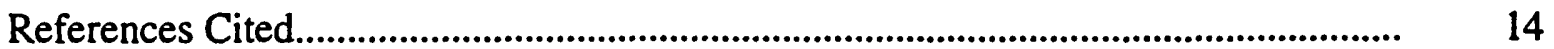




\section{FIGURES}

1. Methanogenesis in anaerobic South San Francisco Bay saltmarsh slurries. from January through March 1994, with varying TFA, DFA, and MFA additions

2. Methanogenesis and $\mathrm{CO}_{2}$ production in anaerobic South San Francisco P ay saltmarsh slurries from 4/12/94, amended with $20 \mathrm{mM}$ sulfate and 2-14C-TFA................. 18 3. Degradation of 2-14C-TFA in anaerobic South San Francisco Bay saltmarsh slurries from 5/11/94 amended with $20 \mathrm{mM}$ sulfate.

4. Degradation of TFA in anaerobic South San Francisco Bay saltmarsh slurries from $6 / 7 / 94$, amended with varying concentrations of 2-14C-TFA and $20 \mathrm{mM}$ nitrate.

5. Degradation of 2-14C-TFA in anaerobic South San Francisco Bay saltma-sh sediments amended with sulfate, $\mathrm{MnO}_{2}, \mathrm{Fe}$ (III)NTA, or TMA. 21 6. Degradation of 14C-TFA in South San Francisco Bay saltmarsh sediment collected and slurried anaerobically on $5 / 17 / 95$. 22 7. Degradation of 14 C-TFA in South San Francisco Bay saltmarsh sediment collected and slurried anaerobically on $7 / 13 / 95$. 23

8. Degradation of 14 C-TFA in South San Francisco Bay saltmarsh sediments collected on $5 / 3 / 95$ at various depths, slurried anaerobically with and without $20 \mathrm{mM}$ sulfate. 24 9. Degradation of $14 \mathrm{C}$-TFA in South San Francisco Bay saltmarsh sediment collected and slurried anaerobically on 8/3/95. All received $0.91 \mu \mathrm{Ci}(0.84 \mu \mathrm{M}) 2$-14C-TFA. 25 10. Degradation of 14C-TFA in South San Francisco Bay saltmarsh sediment collected and slurried anaerobically on $8 / 28 / 95$ with $20 \mathrm{mM}$ sulfate. 26 11. Degradation of 14C-TFA in South San Francisco Bay saltmarsh sediment collected and slurried anaerobically on 10/3/95 with $20 \mathrm{mM}$ sulfate. 27 12. Degradation of $14 \mathrm{C}$-TFA in South San Francisco Bay saltmarsh sediments collected and slurried anaerobically on 12/9/94, with and without sulfate. 28 13. Degradation of $14 \mathrm{C}$-TFA in South San Francisco Bay saltmarsh sediments collected and slurried anaerobically on $12 / 28 / 94$, with and without sulfate. 29 14. Degradation of $14 \mathrm{C}-\mathrm{TFA}$ in South San Francisco Bay saltmarsh sediments collected and slurried anaerobically on 1/24/95, with and without sulfate. 30 15. Degradation of 14C-TFA in South San Francisco Bay saltmarsh sediment collected and slurried anaerobically on $6 / 22 / 95$, with varying 2-14C-TFA concentrations. 31 16. Degradation of $14 \mathrm{C}$-TFA in South San Francisco Bay saltmarsh sediment collected on $8 / 28 / 95$ and slurried anaerobically with various electron donors on $8 / 29 / 95$. 32 17. Degradation of $14 \mathrm{C}$-TFA in South San Francisco Bay saltmarsh sediment collected $6 / 93$ and slurried anaerobically, with or without on 5/23/95.

33 18. Degradation of $14 \mathrm{C}-\mathrm{TFA}$ in South San Francisco Bay saltmarsh sediment collected from various depths and slurried anaerobically, with sulfate or TMA, on 6/5/95. 34 19. Degradation of 14C-TFA in South San Francisco Bay saltmarsh sediment collected and slurried anaerobically on $8 / 9 / 95$ with $\mathrm{NH}_{4} \mathrm{Cl}$ and acetate.

20. Degradation of 14C-TFA in South San Francisco Bay saltmarsh sediment slurries preincubated with TFA, DFA, MFA, acetate, or no addition. 21. Degradation of $14 \mathrm{C}$-TFA in Bolinas Bay saltmarsh sediment from the south sampling location. Collected on 5/3/95 and slurried anaerobically on 5/26/95. 
22. Degradation of $14 \mathrm{C}-\mathrm{TFA}$ in Bolinas Bay saltmarsh sediment from the north sampling location. Collected on 5/3/95 and slurried anaerobically on 5/26/95.

23. Degradation of $14 \mathrm{C}-\mathrm{TFA}$ in Searsville lake freshwater sediment collected and slurried anaerobically on $10 / 6 / 93$.

24. Degradation of 14 C-TFA in Searsville Lake freshwater sediments collerted and slurried anaerobically on $1 / 18 / 95$ and amended with varying concentrations of $1-14 \mathrm{C}$ TFA and 2-14C-TFA

25. Degradation of 14 C-TFA in Searsville Lake sediment collected on 10/93 and slurried anaerobically on $5 / 23 / 95$.

26. Degradation of 14 C-TFA in Searsville Lake sediment collected and slurried anaerobically and aerobically on $8 / 8 / 95$.

27. Degradation of 14C-TFA in Sacramento Delta peat soil collected on 10/7/91 and slurried anaerobically on $4 / 1 / 94$ with nitrate.

28. Degradation of 14C-TFA in Sacramento Delta peat soil collected 8/9/95 and slurried aerobically on 8/24/95 with $\mathrm{CH}_{4}$ and $\mathrm{O}_{2}$ 44 29. Degradation of 14 C-TFA in forest soil collected 6/14/95 and slurried anaerobically or aerobically on $6 / 16 / 95$.

30. Degradation of 14 C-TFA in forest soil collected 6/14/95 and slurried ae-obically on $6 / 26 / 95$. 46

31. Degradation of $14 \mathrm{C}$-TFA in forest soil from site 1 , collected $7 / 7 / 95$. Slurried aerobically and anaerobically on $7 / 11 / 95$.

32. Degradation of $14 \mathrm{C}$-TFA in forest soil from site 2 , collected $7 \pi / 95$. Slurried aerobically and anaerobically on $7 / 11 / 95$ 33. Degradation of $14 \mathrm{C}$-TFA in forest soil collected $6 / 14 / 95$ and slurried ae-obically on $6 / 30 / 95$ with $\mathrm{CH}_{4}$ and $\mathrm{O}_{2}$

34. Degradation of $14 \mathrm{C}$-TFA in forest soil collected $6 / 14 / 95$ and slurried anaerobically on $6 / 30 / 95$ with sulfate.

35. Degradation of $14 \mathrm{C}$-TFA in Forest soil collected $7 / 7 / 95$ and slurried ancerobically on $8 / 25 / 95$ with $5 \mathrm{mM}$ sulfate in phosphate buffered medium, $\mathrm{pH} 6.8$.

36. Degradation of 14C-TFA in South San Francisco Bay saltmarsh small cre experiment.

37. Degradation of 14C-TFA in South San Francisco Bay saltmarsh small c vre experiment.

38. Degradation of $14 \mathrm{C}$-TFA in South San Francisco Bay saltmarsh small cre experiment.

39. Degradation of $14 \mathrm{C}$-TFA in San Francisco Marina small core experiment.

40. Degradation of 14 C-TFA in Bolinas Bay small core experiment

41. Effects of varying TFA concentrations on growth of Methanosarcina mazei S-6 and

Desulfobacter curvatus growing on acetate.

42. Methanosarcina mazei S-6 growing acetate in the presence of 2-14C-TFA. 


\title{
SUMMARY OF RESEARCH RESULTS ON \\ BACTERIAL DEGRADATION OF \\ TRIFLUOROACETATE (TFA), OCTOBER, 1993 - \\ OCTOBER, 1995
}

By Leah J. Matheson, Janet R. Guidetti, Pieter T. Visscher, Jeffra K. Schaefer, and Ronald S. Oremland

\begin{abstract}
Addition of $2-{ }^{14} \mathrm{C}$-trifluoroacetate (TFA) to methanogenic freshwater sediments resulted in its sequential defluorination to $2-{ }^{14} \mathrm{C}$-acetate, followed by the formation of ${ }^{14} \mathrm{CH}_{4}$. Sulfate-reducing freshwater and saltmarsh sediments also defluorinated $2-14 \mathrm{C}$ TFA to $2-{ }^{14} \mathrm{C}$-acetate, which was subsequently oxidized to ${ }^{14} \mathrm{CO}_{2}$. Degradation of $14 \mathrm{C}$ TFA was observed in these sediments in experiments conducted from September 1993 to June 1994. However, subsequent experiments with these materials have not shown ${ }^{14} \mathrm{C}$ TFA degradation. It is not known why the sediments lost the ability to degrade ${ }^{14} \mathrm{C}$-TFA and several experiments were undertaken to reestablish their ability to biodegrade ${ }^{14} \mathrm{C}$ TFA. These experiments included addition of various electron donors and acceptors, as well as pre-incubation of sediments with unlabeled, fluorinated acetates. In addition, several other soils and sediments were screened for their ability to degrade ${ }^{14} \mathrm{C}$-TFA, including aerobically and anaerobically incubated soils from a northeastern hardwc ?d forest which had received prior exposure to TFA. We did not detect significant ${ }^{14}{ }_{C}$-TFA biodegradation in any of the sediment systems studied, regardless of whether or not they were manipulated with amendments of electron donors, acceptors, or pre-incubated with fluorinated acetates. Methane-oxidizing soils were also unable to degrade ${ }^{14} \mathrm{C}$-TFA. Additionally, bacterial isolates which utilize acetate, as well as known dehalogenat' $\mathrm{ng}$ bacteria, were assayed for the ability to degrade ${ }^{14} \mathrm{C}$-TFA. None of the pure cultures of methanogens, sulfate-reducing bacteria, or selected dehalogenating bacteria were able to degrade 14 C-TFA. The presence of labeled or unlabeled TFA did not appear to inhibit the growth of any of these bacteria. We conclude that TFA is a molecule which is generally refractory to microbial degradation.
\end{abstract}




\section{INTRODUCTION}

Recently, much concern about trifluoroacetate (TFA) has arisen because of findings that this compound may accumulate in the biosphere (Tromp and others, 1995). TFA is a predicted product of the tropospheric photolysis and hydrolysis of certain hydrochlorofluorocarbons (HCFCs) and hydrofluorocarbons (HFCs) (Franklin, 1953; Wallington and others, 1994). For example, $\mathrm{HFC}-134 \mathrm{a}\left(\mathrm{CF}_{3} \mathrm{CFH}_{2}\right)$ undergoes a reaction sequence which forms a trifluoroacetyl compound, which is then hydrolyzed in clo'ids to form TFA (Franklin, 1993). The TFA produced from these reactions is predicted tc be deposited on the Earth's surface through wet or dry deposition. TFA has not been shown to be acutely toxic to humans (Rusch, 1994), although it may be phytotoxic (Thomoson, 1994). However, monofluoroacetate (MFA) is a tricarboxylic acid cycle inhibitor and is known to be acutely toxic to humans, as well as most life forms (Calver and King, 1986).

TFA is thought to be highly resistant to degradation in the biosphere, leading to concern that TFA could accumulate in ground waters and the oceans (Chumley, 19?2; Franklin, 1993; Tromp and others, 1995). Tromp and others (1995), in a modeling study, have indicated that TFA could accumulate to $>0.62 \mu \mathrm{M}$ in evapotranspirative environments. Although this conclusion may represent extreme conditions, it does seem possible in light of earlier work that suggests this compound is not readily biodegra dable. For example, Hirsch and Alexander (1960) observed that isolates of Nocardia and Pseudomonas sp. were not able to degrade TFA or monofluoroacetate (MFA). Hov'ever, recent work by Visscher and others (1994) has shown that TFA can be biodegraded in both anoxic and oxic sediments. These workers observed that TFA was metabolize t by bacteria in both freshwater and marine sediments (Visscher and others, 1994). Sediments were assayed for TFA-degrading activity under methanogenic, sulfate-reducing, nitratereducing and aerobic conditions. Methanogenic, sulfate-reducing and aerobic slurries of both freshwater and marine sediments were able to degrade TFA. Under anaerobic conditions TFA was reductively defluorinated to acetate, which was then cleaved to $\mathrm{CH}_{4}$ and $\mathrm{CO}_{2}$ under methanogenic conditions, or oxidized to $\mathrm{CO}_{2}$ under sulfate-reducir 9 conditions. When oxygen served as the electron acceptor, TFA was decarboxylated to form fluoroform $\left(\mathrm{CHF}_{3}\right)$ and $\mathrm{CO}_{2}$. The absolute concentration of TFA employed appeared to be a critical factor controlling biodegradation, with little or no activity observed at concentrations $>1.9 \mu \mathrm{M}$, and high activity and degradation efficiencies occurring at sub-micromolar levels (Visscher and others, 1994). These results sugg st that TFA may be consumed in a wide variety of ecosystems and hence may not accumulate in the biosphere.

In light of the attempts to predict the fate of TFA in the environment, the otjective of the studies reported here was to determine if TFA biodegradation was common in a variety of soils and sediments, and to delineate the mechanisms of TFA degradation in nature. We have found that, in contrast of our earlier results, TFA appears widely recalcitrant to biodegradation. 
This research was funded, in part, by the Alternative Fluorocarbons Environmental Assessment Study (AFEAS) under contract number CTR SP9118.17/BP94-23. 


\section{MATERIALS AND METHODS}

\section{Soil And Sediment Experiments}

Sediments (upper $10 \mathrm{~cm}$ ) were collected from four locations: an estuarine saltmarsh in South San Francisco Bay (Oremland and others, 1982); the freshwater Searsville Lake (Smith and Oremland, 1983); a heavily-used yacht harbor in the San Francisco Marina, and an estuarine saltmarsh in Bolinas Bay, Calif. Sediments were. stored in completely filled mason jars at $4{ }^{\circ} \mathrm{C}$ and, unless indicated otherwise, were used within $2 \mathrm{~h}$ of collection. Soil samples from a sub-surface zone of bacterial methane oxidation ( $80 \mathrm{~cm}$ deep) of a peatland soil in the Sacramento Delta were collected by augering (Oremland and Culbertson, 1992), placed in sealed mason jars, and stored at $4^{\circ}$ C. Soil and water were also taken from areas within two ground-water seeps in a northeastern hardwood forest (Hubbard Brook Experimental Forest). One seep had received prior exposure to TFA for approximately one year (Yavitt and Fahey, 199:; S. Tartowski, oral comm.) the other was located hydrologically upgradient and had not been exposed to TFA. These samples were collected in sealed mason jars, shipped at aml ient temperatures and stored at $4{ }^{\circ} \mathrm{C}$ upon receipt in the laboratory.

Soils and sediments from the estuarine sites, hardwood forest, and Searsville. Lake were homogenized in a Waring blender (under $\mathrm{N}_{2}$ for anaerobic incubations) with an equal volume of artificial bay water (ABW) (Oremland and Polcin, 1982) for estuarine slurries or with lakewater for freshwater lake slurries. Forest soils were homogenized with and equal volume of water collected from the site, $1.15 \mathrm{M}$ phosphate buffer or mineral salts medium (Egli and others, 1988) as indicated. Sacramento Delta soils v'ere either weighed in $10 \mathrm{~g}$ portions and used without liquid addition, or slurried with tapwater. Portions of the homogenate $(20 \mathrm{~mL})$ were dispensed into $60-\mathrm{mL}$ serum bottles and crimp-sealed (black butyl rubber stoppers) under air, $\mathrm{N}_{2}, \mathrm{O}_{2}$ plus $\mathrm{CH}_{4}$, or $\mathrm{H}_{2}$ aindicated in the text. Additional oxygen was injected (1-5 mL) into aerobic bottles to insure aerobic conditions during incubation. Similarly, methane was injected (1-5 mL) in the case of methanotrophic incubations. Inhibitors or substrates were added either prior to sealing, or through the stoppers before addition of ${ }^{14} \mathrm{C}$-TFA. Various electron dono-s were added (final concentration in parentheses) to determine whether each might elicit TFA degradation: sodium acetate $(10 \mathrm{mM})$, trimethylamine hydrochloride (TMA; 10 $\mathrm{mM})$, anhydrous D-glucose (5 mM), sodium pyruvate (5 mM), propionic acid (5 ml 1 ), disodium oxalate $(5 \mathrm{mM})$, sodium lactate $(5 \mathrm{mM})$, and sodium benzoate $(5 \mathrm{mM})$. In some cases, ammonium chloride $(0.185 \mathrm{mM})$ was added to $20 \mathrm{~mL}$ sediment slurries to determine if the addition of this nitrogen source elicited TFA degradation. Also, various electron acceptors were added to selected sediment slurries to study their effect on TFA degradation. These included (final concentration): sodium sulfate $(20 \mathrm{mM}$ in saltma-sh sediments; $5 \mathrm{mM}$ in freshwater slurries), sodium nitrate $(20 \mathrm{mM}), \mathrm{Fe}(\mathrm{III})$-nitrilotriaretic acid (NTA; $10 \mathrm{mM}$ ), $\mathrm{FeOOH}$ (amorphous; ca. $0.1 \mathrm{mmole} / \mathrm{L}$ ) and $\mathrm{MnO}_{2}(20 \mathrm{mmol} / \mathrm{L}$ ). Inhibitors were added to some slurries to block the activity of selected populations $c^{f}$ bacteria. 2-Bromoethanesulfonate (BES; $5 \mathrm{mM}$ ) was used to inhibit methanogens, and 
sodium molybdate $(2.5 \mathrm{mM})$ to inhibit sulfate-reducing bacteria (Oremland and Capone, 1988). Heat-killed controls were autoclaved $\left(250 \mathrm{kPa}\right.$ and $121^{\circ} \mathrm{C}$ for $\left.1 \mathrm{~h}\right)$ and then cooled and sealed under the appropriate atmosphere. An aqueous solution of 2-14C-TFA $(0.2$ to $1 \mu \mathrm{Ci} / 0.1 \mathrm{~mL}, 3.7$ to $18.5 \mathrm{nmole} / 0.1 \mathrm{~mL}$, as indicated in text; Amersham Inc., Arlington Heights, Illinois; specific activity $=54 \mathrm{mCi} / \mathrm{mmol}$; purity 99.6 percent) was injected through the stopper and the slurries were incubated in the dark at $21-28^{\circ} \mathrm{C}$, either statically or with shaking ( $200 \mathrm{rpm}$ on a rotary platform shaker). Unless stated otherwise, all experiments were performed in triplicate. In selected experiments, $1-14 \mathrm{C}$-TFA $(0.5$ to $1 \mu \mathrm{Ci} / 0.1 \mathrm{~mL}, 9.4$ to $18.9 \mathrm{nmole} / 0.1 \mathrm{~mL}$, as indicated in text; Amersham Inc., Arlington Heights, Illinois; specific activity $=53 \mathrm{mCi} / \mathrm{mmol}$; purity 98.9 percent) was added to follow the fate of the carboxylic acid group of TFA. All sediment slurries were moritored at periodic intervals for the production of $\mathrm{CH}_{4}, \mathrm{CO}_{2}, \mathrm{~N}_{2} \mathrm{O},{ }^{14} \mathrm{CH}_{4},{ }^{14} \mathrm{CO}_{2}$ and liquidphase products as described below.

\section{Pre-Incubation Of Sediments With Fluorinated Acetates}

To determine whether TFA-degradation could be induced, $250 \mathrm{~mL}$ of San Francisco saltmarsh sediment slurries were pre-incubated with $1 \mu \mathrm{M}$ TFA, difluoroacetate (DFA) or MFA in $500 \mathrm{~mL}$ Erlenmeyer flasks. The flasks were sealed under $\mathrm{N}_{2}$ with recessed butyl rubber stoppers and incubated on a platform shaker at $28^{\circ} \mathrm{C}$ for approximately one month. The flasks were then subsampled by removing $10 \mathrm{~mL}$. of the slurry through the stopper with a syringe fitted with an 18 gauge needle. The subsample was placed in a $\mathrm{N}_{2}$-sparged 20 -mL serum bottle, crimp-sealed with butyl rubber stoppers, and injected with $0.5 \mu \mathrm{Ci}(0.46 \mu \mathrm{M}) 2$ - $14 \mathrm{C}$-TFA. The bottles were incubated statically at ca. $20^{\circ} \mathrm{C}$ and the headspace was periodically sampled for analysis of the production of $\mathrm{CH}_{4}, \mathrm{CO}_{2},{ }^{14} \mathrm{CH}_{4},{ }^{14} \mathrm{CO}_{2}$ as described below.

\section{Inhibitory Effect Of Fluorinated Acetates On Methanogenesis In Sediment Slurries}

The inhibition of methanogenesis in San Francisco saltmarsh sediment slurries by TFA, DFA and MFA was studied in sealed $60-\mathrm{mL}$ serum bottles containing $20 \mathrm{~mL}$ slurry and varying concentrations $(0-1 \mathrm{mM})$ of the fluorinated compound. The slurries were incubated at $28{ }^{\circ} \mathrm{C}$ on a platform shaker. Methane production was measured in headspace samples taken at periodic intervals and analyzed as described below. Inhibition was measured as a decrease in the rate of methane production, relative to uninhibited controls, in samples containing fluorinated acetates.

\section{Analyses Of Gaseous And Liquid-Phase Products}

Gaseous-phase products were monitored in each bottle during the incubatior by removing $0.25 \mathrm{~mL}$ sample from the bottle headspaces and analyzing for $\mathrm{CH}_{4}, \mathrm{CO}_{2}, \mathrm{~N}_{2} \mathrm{O}$, 
${ }^{14} \mathrm{CH}_{4},{ }^{14} \mathrm{CO}_{2}$ and ${ }^{14} \mathrm{CHF}_{3}$. Methane was measured by gas chromatography with flame ionization detection (Oremland and Polcin, 1982), and $\mathrm{CO}_{2}$ by thermal conductivit." detector/gas chromatography (GC301 gas chromatograph, HNU Systems Inc., Newton $\mathrm{MA}$; oven temperature $=70^{\circ} \mathrm{C} ; 12 \mathrm{~m}$ Poropak column; He carrier flow $=20 \mathrm{~mL} / \mathrm{m} n$ ). Radioactive gases were determined by gas chromatography with gas-proportional counting (Culbertson and others, 1981). In some of the samples, $\Sigma{ }^{14} \mathrm{CO}_{2}$ (liquid phase plus gas phase) was determined at the end of the incubation by injection of $1.0 \mathrm{~mL}$ of $6 \mathrm{~N}$ $\mathrm{HCl}$ followed by shaking, prior to analysis of the headspace. Positive pressures genorated by the evolution of $\mathrm{CO}_{2}$ in the acidified samples were measured by deflection of a wetted, ground-glass syringe, and used to calculate the internal pressures for final computation of quantity of gas produced. Liquid-phase products, such as acetate, ${ }^{14} \mathrm{C}$ DFA, ${ }^{14} \mathrm{C}$-MFA, and ${ }^{14} \mathrm{C}$-acetate were determined by withdrawing ca. $1 \mathrm{~mL}$ of liquid then removing the sediment by micro-centrifugation $(6,000 \times \mathrm{g}$ for $5 \mathrm{~min})$ followed by sterile filtration $(0.2 \mu \mathrm{m})$. The supernatant was assayed by high-performance liquid chromatography (Culbertson and others, 1988) and emerging fractions were collected in 30 sec intervals

$(\sim 0.3 \mathrm{~mL})$ for determination of radioactivity by liquid scintillation counting (Ecolume scintillation cocktail, ICN, Costa Mesa, CA; Beckmann Model LS 6000SC scintillation counter).

\section{Experiments With Bacterial Cultures}

Several bacterial cultures were assayed for their ability to degrade TFA during growth phase. The isolates were chosen either by their ability to use acetate, hence possible substrate interchangeability with TFA, or because they have known dehalogenating ability. The cultures were grown in Balch tubes $(10 \mathrm{~mL}$ liquid volume in $20 \mathrm{~mL}$ tubes) or serum bottles ( $20 \mathrm{~mL}$ liquid volume in $60 \mathrm{~mL}$ bottles) and amended with 0.5 to $1 \mu \mathrm{Ci}(0.46$ to $0.93 \mu \mathrm{M}){ }^{2-14} \mathrm{C}$-TFA. An aceticlastic methanogen, Methanosarcina mazei strain S-6, was grown at $28^{\circ} \mathrm{C}$ in MS medium (Boone and others, 1989) with acetate, TMA, methanol or $\mathrm{H}_{2}$ plus $\mathrm{CO}_{2}$ as substrates. The cultures were incubated statically at $37^{\circ} \mathrm{C}$. Methane was measured as an indicator of growth. Geobacter metallireducens, a strict anaerobe which couples metal reduction to the oxidation of organic compounds (Lovley and others, 1993), was grown on acetate in a defined medium (Lovley and Phillips, 1988) and incubated statically at ca. $20^{\circ} \mathrm{C}$. The growth of this organism was qualitatively ascertained by the disappearance of an orange-colored ferric iron precipitate, indicating reduction of $\mathrm{Fe}$ (III) to $\mathrm{Fe}$ (II), which forms blue-green or black oxides. Desulfobacter curvatus (Widdel, 1987) was grown statically at $28^{\circ} \mathrm{C}$ on acetate in media described in Widdel and Pfennig (1984) and monitored for growth by mearuring acetate utilization. The anaerobic, sulfur-reducing, acetate oxidizing Desulfuromonas acetoxidans was grown on acetate at ca. $20^{\circ} \mathrm{C}$ statically in basal salts medium (Pfernig and Biebl, 1976). Acetate-utilization was followed as an indicator of growth. Desulfomonile tiedjei, a sulfate-reducing bacterium capable of chlorophenol dehalogenation, was grown statically at $28^{\circ} \mathrm{C}$ on pyruvate in basal media (DeWeerd and 
others, 1990) and growth was measured by absorbance at $680 \mathrm{~nm}$. All cultures were. monitored for purity by light microscopy.

Each bacterial culture was grown in the presence of 0 to $1 \mathrm{mM}$ unlabeled TTA to determine the minimum inhibitory concentration of TFA. Balch tubes containing media, substrate, and TFA were inoculated with the organism and observed for growth.

Subsequently, the culture that had not been exposed to TFA was transferred to triplicate tubes of media and substrate. These cultures then received $0.4 \mu \mathrm{Ci}(0.75)$ of 2-14C-TFA and sampled for gaseous and liquid phase products as described above. Each cultur? was maintained in the presence of $0.1 \mathrm{mM}$ TFA for 1 to 2 months, and subsequently ass'yed for its ability to degrade $2-14$ C-TFA. 


\section{RESULTS AND DISCUSSION}

\section{Experiments With Estuarine Sediments}

Inhibition by fluorinated acetates. Anoxic, estuarine sediment slurries from the San Francisco saltmarsh were amended with varying amounts $(0$ to $100 \mu \mathrm{M})$ of unlabeled TFA, DFA, and MFA to determine if these compounds inhibited methanogenesis. Fig. 1 shows that methane production was not significantly different from the unamendec control over the range of concentrations studied for all compounds.

\section{Degradation of TFA under methanogenic and sulfate-reducing conditions. Anoxic} estuarine sediments collected in April, 1994 from the San Francisco saltmarsh wers not able to defluorinate $0.2 \mu \mathrm{Ci} 2-{ }^{14} \mathrm{C}$-TFA (fig. 2). However, saltmarsh sediments collected one month later, and slurried under sulfate-reducing conditions, were able to oxidize $2 \mu$ Ci $2:{ }^{14} \mathrm{C}$-TFA to ${ }^{14} \mathrm{CO}_{2}$ (fig. 3a). Liquid samples from these slurries showed that TFA was reductively defluorinated to ${ }^{14} \mathrm{C}$-acetate (fig. $3 \mathrm{~b}$ ) which was metabolized to ${ }^{14} \mathrm{CO}_{2}$. The percent recovery of ${ }^{14} \mathrm{CO}_{2}$ from degradation of $2-14 \mathrm{C}$-TFA was 36 percent. Sediment slurries collected prior to December 1994 and amended with sulfate were able to degrade ${ }^{14}$ C-TFA (see fig. 3 and 4; and Visscher and others, 1994). However, sediments collected after December 1994 were not able to degrade ${ }^{14} \mathrm{C}$-TFA under methanogenic or sulfate-reducing conditions (fig. 5-20).

Inhibition of TFA degradation under nitrate-reducing conditions. Earlier work in our laboratory (Visscher and others, 1994) did not detect ${ }^{14}$ C-TFA degradation in slunies containing nitrate. These experiments were repeated with sediments containing with 10 $\mathrm{mM}$ nitrate and varying amounts of $2-{ }^{14} \mathrm{C}$-TFA (fig. 4 ). ${ }^{14} \mathrm{CH}_{4}$ was produced in slurries with $1 \mu \mathrm{Ci}$ and $1.6 \mu \mathrm{Ci} 2-1{ }^{14} \mathrm{C}$-TFA (Fig. $4 \mathrm{c}$ ) and ${ }^{14} \mathrm{CO}_{2}$ was produced in all slurries, except the slurry with the lowest amount of TFA $(0.16 \mu \mathrm{Ci})$. Slurries amended witl $1 \mu \mathrm{Ci}$ had the highest percent recovery of $2-{ }^{14} \mathrm{C}$-TFA as both ${ }^{14} \mathrm{CO}_{2}$ (127 \pm 38 percent; fig. $4 \mathrm{a}$ ) and ${ }^{14} \mathrm{CH}_{4}(3.1 \pm 0.5$ percent; fig. $4 \mathrm{c})$. The liquid phase of slurries amended with $1 \mu \mathrm{Ci}$ 2-14C-TFA were assayed for soluble radiolabeled products. Figure 4(d) shows that TFA was sequentially reduced to DFA, MFA and acetate. While TFA was degraded in these nitrate-amended slurries, a prolonged incubation was required before gaseous and liquidphase degradation products of TFA were observed. Figure 4(b) shows that production of nitrous oxide ceased after 7 days, after which TFA degradation commenced. It is likely that TFA degradation in this experiment was inhibited by nitrogen oxides produced during bacterial nitrate-respiration. Methanogenesis is inhibited by nitrogen oxides (Balderston and Payne, 1976), and this may account for the absence of both methanogenesis and TFA degradation that we observed while nitrous oxide was prasent in our samples. In these experiments $30 \pm$ percent of the $1 \mu \mathrm{Ci} 2-{ }^{14} \mathrm{C}$-TFA was converted to ${ }^{14} \mathrm{CH}_{4}$ and $75 \pm$ percent to ${ }^{14} \mathrm{CO}_{2}$. The large quantity of ${ }^{14} \mathrm{CO}_{2}$ implies oxidation of the methyl group by an unidentified electron acceptor, possibly $\mathrm{Fe}(\mathrm{III}), \mathrm{Mn}(\mathrm{IV})$, or $\mathrm{SO}_{4}{ }^{2-}$ formed by reaction of reduced forms with nitrogen oxides. 
Degradation of TFA in sediments amended with other electron acceptors. Slurries of sediments collected in May, 1995 were amended with $20 \mathrm{mmol} / \mathrm{L} \mathrm{MnO}_{2}$ to elicit TFA degradation by manganese-reducing bacteria, or $10 \mathrm{mmol} / \mathrm{L} \mathrm{Fe}$ (III)NTA to elicit TFA degradation by iron-reducing bacteria. Figure 5 shows that neither ${ }^{14} \mathrm{CH}_{4}$ nor ${ }^{14} \mathrm{CO}_{2}$ were produced from ${ }^{14} \mathrm{C}$-TFA. Liquid phase products were not detected under any of these conditions. Sulfate was added to slurries on several occasions but did not elicit TFA degradation (fig. 5, 8-14, 17, 18)

Degradation of 2.14 C-TFA vs. 1.14 C-TFA. In selected experiments the position of the radiolabeled carbon was varied using $1-{ }^{14} \mathrm{C}$-TFA or $2-14 \mathrm{C}$-TFA. This was done to determine if the carboxyl group of $1-14 \mathrm{C}$-TFA was oxidized to carbon dioxide und $9 \mathrm{r}$ methanogenic or sulfate-reducing conditions (fig. 12-14). However, neither ${ }^{1-14} \mathrm{C}$-TFA or $2-{ }^{14} \mathrm{C}$-TFA were degraded in the sediments studied.

Degradation of TFA in anaerobic sediments plus hydrogen. An experiment was designed to determine the effect of hydrogen gas addition to the saltmarsh slurries with, and without added sulfate. Figure 14 shows that, while the samples amended with hydrogen gas stimulated $\mathrm{CH}_{4}$ production compared to samples incubated under nitrogen, 2-14 C-TFA was not degraded to gaseous products under either hydrogen or nitrogen atmospheres.

Degradation of TFA using various TFA concentrations. The concentration of ${ }^{14} \mathrm{C}$-TFA was varied in several experiments to observe whether the concentration of TFA was a critical factor in the diminished TFA degradation at higher concentrations of TFA (for example, Visscher and others, 1994; and fig. 4). The experiment shown in figure 4 used a range of $2-{ }^{14} \mathrm{C}$-TFA concentrations from $0.15 \mu \mathrm{M}$ to $1.5 \mu \mathrm{M}$. Generally, more ${ }^{14} \mathrm{C}_{4}$ and ${ }^{14} \mathrm{CO}_{2}$ was produced in $0.9 \mu \mathrm{M} 2-{ }^{14} \mathrm{C}$-TFA amended sediments than those with 1.5 $\mu \mathrm{M} 2-14 \mathrm{C}$-TFA. Another experiment was conducted with sediments collected in June, 1995 with varying amounts $\left(0.5\right.$ to $1 \mu \mathrm{Ci}$ ) of $2-{ }^{14} \mathrm{C}$-TFA (fig. 15$)$. No radiolabeled gas phase or liquid phase products were observed. The concentration of $2-14 \mathrm{C}$-TFA did not appear to inhibit methane production in these sediments.

Degradation of TFA in sediments amended with various electron donors. Experiments were designed to determine if various electron donors would stimulate TFA degradation in saltmarsh slurries. These included amendment with lactate, pyruvate, glucose, oxalate, propionate, and benzoate. While all additions stimulated methane production in the sediments, none of the additions stimulated production of ${ }^{14} \mathrm{CH}_{4}$ or ${ }^{14} \mathrm{CO}_{2}$ (fig. 16). Other electron donors were added to experiments throughout the course of this stud $\%$ TMA (fig. 5 and 18) and acetate (fig. 19 and 20) did not stimulate degradation of $2-14 \mathrm{C}$ TFA, although these amendments enhanced $\mathrm{CH}_{4}$ and $\mathrm{CO}_{2}$ production over unamer fed controls.

Degradation of TFA in nitrogen-amended sediments. Sediment slurries were amended with ammonium chloride to determine if the sediments were nitrogen limited, which 
might cause loss of TFA-degradation activity. Slurries amended with $0.1 \mathrm{mM} \mathrm{NH}_{A} \mathrm{Cl}$, with and without $10 \mathrm{mM}$ sulfate, did not degrade 2-14C-TFA (fig. 19).

\section{Degradation of TFA in sediments pre-incubated with fluorinated acetates. To} determine if TFA degradation could be induced, sediments were pre-incubated with unlabeled fluorinated acetates prior to the addition of 2-14C-TFA. The pre-incubation of sediments with fluorinated acetates did not elicit degradation of $2-{ }^{14} \mathrm{C}$-TFA and no radiolabeled products were detected in either the gas or liquid phase (fig. 20).

Degradation of TFA in sediments collected from Bolinas Bay, Calif. In an effort to see whether estuarine sediments from a site other than the San Francisco saltmarsh conld degrade TFA, sediments were collected from a mudflat in Bolinas Bay, near Stinson Beach, Calif. These sediments were collected from two sites (south and north loce ${ }^{*}$ ions) of the mudflats in May, 1995. The sediments collected from both sites were slurried with or without sulfate or TMA. Fig.s 21 and 22 show that, while the TMA-amended slirries from both sites produced greater quantities of methane than sediments without TMA, none of the slurries produced ${ }^{14} \mathrm{CH}_{4}$ or ${ }^{14} \mathrm{CO}_{2}$. Liquid samples from these sediments did not show ${ }^{14} \mathrm{C}$-labeled intermediates (data not shown).

\section{Experiments With Freshwater Sediments}

Sediments collected from Searsville Lake in October of 1993 were methanngenic and degraded $1.85 \mu \mathrm{Ci} 2-{ }^{14} \mathrm{C}$-TFA to ${ }^{14} \mathrm{CH}_{4}$, via ${ }^{14} \mathrm{C}$-labeled intermediates (fig. 23 ). In this same experiment, slurries with both inhibitors (molybdate and BES) did not degrade 2- ${ }^{14} \mathrm{C}$-TFA, while those with molybdate produced ${ }^{14} \mathrm{C}$-intermediates and ${ }^{14} \mathrm{CH}_{4}$ (data shown in Visscher et al., 1994). Sediments collected three months later were also able to degrade ${ }^{14} \mathrm{C}$-TFA to ${ }^{14} \mathrm{CH}_{4}$ and ${ }^{14} \mathrm{CO}_{2}$ under methanogenic and sulfate-reducing conditions, respectively, but not under nitrate-reducing conditions (Visscher and others, 1994).

However, slurries from sediments collected in January, 1995 did not produce ${ }^{14} \mathrm{CH}_{4}$ or ${ }^{14} \mathrm{CO}_{2}$ (fig. 24) from either $1-{ }^{14} \mathrm{C}$-TFA or $2-14 \mathrm{C}$-TFA. These sediments were re-assayed in May of 1995. Once again, sediments did not produce gaseous or liquidphase degradation products from 2-14C-TFA under methanogenic, sulfate-reducing, or nitrate-respiring conditions (fig. 25). A final experiment was made in August, 1995 with fresh material. No activity was detected under aerobic, methanogenic or sulfate-reducing conditions (fig. 26).

\section{Experiments With Sacramento Delta Peat Soil}

Soil samples, collected in April, 1994, were slurried anaerobically and amended with $20 \mathrm{mM}$ nitrate and either $4 \mu \mathrm{Ci}$ or $10.2 \mu \mathrm{Ci} 2-{ }^{14} \mathrm{C}$-TFA. Soils given $4 \mu \mathrm{Ci} 2-{ }^{14} \mathrm{C}$ TFA converted $0.51 \pm 0.05$ percent of the $2-{ }^{14} \mathrm{C}$-TFA to ${ }^{14} \mathrm{CO}_{2}$, while those amerted 
with the higher concentration degraded $0.42 \pm 0.01$ percent to ${ }^{14} \mathrm{CO}_{2}$ (fig. 27). Autoclaved controls did not degrade $2-{ }^{14} \mathrm{C}$-TFA. Liquid-phase samples were not analyzed for soluble intermediates. Slurries from this same sediment were again ma de in May, 1994 under aerobic conditions. None of these slurries produced ${ }^{14} \mathrm{CO}_{2}$, even after acidification of the samples (data not shown).

Soils were again collected from the same site in August, 1995 and assayed for TFA degradation under methanotrophic conditions. Sediments were amended with $\mathrm{O}_{2}$ and $\mathrm{CH}_{4}$ and $2-{ }^{14} \mathrm{C}$-TFA. Figure 28 shows that TFA was not degraded to ${ }^{14} \mathrm{CO}_{2}$ in this experiment.

\section{Experiments With Forest Soil}

Soils from the Hubbard Brook Experimental Forest were collected in June and July of 1995. Studies concerning the fate and transport of unlabeled TFA were ongoing at the site since May, 1994. After four months these researchers observed a 100 percent loss of TFA in the system (S. Tartowski, oral comm.). Several soil slurry experiments were done with these soils to determine if the TFA loss was due to microbial degradatior. Figures 29-32 show that none of the soil slurries were able to significantly degrade ${ }^{14} \mathrm{C}$ TFA to ${ }^{14} \mathrm{CH}_{4}$ or liquid phase products, after anaerobic or aerobic incubations. However, we did observe trace $(0.1 \mathrm{nCi} / 0.25 \mathrm{~mL},<1$ percent $)$ amounts of ${ }^{14} \mathrm{CO}_{2}$ during gas rhase sampling of the slurries but it was no longer detectable after $24 \mathrm{~h}$ of incubation. Slu ties incubated aerobically with $\mathrm{CH}_{4}$ demonstrated methane-oxidation activity (fig. 33). However, ${ }^{14} \mathrm{CO}_{2}$ was not produced from $2-{ }^{14} \mathrm{C}$-TFA (fig. $33 \mathrm{~b}$ ).

Slurries were amended with various electron acceptors (sulfate, nitrate, $\mathrm{FeO} \mathrm{OH}$ ) to determine if these elicited reducing conditions favored by microorganisms capable of degrading TFA. However, $2-14 \mathrm{C}$-TFA did not decrease under any of these conditions (fig. 34-36) (liquid phase data not shown). ${ }^{14} \mathrm{CO}_{2}$ was again observed in trace amo ints but did not accumulate to significant levels. TFA degradation was also studied in forest soil slurries amended with acetate. Figure 36 shows that anaerobic, acetate-amender slurries did not produce either ${ }^{14} \mathrm{CO}_{2}$ or ${ }^{14} \mathrm{CH}_{4}$ from $2-{ }^{14} \mathrm{C}$-TFA.

Liquid phase samples taken at the end of each experiment described did not reveal the presence of radiolabeled intermediates (data not shown). Additionally, ${ }^{14} \mathrm{C}$-TFA levels did not decrease significantly with time (data not shown).

In light of the acidic conditions of the forest soils ( $\mathrm{pH}$ ca. 4.5), an experimert was designed to buffer the slurries at neutral $\mathrm{pH}$ to determine if this condition would enhance TFA-degradation. The anaerobic, phosphate-buffered slurries had a pH of ca. 6.5-7. However, they did not degrade 2- 14 C-TFA to gaseous products (fig. 35 ) or liquid-phase products (data not shown). 


\section{Experiments With Small Cores From Estuarine Sediments}

Sediment sub-cores were taken to determine if undisturbed soil or sediment could degrade $2-14$ C-TFA. Figures $37-40$ show that none of the samples degraded $2-14 \mathrm{C}$-TFA to gaseous products. In one of the core experiments, sulfate, TMA, or oxygen were added to the samples to determine if these elicited TFA degradation. However, none of the samples with these additions degraded $2-14$ C-TFA to gaseous products (fig. 39). None of these experiments were assayed for liquid-phase radiolabeled products.

\section{Experiments With Bacterial Cultures}

Several pure cultures of bacteria were studied for their ability to degrade TFA during growth on acetate. Cultures were first assayed for inhibition by non-radiolabeled TFA during growth on acetate, statically at $28^{\circ} \mathrm{C}$. Figure 41 shows that the growth of Methanosarcina mazei S- 6 and Desulfobacter curvatus were not inhibited by TFA concentrations from 0-1 mM. None of the bacteria studied exhibited inhibition by unlabeled TFA during growth on acetate. Subsequent to the inhibition studies, each bacterial culture was studied for the ability to degrade $2-{ }^{14} \mathrm{C}$-TFA. Figure 42 shows that $2-14$ C-TFA was not degraded by growing, acetate-fed cultures of $M$. mazei S-6. There results are representative of all cultures studied because none of the cultures were able to degrade $2-14$ C-TFA. 


\section{CONCLUSIONS}

TFA was shown to be degraded in experiments conducted by our laboratory with saltmarsh and freshwater sediments collected from October 1993 to June 1994. In their 1994 publication, Visscher and others reported some of these findings. These authors showed that degradation of ${ }^{14} \mathrm{C}$-TFA was the result of bacterial activity and that it occurred under both oxic and anoxic conditions. In addition, these workers showed that ${ }^{14} \mathrm{C}$-TFA was reductively defluorinated under methanogenic conditions to acetate, which was then metabolized by methanogens to methane.

Our results, described here, show that ${ }^{14} \mathrm{C}$-TFA is also reductively defluorinated under sulfate-reducing conditions (fig. 3). Visscher and others (1994) and our results show that ${ }^{14}$ C-TFA was sequentially defluorinated to DFA, MFA and acetate (fig. 3b), and the methyl group of the acetate was then oxidized to carbon dioxide (fig. $3 \mathrm{a}$ ). It is not known whether methanogens and/or sulfate-reducing bacteria directly reductively defluorinate TFA, however it appears that both are involved in the metabolism of th: resulting acetate.

Our further attempts to explore the microbial ecology of TFA degradation have been unsuccessful due to the inability of sediments collected from several sites, including those with prior TFA-degradation activity, to degrade ${ }^{14} \mathrm{C}$-TFA. Although we were able to show repeated degradation of ${ }^{14} \mathrm{C}$-TFA to ${ }^{14} \mathrm{CH}_{4},{ }^{14} \mathrm{CO}_{2}$, and liquid phase products prior to December, 1994, experiments conducted since that time have not shown TFA degradation.

Since the loss of TFA-degrading activity, a variety of redox conditions have been studied including methanogenic, sulfate-reducing, nitrate-respiring, iron-reducing, manganese-reducing, and aerobic conditions. Due to our prior observations that TFA was degraded in repeated experiments under methanogenic and sulfate-reducing conditions, we tested these conditions with monthly samples from the South San Francisco Bay saltmarsh. In addition, these conditions were tested with other saltmarsh sites and the freshwater site. All samples from these sites, slurried and incubated anaerobically, v'ere methanogenic (fig. 5-20) but did not degrade TFA. It seems likely that we would have encountered TFA degradation in these samples, similar to that observed in samples taken prior to December 1994, if the organisms responsible were from the general methanogenic or sulfate-reducer populations. These results suggest that the organisms responsible for TFA degradation were specialized members of these populations.

In addition, various electron donors have been studied for their ability to elicit TFA-degrading microorganisms in anaerobic sediment slurries. These experiments were conducted to determine if bacterial cometabolism of these substrates elicited TFA degradation. None of these conditions elicited TFA degradation in the saltmarsh or freshwater sediments. Although all of these sediments produced methane, none of the electron donor additions elicited TFA degradation. 
Visscher and others, 1994, showed that TFA degradation could be inhibited at concentrations greater than $1.85 \mu \mathrm{M}$. Our results also show slurries amended with $0.9 \mu \mathrm{M}$ $2-{ }^{14} \mathrm{C}$-TFA yielded three times the amount of ${ }^{14} \mathrm{CH}_{4}$ than slurries with $1.5 \mu \mathrm{M}$ (fig. 4). Our subsequent experiments used amounts of TFA well within the range of noninhibiting concentrations $(0.15$ to $1.7 \mu \mathrm{M})$; therefore the lack of TFA degradation in these studies was not a result of inhibition by TFA.

To determine if specific, inducible enzymes were involved in TFA degradation, pre-incubation with fluorinated acetates was used as a means to induce TFA degradation in the soils and sediments. However this experiment was unsuccessful since none of the pre-incubated sediments were able to degrade TFA to gas phase products. These results indicate that prior exposure of the sediments to TFA, or fluorinated analogs of TFA, does not elicit TFA degradation by sediment microflora. However, these sediments were $\mathrm{F}^{-} \mathrm{e}-$ exposed for a relatively short time ( 1 month) and it remains possible that longer expc sure times may elicit TFA degradation.

While we did observe a small amount of ${ }^{14} \mathrm{CO}_{2}$ production in the northeastern hardwood forest soils, the ${ }^{14} \mathrm{CO}_{2}$ was transient and did not accumulate. These result: may be due to a very low conversion of ${ }^{14} \mathrm{C}$-TFA to ${ }^{14} \mathrm{CO}_{2}$, which then disappeared from the gas phase, possibly by partitioning into organic material. Production of ${ }^{14} \mathrm{C}_{2}$ in these soils seemed to occur mostly under anaerobic conditions but was not enhanced by addition of acetate, nitrate, sulfate, or ferric iron. The inability of our efforts to consistently reproduce ${ }^{14} \mathrm{CO}_{2}$ production, or observe ${ }^{14} \mathrm{CO}_{2}$ accumulation, does not allow us to make conclusions about TFA degradation in these soils. It does remain a possible explanation for the loss of TFA observed in the seep, but cannot be proved ty our results.

The fact that saltmarsh and freshwater sediments capable of TFA degradation became inactive suggests that this activity is not a normal occurrence in these ecosystems and is the result of either a rare circumstance favoring TFA-degrading microorganisms, or is a routine condition that was lost because of unusually high precipitation occurring during the winter months of 1994-95. However, the latter explanation seems improbable due to the fact that repeated sampling during our studies encompassed a sufficient time period for observation of conditions similar to those prior to this precipitation. Thus, we conclude that our previous results were the result of specialized, and maybe somewhat rare, microorganisms and that TFA is generally recalcitrant to biological degradation. 


\section{References Cited}

Balderston, W.L., and Payne, W.J., 1976, Inhibition of methanogenesis in salt march sediments and whole-cell suspensions of methanogenic bacteria by nitroger oxides: Applied and Environmental Microbiology, v. 32, p. 264-269.

Boone, D.R., Johnson, R.L., and Liu, Y., 1989, Diffusion of the interspecies electron carriers $\mathrm{H}_{2}$ and formate in methanogenic ecosystems and its implications ir the measurement of $\mathrm{K}_{\mathrm{m}}$ for $\mathrm{H}_{2}$ or formate uptake: Applied and Environmental Microbiology, v. 55, p. 1735-1741.

Calver, M.C., and King, D.R., 1986, Controlling vertebrate pests with fluoroacetate: lessons in wildlife management, bio-ethics and co-evolution: Journal of Biological Education, v. 20, p. 257-262.

Chumley, F.G., 1992, Current Status of Research on Environmental Fate and Impact of Trifluoroacetic Acid (TFA): Alternative Fluorocarbons Environmental Acceptability Study (AFEAS).

Culbertson, C.W., Strohmaier, F.E., and Oremland, R.S., 1988, Acetylene as a subrtrate in the development of primordial bacterial communities: Origins Life Evol. Biosphere, v. 18, p. 397-407.

Culbertson, C.W., Zehnder, A.J.B., and Oremland, R.S., 1981, Anaerobic oxidation of acetylene by estuarine sediments and enrichment cultures: Applied and Environmental Microbiology, v. 41, p. 396-403.

DeWeerd, K.A., Mandelco, L., Tanner, R.S., Woese, C.R., and Suflita, J.M., 1990, Desulfomonile tiedjei gen. nov. and sp. nov., a novel anaerobic, dehalogena+ing, sulfate-reducing bacterium: Archives of Microbiology, v. 154, p. 23-30.

Egli, C., Tschan, T., Scholtz, R., Cook, A.M., and Leisinger, T., 1988, Transformation of tetrachloromethane to dichloromethane and carbon dioxide by Acetobacterium woodii: Applied and Environmental Microbiology, v. 54, p. 2819-2824.

Franklin, J., 1993, The atmospheric degradation and impact of 1,1,1,2-tetrafluoroet'ane (hydrofluorocarbon 134a): Chemosphere, v. 27, p. 1565-1601.

Hirsch, P., and Alexander, M., 1960, Microbial consumption of halogenated propic nic and acetic acids: Canadian Journal of Microbiology, v. 6, p. 241-249.

Lovley, D.R., Giovannoni, S.J., White, D.C., Champine, J.E., Phillips, E.J.P., Gorby, Y.A., and Goodwin, S., 1993, Geobacter metallireducens gen. nov. sp. nov., a microorganism capable of coupling the complete oxidation of organic comf unds 
to the reduction of iron and other metals: Archives of Microbiology, v. 159, p. 336-344.

Lovley, D.R., and Phillips, E.J.P., 1988, Novel mode of microbial metabolism: organic carbon oxidation coupled to dissimilatory reduction of iron or mangenese: Applied and Environmental Microbiology, v. 54, p. 1472-1480.

Oremland, R.S., and Capone, D.G., 1988, Use of "specific" inhibitors in biogeochenistry and microbial ecology: Advanced Microbial Ecology, v. 10, p. 285-383.

Oremland, R.S., and Culbertson, C.W., 1992, Evaluation of methyl fluoride and dirnethyl ether as inhibitors of aerobic methane oxidation: Applied and Environmental Microbiology, v. 58, p. 2983-2992.

Oremland, R.S., Marsh, L.M., and Polcin, S., 1982, Methane production and simultaneous sulfate reduction in anoxic saltmarsh sediments: Nature, v. 29? p. 143-145.

Oremland, R.S., and Polcin, S.P., 1982, Methanogenesis and sulfate reduction: competitive and noncompetitive substrates in estuarine environments: Applied and Environmental Microbiology, v. 44, p. 1270-1276.

Pfennig, N., and Biebl, H., 1976, Desulfuromonas acetoxidans gen. nov. and sp. nov., a new anaerobic, sulfur-reducing, acetate-oxidizing bacterium: Archives of Microbiology, v. 110, p. 3-12.

Rusch, G.M., 1994, Toxicity of Trifluoroacetic Acid, in Chumley, F.G., ed., AFEAS Workshop on the Environmental Fate of Trifluoroacetic Acid: Alternative Fluorocarbons Environmental Acceptability Study (AFEAS), Washington, I.C. 302 p.

Smith, R.L., and Oremland, R.S., 1983, Anaerobic oxalate degradation: widespread natural occurrence in aquatic sediments: Applied and Environmental Microbiology, v. 46, p. 106-113.

Thompson, R.S., 1994, Effects of TFA on Algae and Higher Plants, in Chumley, F.G., ed., AFEAS Workshop on the Environmental Fate of Trifluoroacetic Acid: Alternative Fluorocarbons Environmental Acceptability Study (AFEAS), Washington, D.C. 302 p.

Tromp, T.K., Ko, M.K.W., Rodriguez, J.M., and Sze, N.D., 1995, Potential accumulation of a CFC-replacement degradation product in seasonal wetlands: Nature, v. 376, p. 327-330. 
Visscher, P.T., Culbertson, C.W., and Oremland, R.S., 1994, Degradation of trifluoroacetate in oxic and anoxic sediments: Nature, v. 369, p. 729-731.

Wallington, T.J., Schneider, W.F., Worsnop, D.R., Nielsen, O.J., Sehested, J., Debruyn, W.J., and Shorter, J.A., 1994, ES\&T Feature: The environmental impact of CFC replacements - HFCs and HCFCs: Environmental Science \& Technology, v. 28, p. 320A-326A.

Widdel, F., 1987, New types of acetate-oxidizing, sulfate-reducing Desulfobacter species, $D$. hydrogenophilus sp. nov., $D$. lactus sp. nov., and $D$. curvatus sp. nov.: Archives of Microbiology, v. 148, p. 286-291.

Widdel, F., and Pfennig, N., 1984, Dissimilatory sulfate- or sulfur-reducing bacteric. in Krieg, N.R., and Holt, J.G., eds., Bergey's Manual of Systematic Bacteriology: Baltimore, Williams \& Wilkins, pp. 663-679.

Wilson, E., 1995, CFC Substitute Degradation Product May Harm Some Ecosysterc: Chemical \& Engineering News, p. 4.

Yavitt, J.B., and Fahey, T.B, 1993, Production of methane and nitrous oxide by organic soils within a northern hardwood forest ecosystem, in Oremland, R.S., ed., Biogeochemistry of Global Change: Radiatively Active Trace Gases: New York, Chapman Hall, pp. 261-277. 

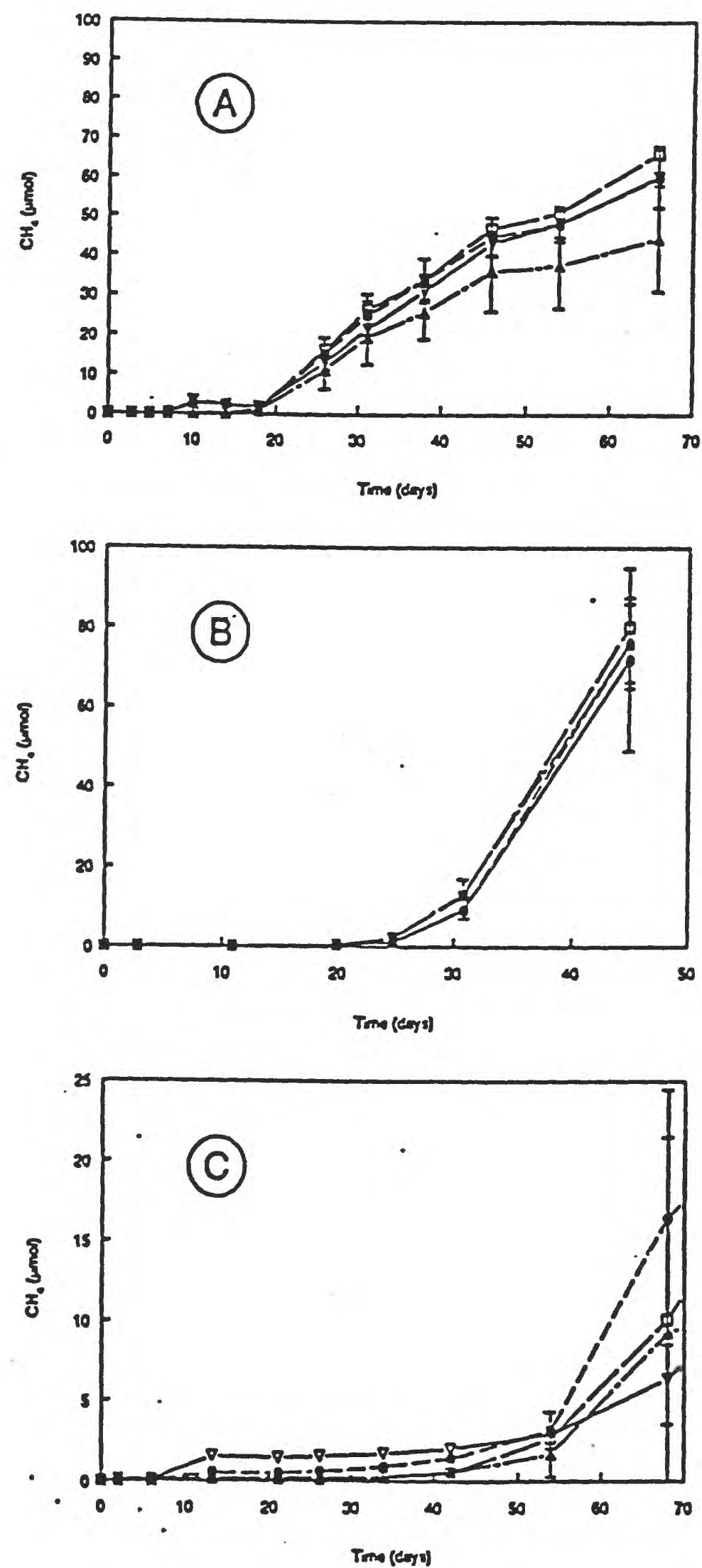

Figure 1. Methanogenesis in anaerobic South San Franciseo Bay saltnarsh slurries, from January through Mareh 1994, with varying (A) TFA additions. (B) DFA additions, and (C) MFA additions. Symbols: ( $\nabla) \mathrm{CH}_{4}$ for unamended samples $(\theta)$ slumies amended with $0.1 \mu M$ TFA, DFA, or MFA; (A) slurries amended with I $\mu M$ Auorinated acetates and (D) amended with $100 \mu \mathrm{ML}$ Symbols represent the mean of three individual slurries and bars indieate \pm 1 standard deviation 


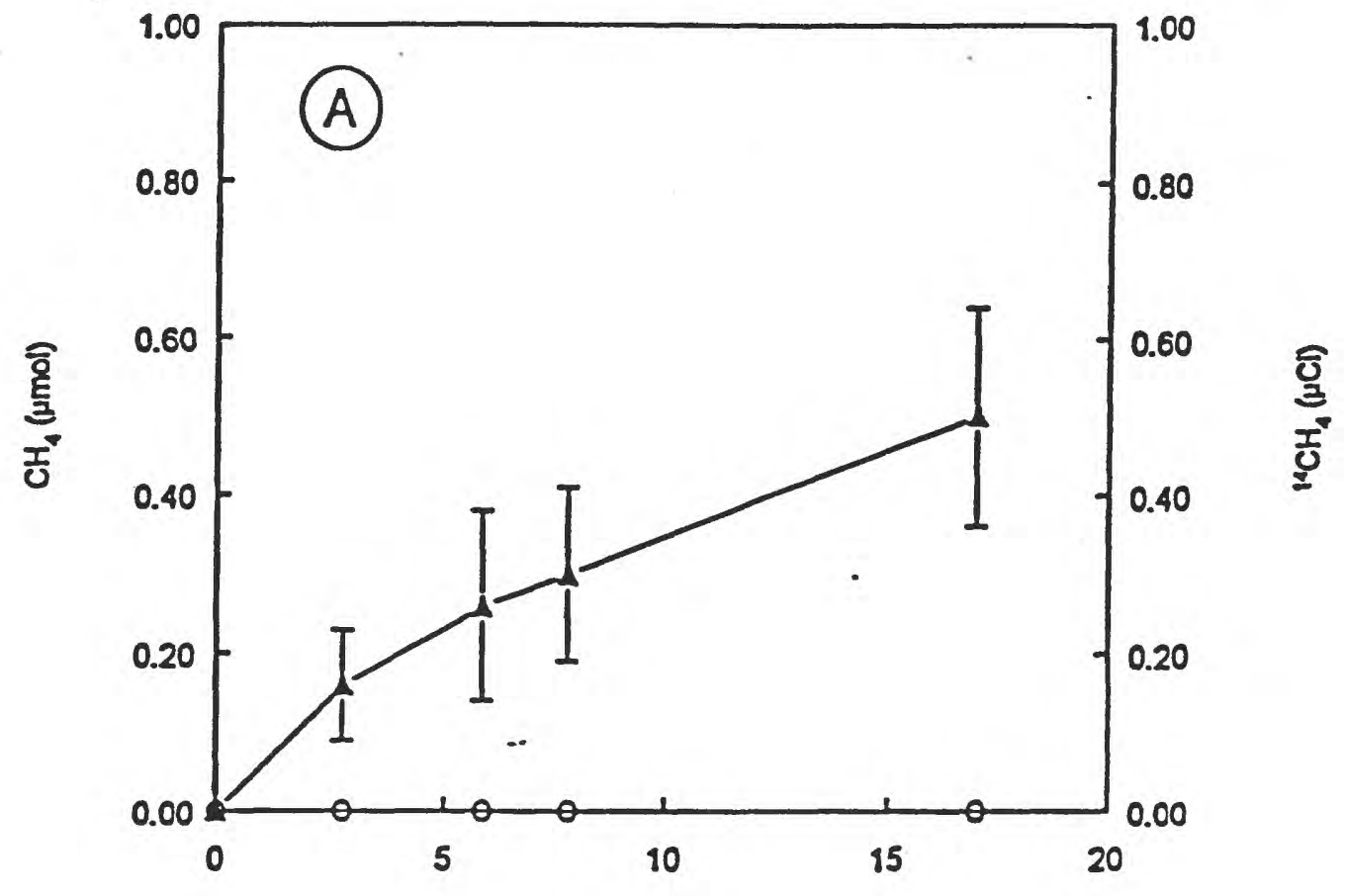

Time (days) ·

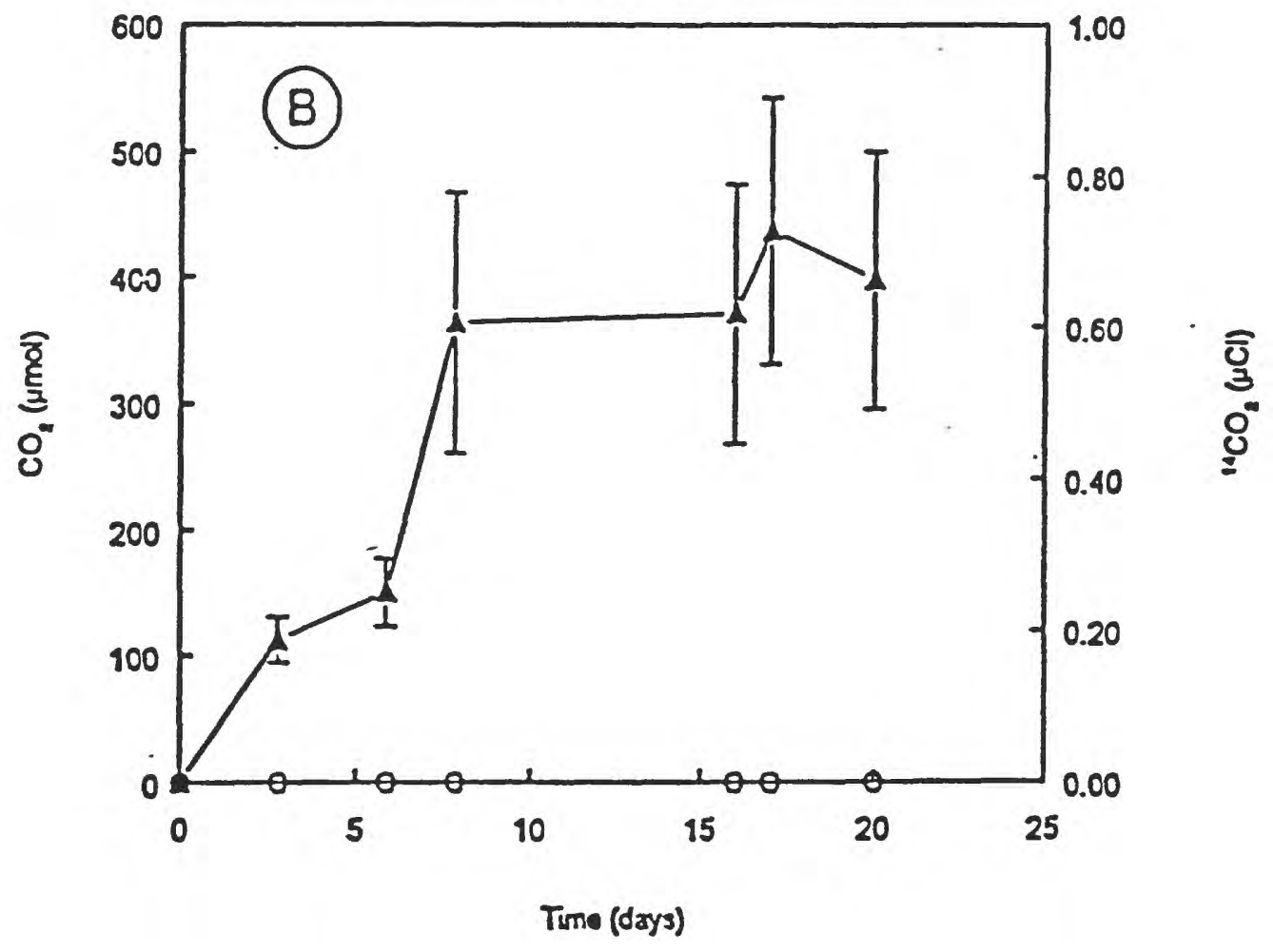

Figure 2. Methanogenesis and $\mathrm{CO}_{2}$ production in anaerobic South $\mathrm{San}$ Franciseo $\mathrm{Bay}$ salumarsh slurries from 41294, amended wich $20 \mathrm{mM}$ sulfate and $0.2 \mu \mathrm{Ci}(0.185 \mu \mathrm{M}) 2 .{ }^{14} \mathrm{C}$-TFA $(A) \mathrm{CH}_{4}$ and ${ }^{14} \mathrm{CH}_{4}$. (B) $\mathrm{CO}_{2}$ and ${ }^{14} \mathrm{CO}_{2}$. Symbols (A) $\mathrm{CH}_{4}$ and $\mathrm{CO}_{2} ;()^{1+} \mathrm{CH}_{4}$ and ${ }^{1+} \mathrm{CO}_{2}$. Symbols represent the mean of three individual slurries and bars indicate \pm 1 seandard deviation. 


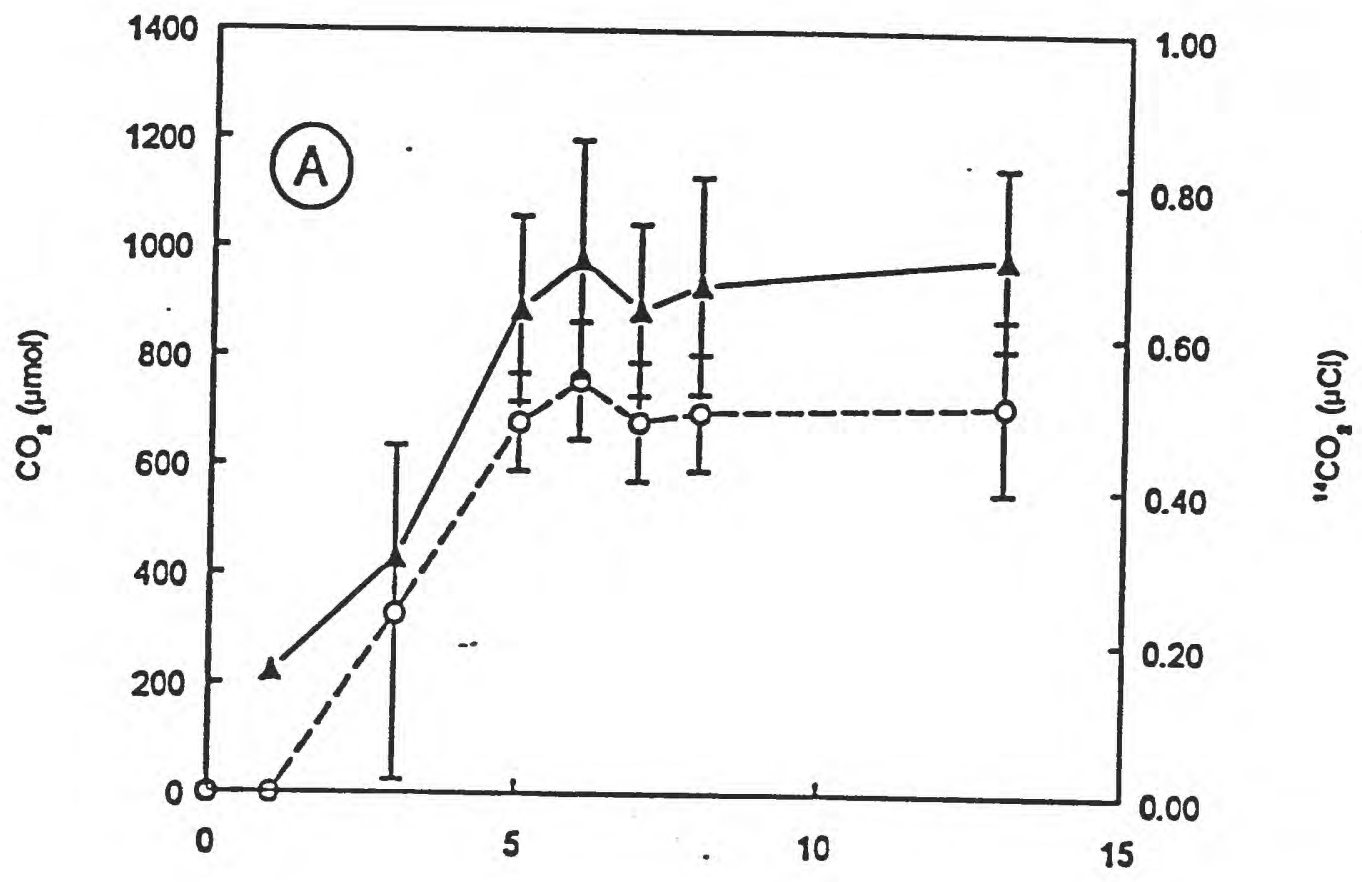

Tumo (days)

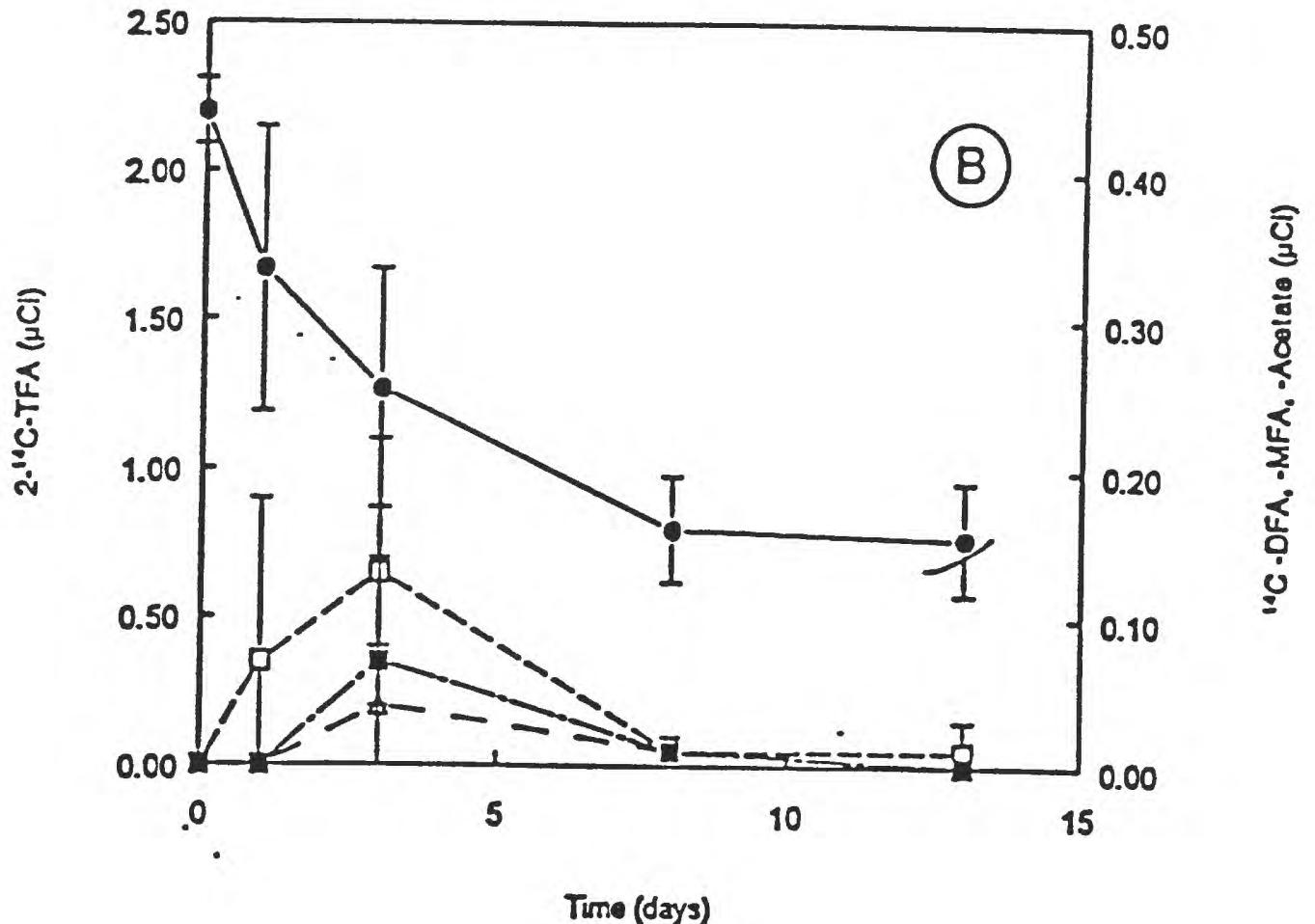

Figure 3. Degradacion of $2 \mu \mathrm{Ci}(1.85 \mu \mathrm{M})$ 2.14 C.TFA in anaerobic South San Francisco Bay saltmasch slurries from 5/11/94 amended with $20 \mathrm{mM}$ sulfate. (A) $\mathrm{CO}_{2}$ and ${ }^{14} \mathrm{CO}_{2}$, (B) disappeanance of $2-14 \mathrm{C}$-TFA and appearance of ${ }^{14} \mathrm{C}$-liquid phase

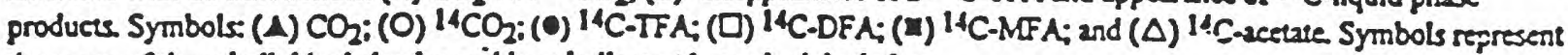
the mean of three individual slurries and bars indicate \pm 1 seandard deviation. 


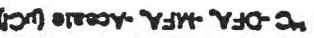
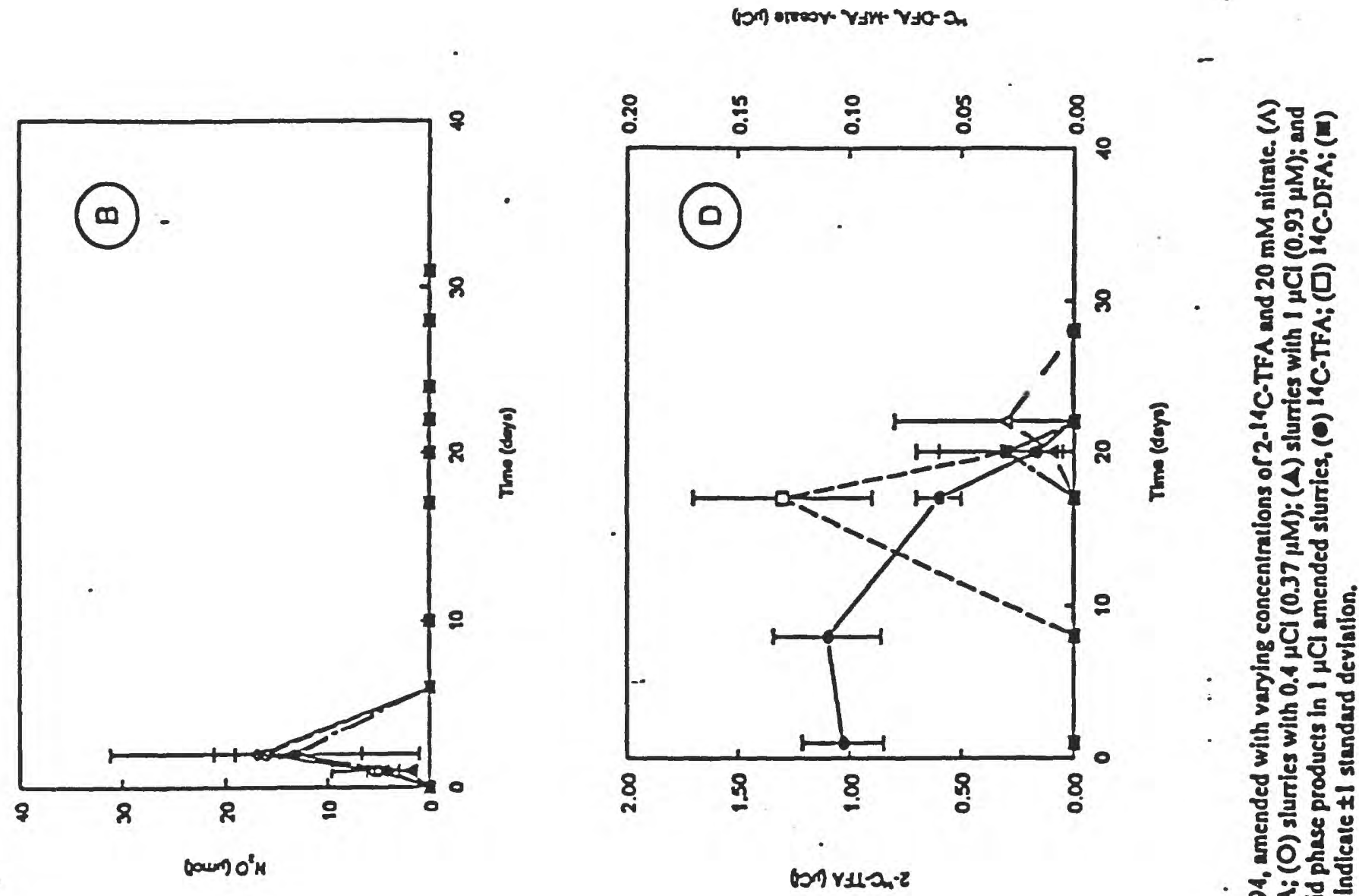

누을
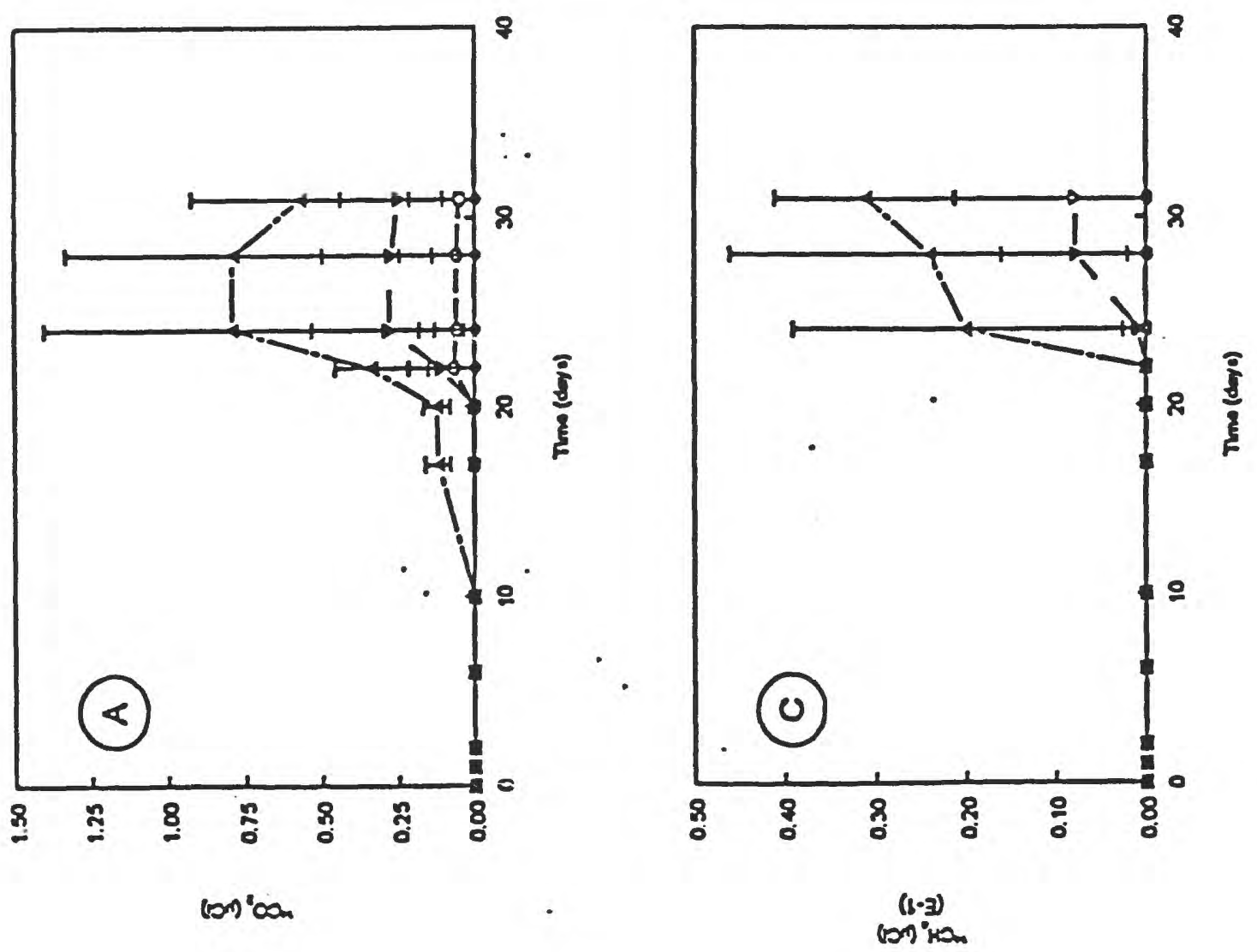

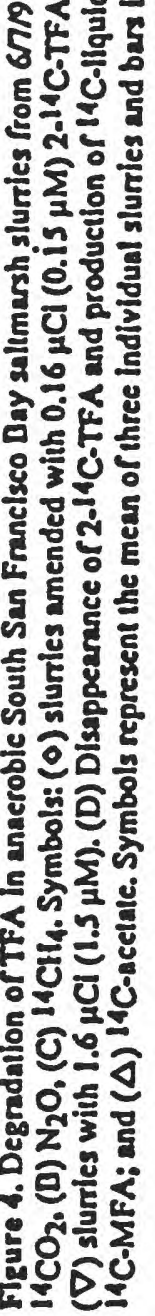



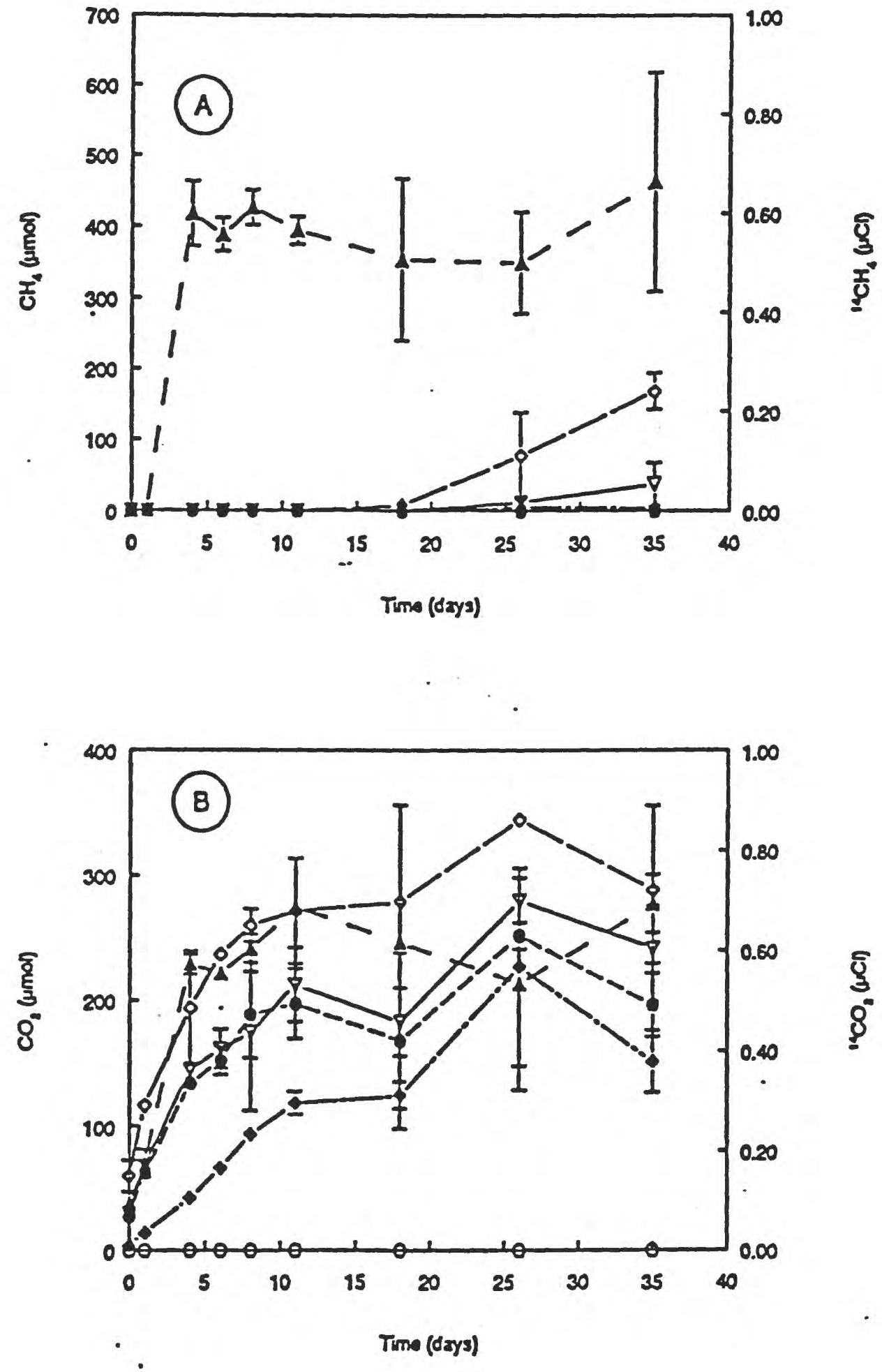

乌్
8

- Figure 3. South San Franeiseo Bay saltmarsh sediments amended with $20 \mathrm{mM}$ sulfate, $20 \mathrm{mM} \mathrm{MnO}, 10 \mathrm{mM}$ FenIIDNTA, or 10 $\mathrm{mM}$ TMU. Sediments collected and slurried anaerobically on $5 / 395$. All received $0.4 \mu \mathrm{Ci}(0.37 \mu \mathrm{M}) 2.14 \mathrm{C}$. TFA. $(A) \mathrm{CH}_{4}$ and

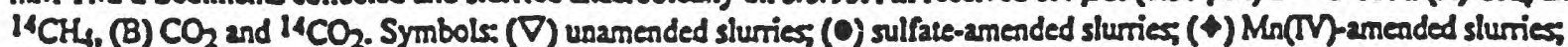

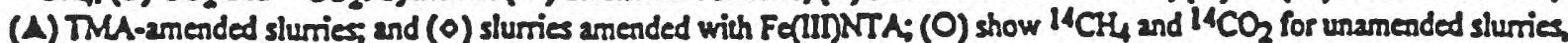
which are representative resulks for all conditions Symbols represent the mean of three individual sluries and bars indieate \pm I standard deviation. 


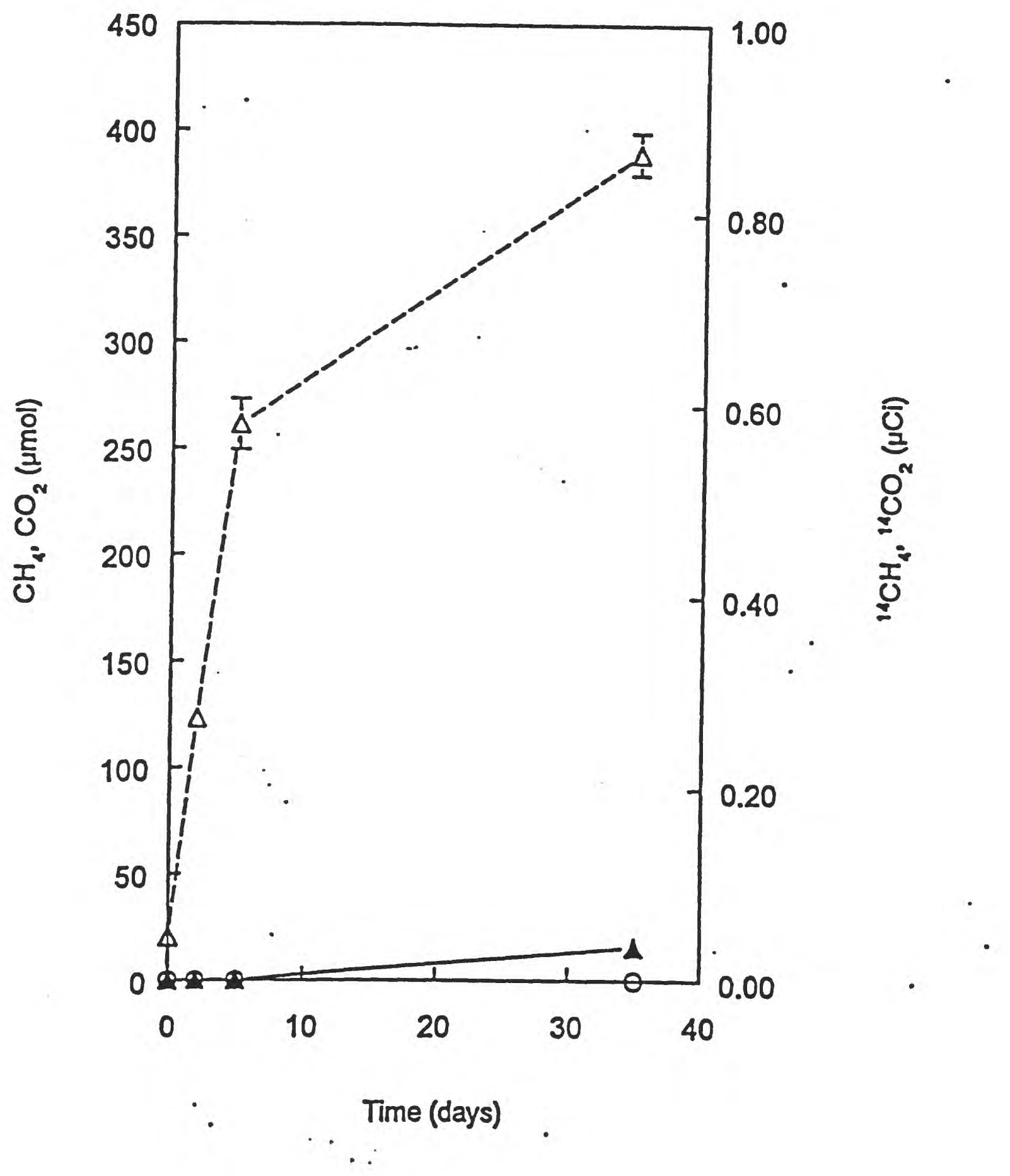

Figure 6. South San Francisco Bay saltmarsh sediment collected and slurried anaerobically on 5/17/95. All slurries received 0.8 $\mu \mathrm{Ci}(0.74 \mu \mathrm{M}) 2.14 \mathrm{C}$.TFA. Symbols: $(\Delta) \mathrm{CH}_{4}:(\Delta) \mathrm{CO}_{2} ;(O){ }^{14} \mathrm{CH}_{4}$ and ${ }^{14} \mathrm{CO}_{2}$. Symbols represent the mean of three individual slumies and bars indicate \pm 1 standard deviation. 


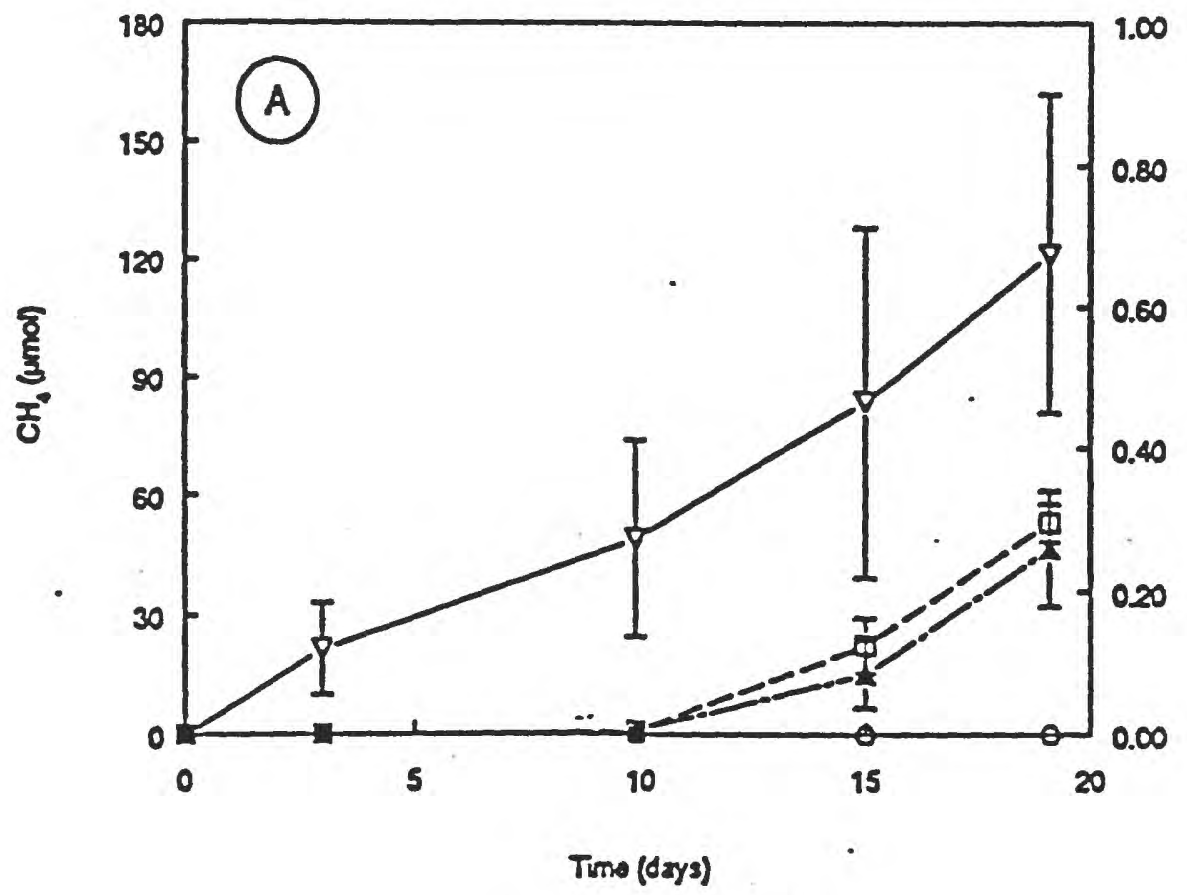

$\frac{9}{3}$

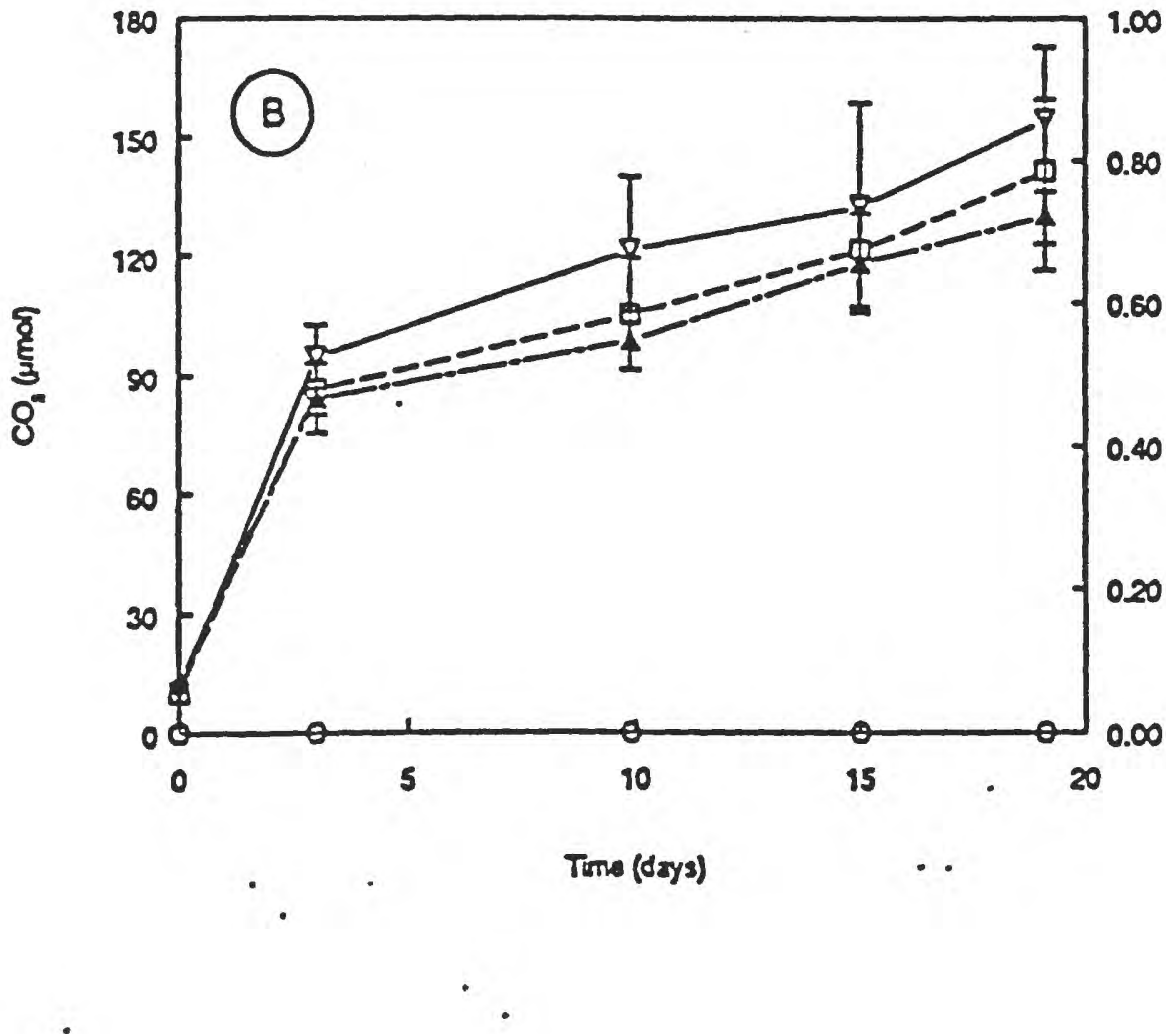

Figure 7. South San Franciseo Bay salumarsh sediment collected and sluried anaerobically on $7113 / 95$. All received $0.91 \mu \mathrm{Ci}$ $(0.84 \mu \mathrm{M}) 2.14 \mathrm{C}$-TFA. (A) $\mathrm{CH}_{4}$ and $14 \mathrm{CH}_{4}$; (B) $\mathrm{CO}_{2}$ and $14 \mathrm{CO}_{2}$. Symbols: (V) $\mathrm{CH}_{4}$ and $\mathrm{CO}_{2}$ in sediments slurried with arificial bay water (ABW); (D) ABW and water collected from the site; $(A)$ slurries with site water only; $(O)^{14} \mathrm{CH}_{4}$ and ${ }^{1} \mathrm{COO}_{2}$ for slurries with ABW, which are representative results for all conditions Symbols represent the meas of three individual sluries and bass indieate \pm 1 sandard deviation. 
$\cos ^{2} \cos$

$\cos ^{\circ} \infty$
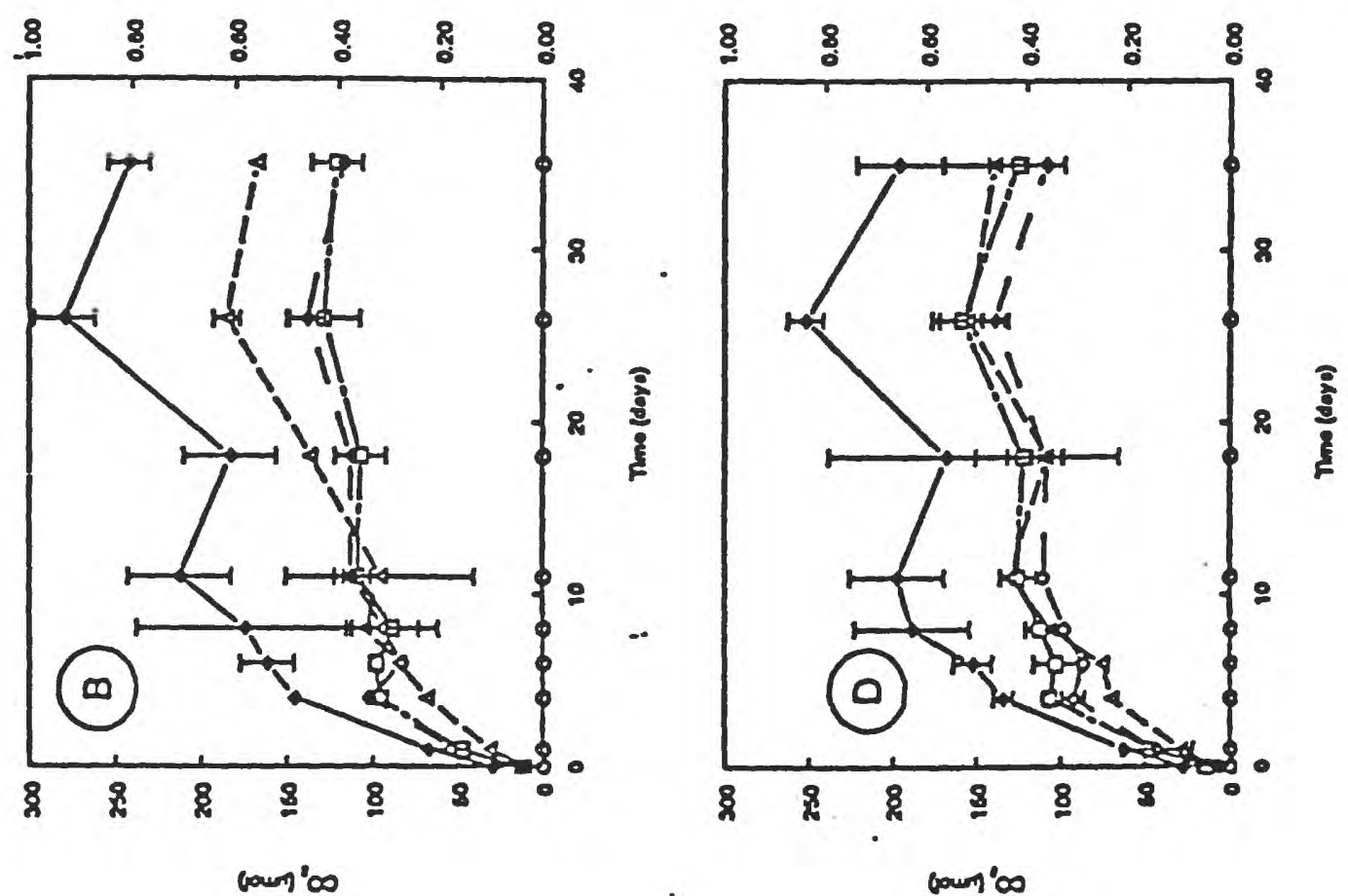

conira

coniva
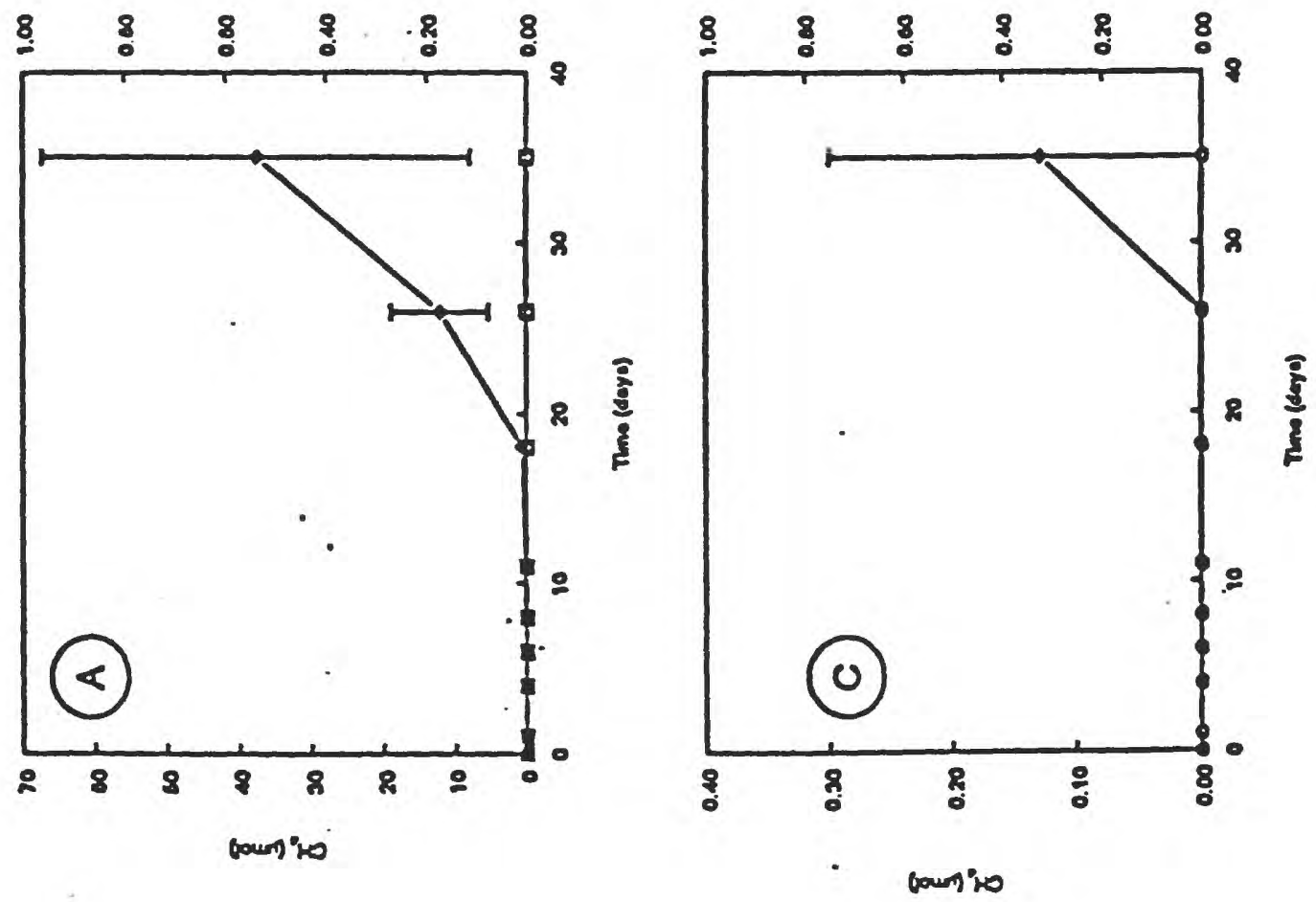

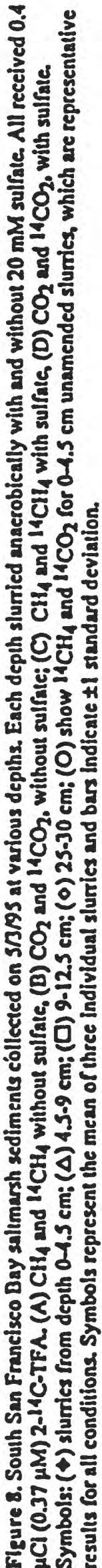




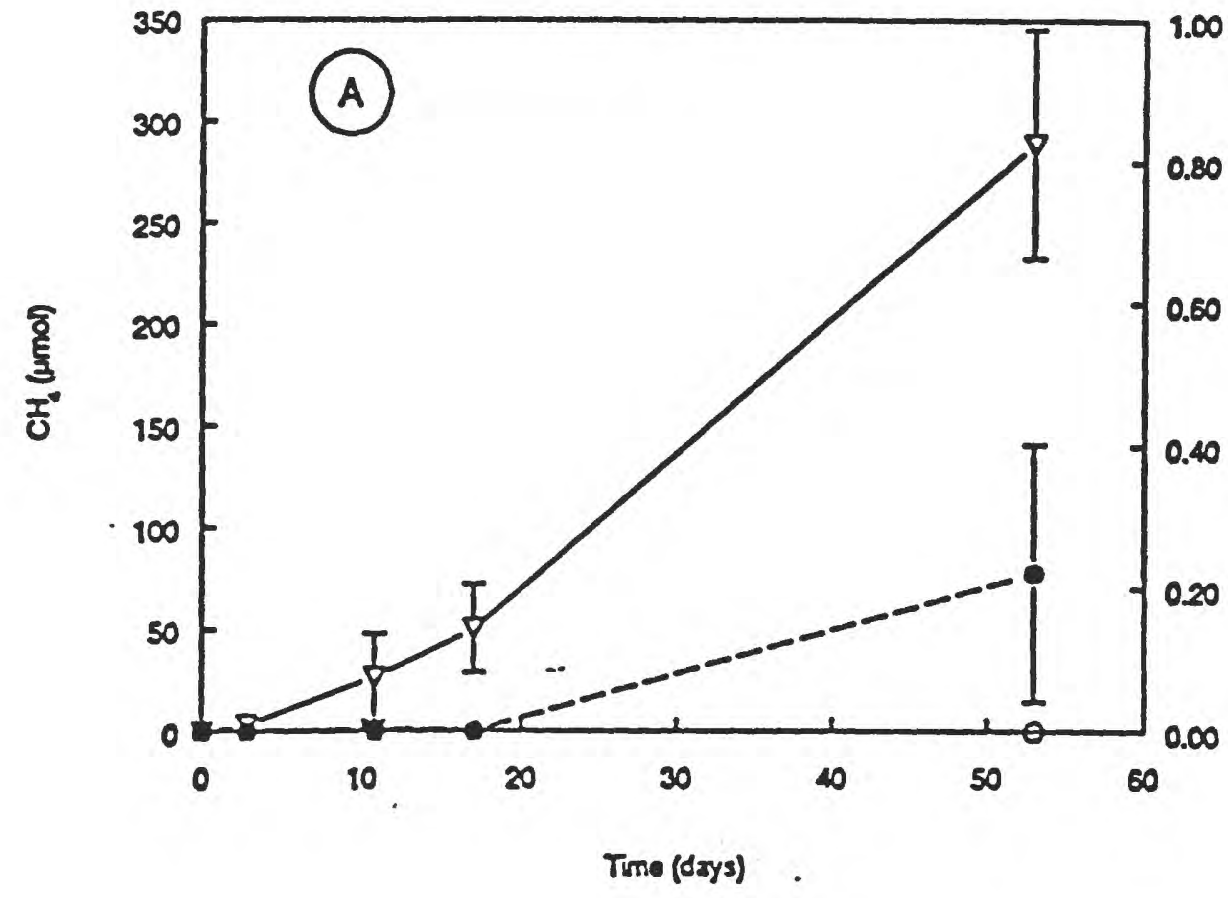

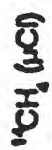

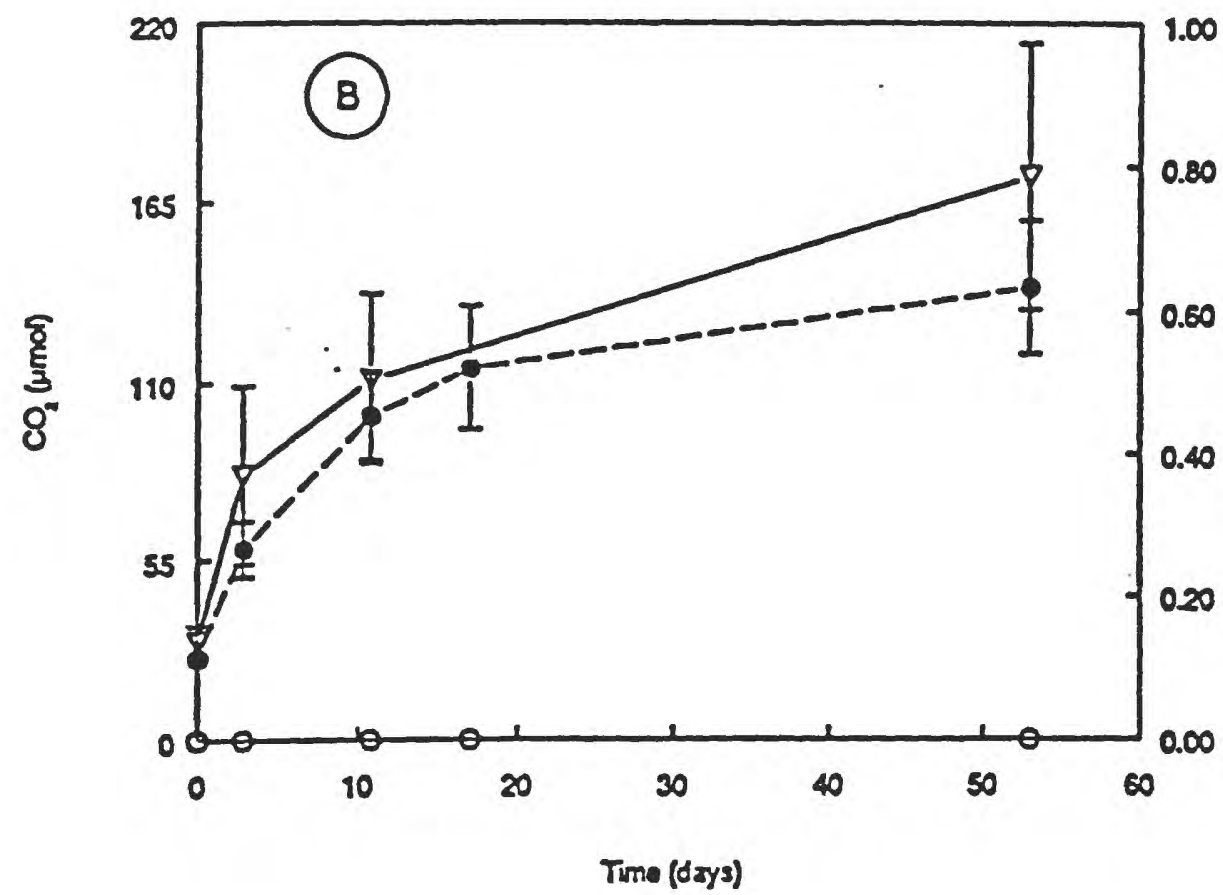

Figure 9. South San Franeiseo Bay saltmarsh sediment collected and slumied anaerobically on 8/3/95. All received $0.91 \mu \mathrm{Ci}$ $(0.8+\mu M) 2.14 \mathrm{C}$.TFA. (A) $\mathrm{CH}_{4}$ and ${ }^{14} \mathrm{CH}_{4}$ : (B) $\mathrm{CO}_{2}$ and ${ }^{14} \mathrm{CO}_{2}$. Symbols: (V) $\mathrm{CH}_{4}$ and $\mathrm{CO}_{2}$ in unamended slurrie; (v) sluries amended with $20 \mathrm{mM}$ sulfate; $(\mathrm{O}){ }^{14} \mathrm{CH}$, and $14 \mathrm{CO}_{2}$ for unamended slurries, which are represeneraive resules for both conditions Symbols represent the mean of three individual slurries and bars indieate $\pm l$ sandard deviation. 

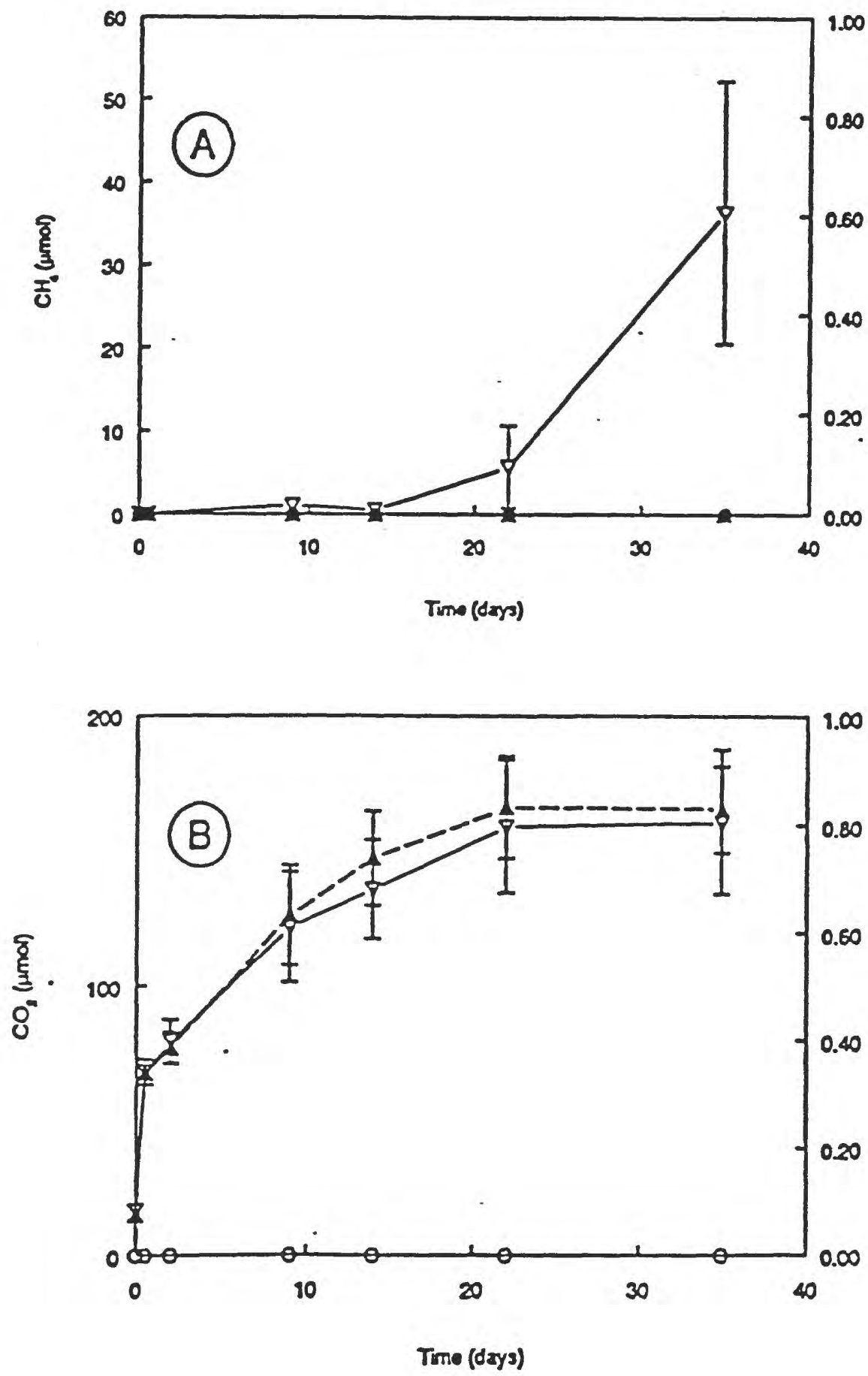

$\frac{8}{3}$

Figure 10. South San Francisco Bay salumarsh sediment collected and slurried anaerobically on $8 / 28 / 95$ with 20 mM sulfate. All received $0.91 \mu \mathrm{Ci}(0.84 \mu \mathrm{M}) 2 .{ }^{4} \mathrm{C}$.TFA $(A) \mathrm{CH}_{4}$ and ${ }^{14} \mathrm{CH}_{4}$; (B) $\mathrm{CO}_{2}$ and ${ }^{14} \mathrm{CO}_{2}$. Symbols: $(\nabla) \mathrm{CH}_{4}$ and $\mathrm{CO}_{2}$ in unamended slurvies (A) sulfate-amended slurries, $(\mathrm{O})^{14} \mathrm{CH}_{4}$ and ${ }^{14} \mathrm{CO}_{2}$ for unameaded sluries, which are representative results for both conditions. Symbols represent the mean of three individual slurric and bass indicale \pm 1 sandard deviation. 

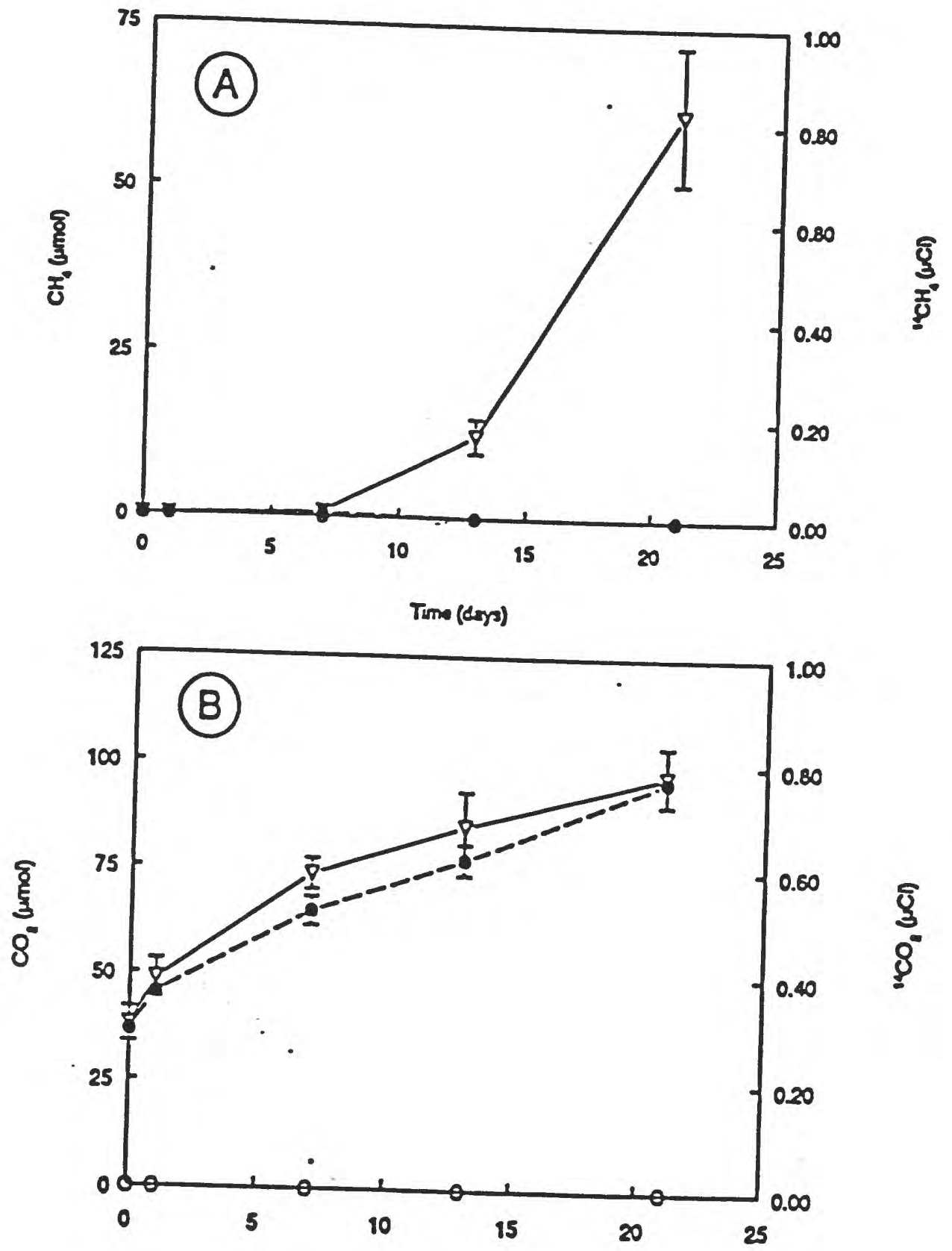

Time (days)

Figure 11. South San Francisco Bay saltmarsh sediment collected and slurried anaetobically on $10 / 3 / 95$ with $20 \mathrm{mM}$ sulfate All received $0.91 \mu \mathrm{Ci}(0.84 \mu \mathrm{M}) 2.14 \mathrm{C}$.TFA (A) $\mathrm{CH}_{4}$ and $14 \mathrm{CH}_{4}$; (B) $\mathrm{CO}_{2}$ and ${ }^{14} \mathrm{CO}_{2}$. Symbols: (V) $\mathrm{CH}_{4}$ and $\mathrm{CO}_{2}$ in unamended sluries, $(\theta)$ sulfate-amended slurries, $(O)^{14} \mathrm{CH}_{4}$ and $14 \mathrm{CO}_{2}$ for unamended slurrica, which are representative results for both conditions. Symbols represent the mean of three individual slurries and bass indicate \pm 1 seandard deviation 
$\cos 100$

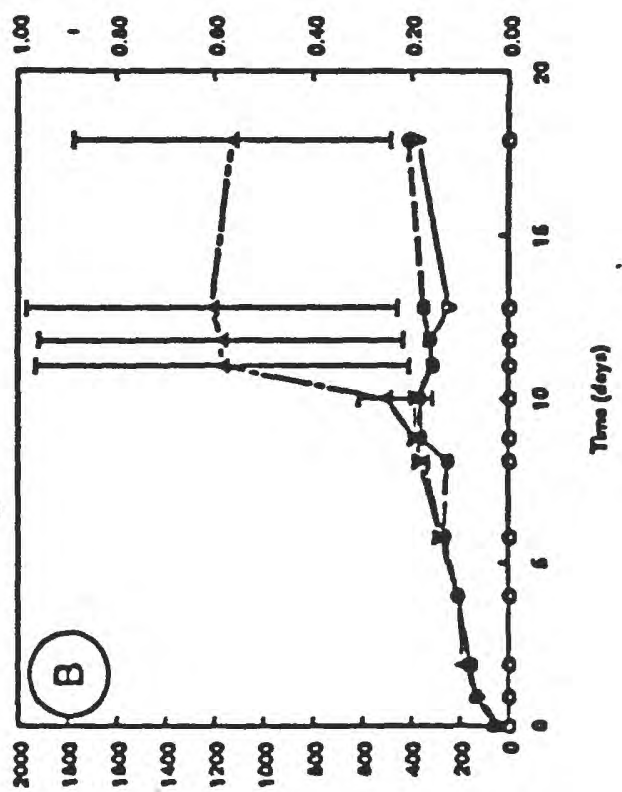

$\tan ^{\circ} \infty$ $\cos ^{2} \infty$

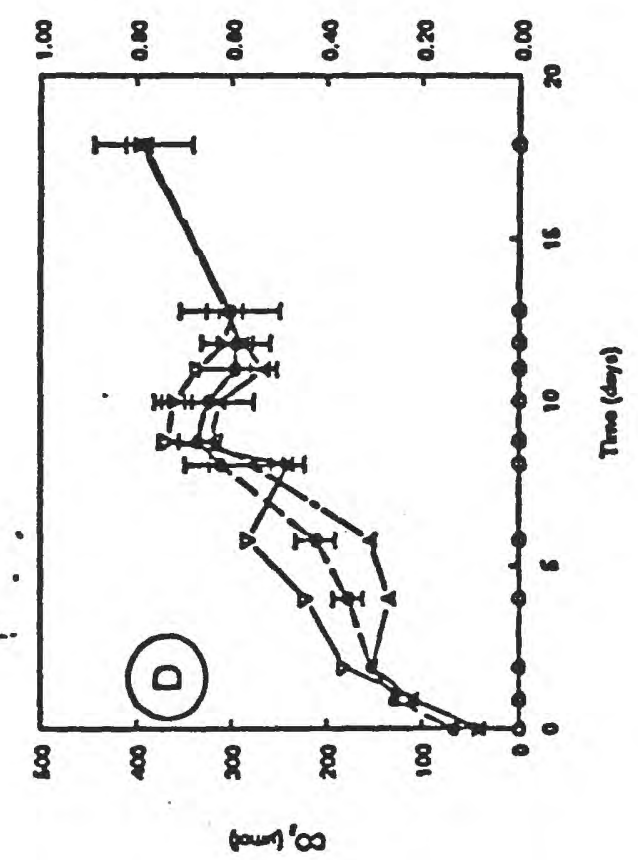

onita.

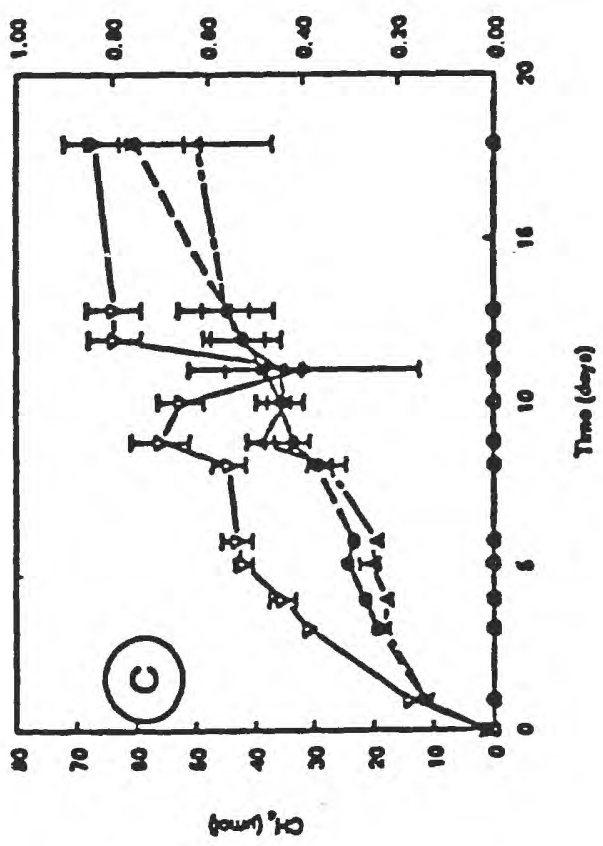

总泀亭

亏월 플 อ를

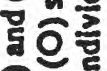

पु

舫

올

두

E E

을

돌

30

은 흔

웅

늘

눙

욜 을

200

등

ระ

진

등흐

으른

द्व

2응

를

을

든

를

온

울

पु

운

눙

E世는

퉁․

폴

들

룰웅

है

$\rightarrow$ E

을 -

올

훈

은

5 है

क $\equiv$ 능

호을

क 5 름

둫하

농

른를 

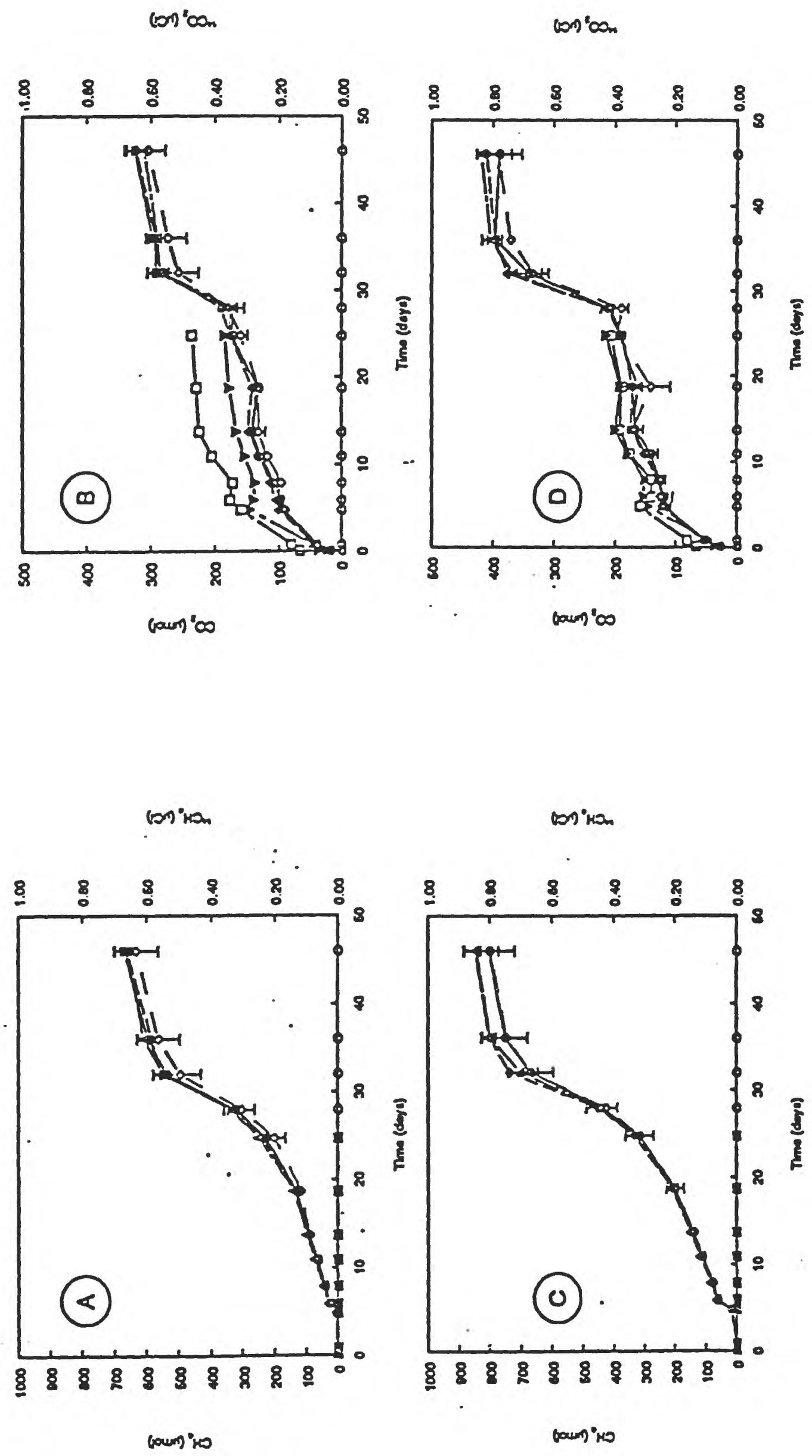

nina 


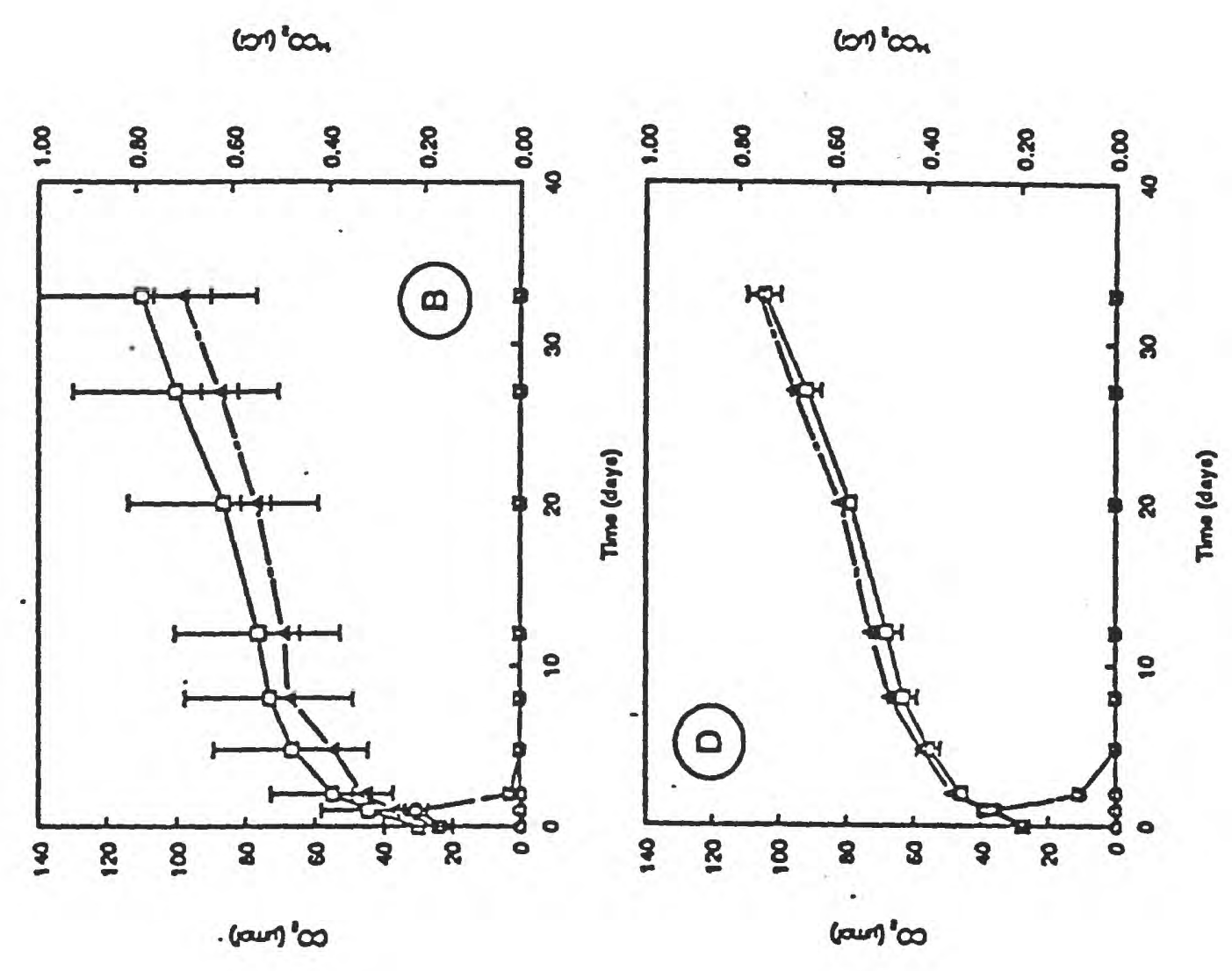

$\cos i x$

(oring.

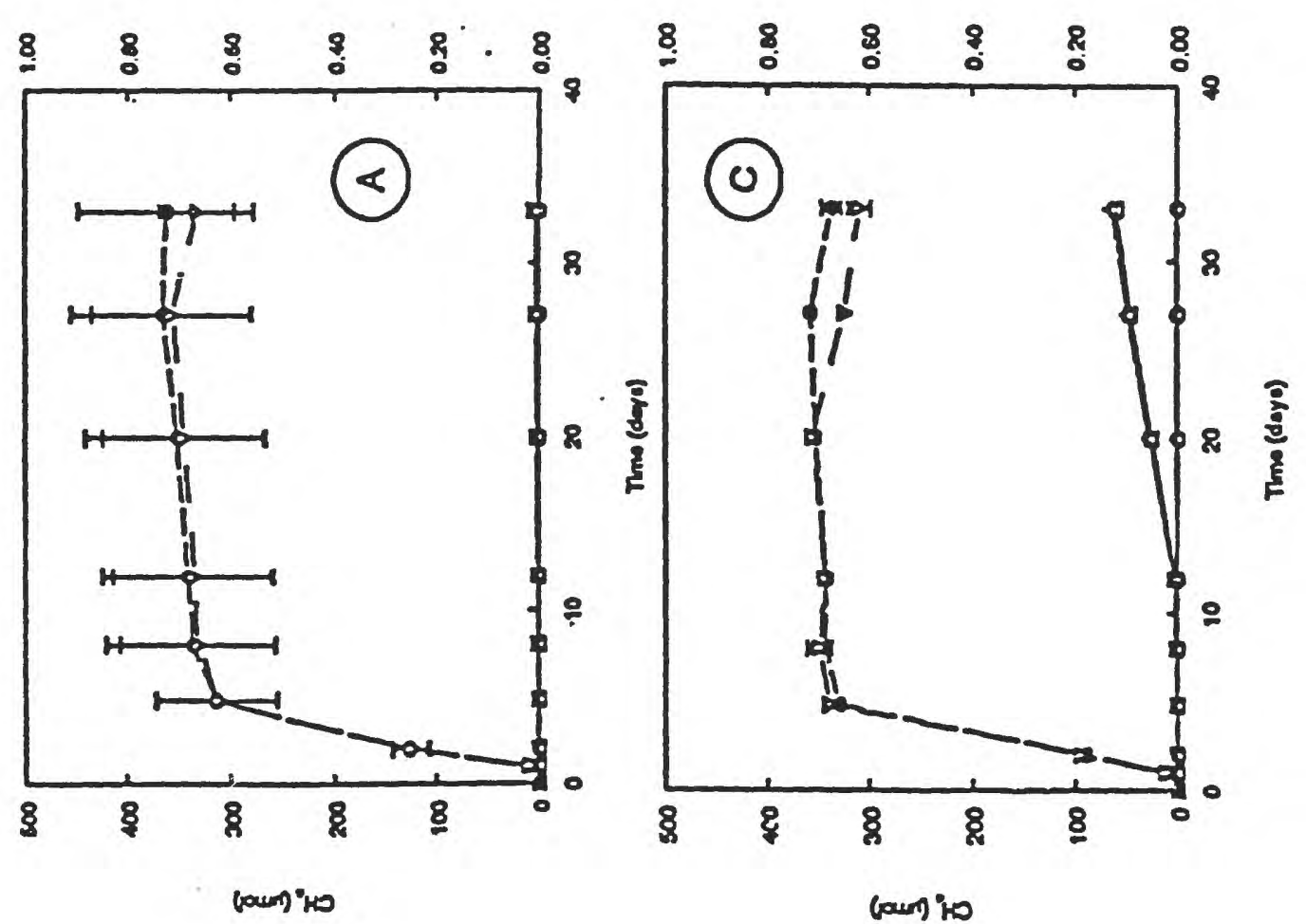

엄

츤

골

总是

함

으ㄹㅗㅗ

홉

Oㄹ

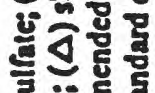

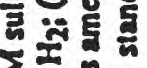

है है

운를

등호흘

웡

둥

의

은

บํㅣㄹ

ํํㅇํㅇㄹㅗ

흘은

ㅇํㅇ

댇요

ह

可旨

है

ㅎํํ 든

돈

롤은

ติํํㅇ

\& 2

ช้․ำ

엉

은 을

政

톡응

훌

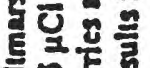

등롤

흐을

\&

ह

द

क है 

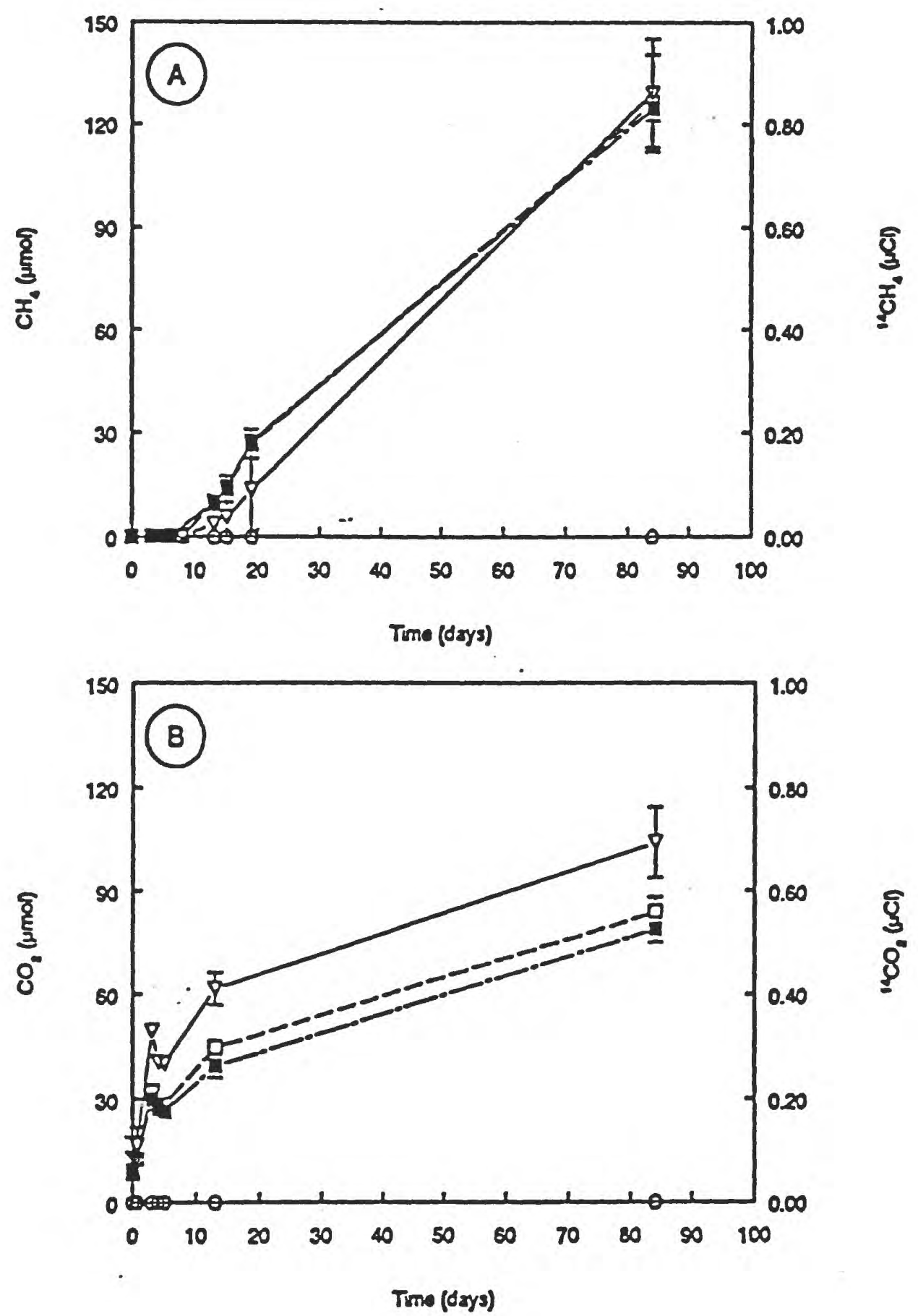

Figure 15. South San Franciseo Bay saltmarsh sediment collected and slurried anaerobically oa $6 / 2295$. The sluries received vaying 2.14 C.TFA concentrations. (A) $\mathrm{CH}_{4}$ and ${ }^{14} \mathrm{CH}_{4}$; $(\mathrm{B}) \mathrm{CO}_{2}$ and ${ }^{14} \mathrm{CO}_{2}$. Symbols: (V) $\mathrm{CH}_{4}$ and $\mathrm{CO}_{2}$ in unamended slurries; (a) slurries amended with $0.5 \mu \mathrm{Ci}(0.46 \mu \mathrm{M}) 2.14 \mathrm{C}$-TFA; (an) $1 \mu \mathrm{Ci}(0.93 \mu \mathrm{M}) 2-14 \mathrm{C}$. TFA; $(0)^{14} \mathrm{CH}_{4}$ and $14 \mathrm{CO}_{2}$ for sluries amended with i $\mu \mathrm{Ci}(0.93 \mu \mathrm{M}) 2.14 \mathrm{C}$-TFA, which are representacive results for all conditions Symbols represent the mean of three individual slurries and bars indicate \pm 1 standard deviation. 

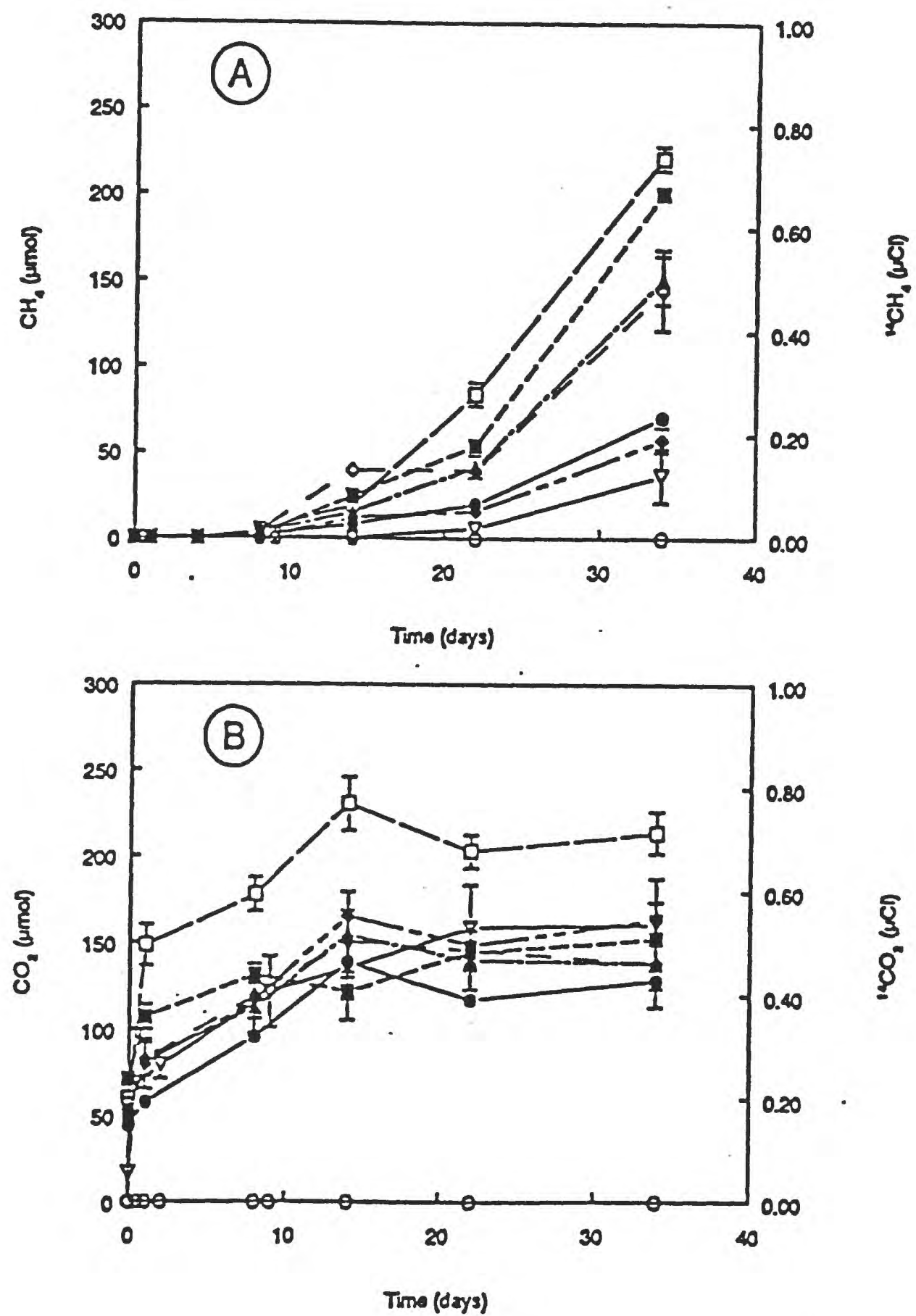

Figure 16. South San Franciseo Bay saltmarsh sediment collected on \&28/95 and sluried anaerobically with 5 mM of various electron donors on 8/29/95. All reeeived $0.91 \mu \mathrm{Ci}(0.84 \mu \mathrm{M})$ 2.14 C.TFA (A) $\mathrm{CH}_{4}$ and ${ }^{14} \mathrm{CH}_{4}$; (B) $\mathrm{CO}_{2}$ and $14 \mathrm{CO}_{2}$. Symbols: $(\nabla) \mathrm{CH}_{4}$ and $\mathrm{CO}_{2}$ in unamended slurries; $(\theta)$ oxalate-amended slurries, (ii) propionate; (A) lactate; (O) pyruvate; (D) glueose; $(\$)$ benzoare; $(O){ }^{14} \mathrm{CH}_{4}$ and $14 \mathrm{CO}_{2}$ for unamended sluries, which are representative resules for all cosdirions Symbols represent the mean of three individual slurries and bars indicate $\pm l$ seandard deviacion. - 


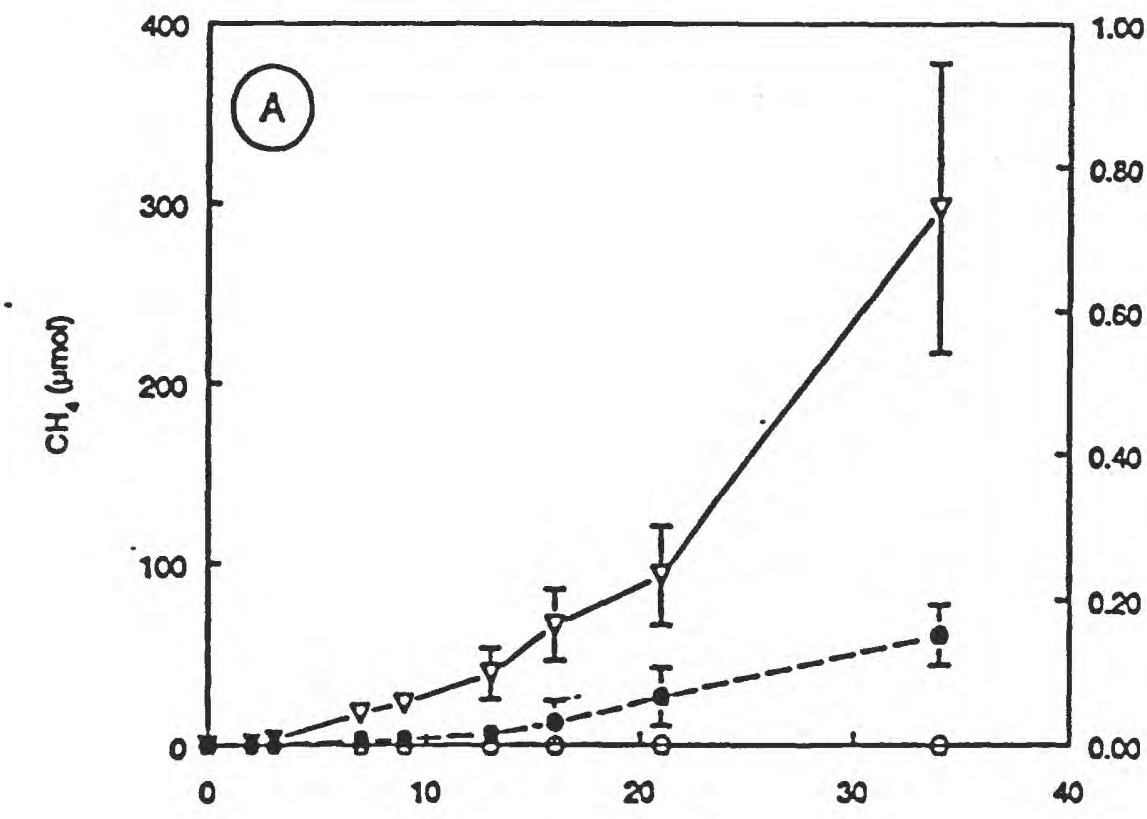

$\frac{0}{3}$

Time (days)

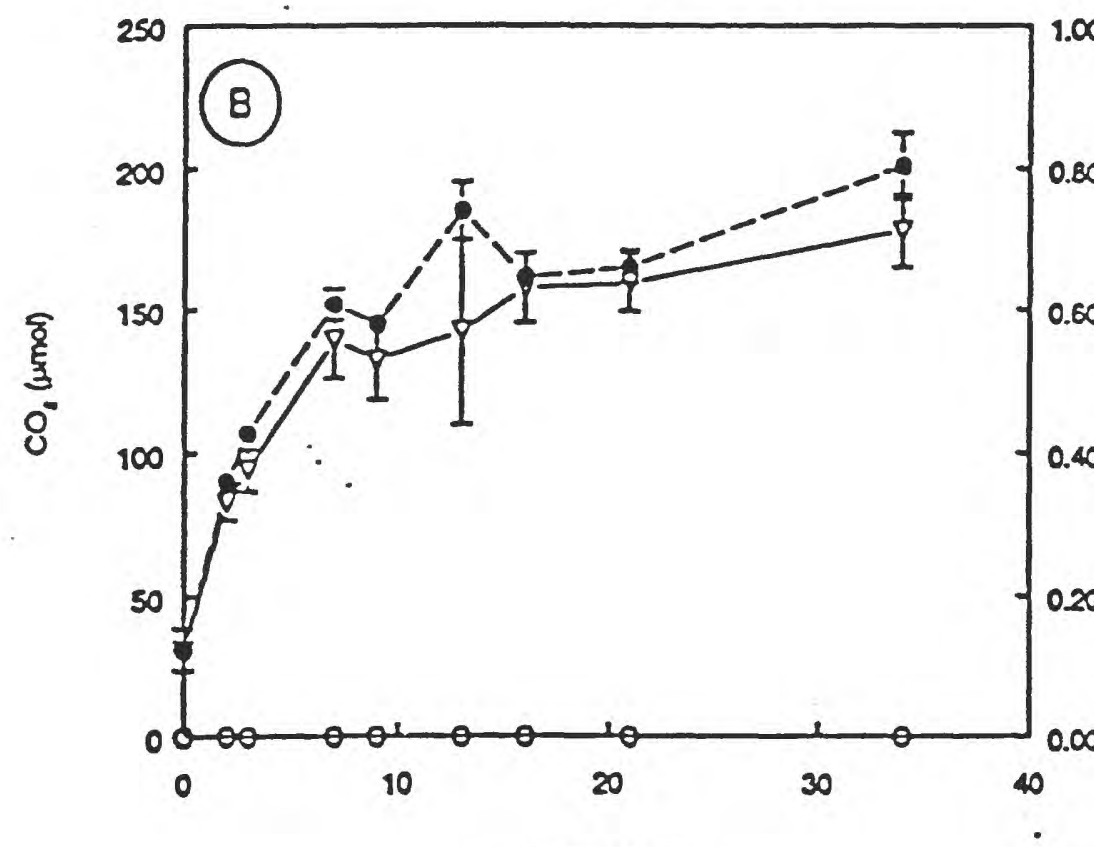

Time (days)

Figure 17. Sourh San Francisco Bay salunarsh sediment collected $6 / 93$ and sluried anaerobically, with or without $20 \mathrm{mM}$ sulfate on $5 / 23 / 95$. All slurries received $0.8 \mu \mathrm{Ci}(0.74 \mu \mathrm{M}) 2 \cdot{ }^{14} \mathrm{C}$-TFA $(A) \mathrm{CH}_{4}$ and ${ }^{14} \mathrm{CH}_{4}$. (B) $\mathrm{CO}_{2}$ and ${ }^{14} \mathrm{CO}_{2}$. Symbols: $(\nabla) \mathrm{CH}_{4}$ and $\mathrm{CO}_{2}$ in unamended slurries, $(0)$ sulfate-amended slurrier, $(O)^{14} \mathrm{CH}_{4}$ and ${ }^{14} \mathrm{CO}_{2}$ for unamended slurries, which are representative resulus for all conditions. Symbols represent the mean of three individual slurries and bass indicate \pm 1 randard deviation 

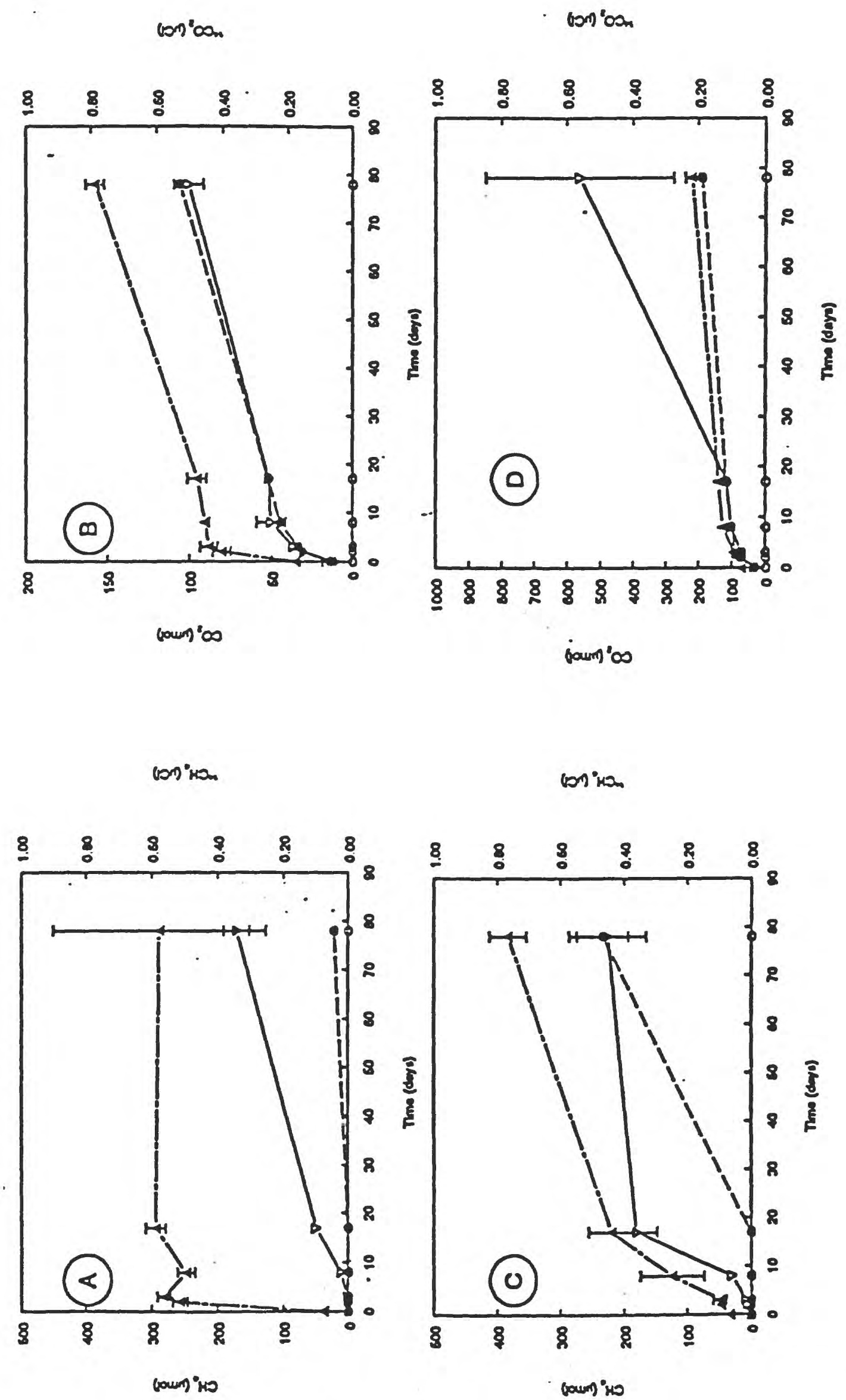

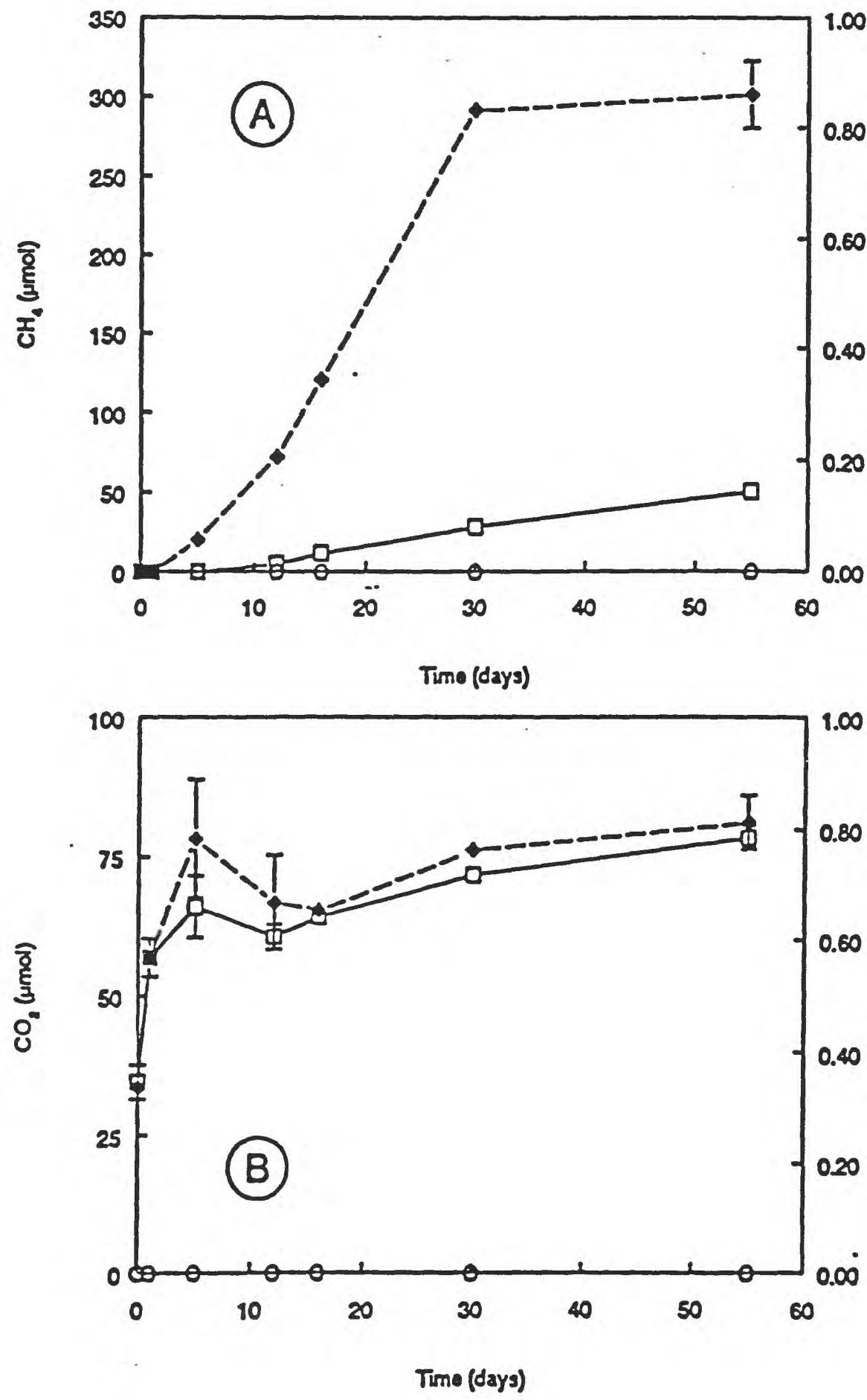

Figure 19. South San Francisco Bay saltmarsh sediment collected and slurried anaerobically on \&/9/95 with 0.1 mMMH4 $\mathrm{Cl}$ and $20 \mathrm{mM}$ acetate. All received $0.91 \mu \mathrm{Ci}(0.84 \mu \mathrm{M}) 2-14 \mathrm{C}$ - TFA (A) CH4 and ${ }^{14} \mathrm{CH}_{4}$; (B) CO and ${ }^{14} \mathrm{CO}_{2}$. Symbols: (D) CH4 and $\mathrm{CO}_{2}$ in slurries amended with $\mathrm{NH}_{4} \mathrm{Cl}_{7}(\diamond)$ slurries amended with $\mathrm{NH}_{4} \mathrm{Cl}_{\text {and }}$ acetate; $(O){ }^{14} \mathrm{CH}_{4}$ and $14 \mathrm{CO}_{2}$ for $\mathrm{NH}_{4} \mathrm{Cl}$ amended slurries, which are representative results for both conditions. Symbols represent the mean of three individual siurries and bass indicate \pm 1 sandard deviation. 

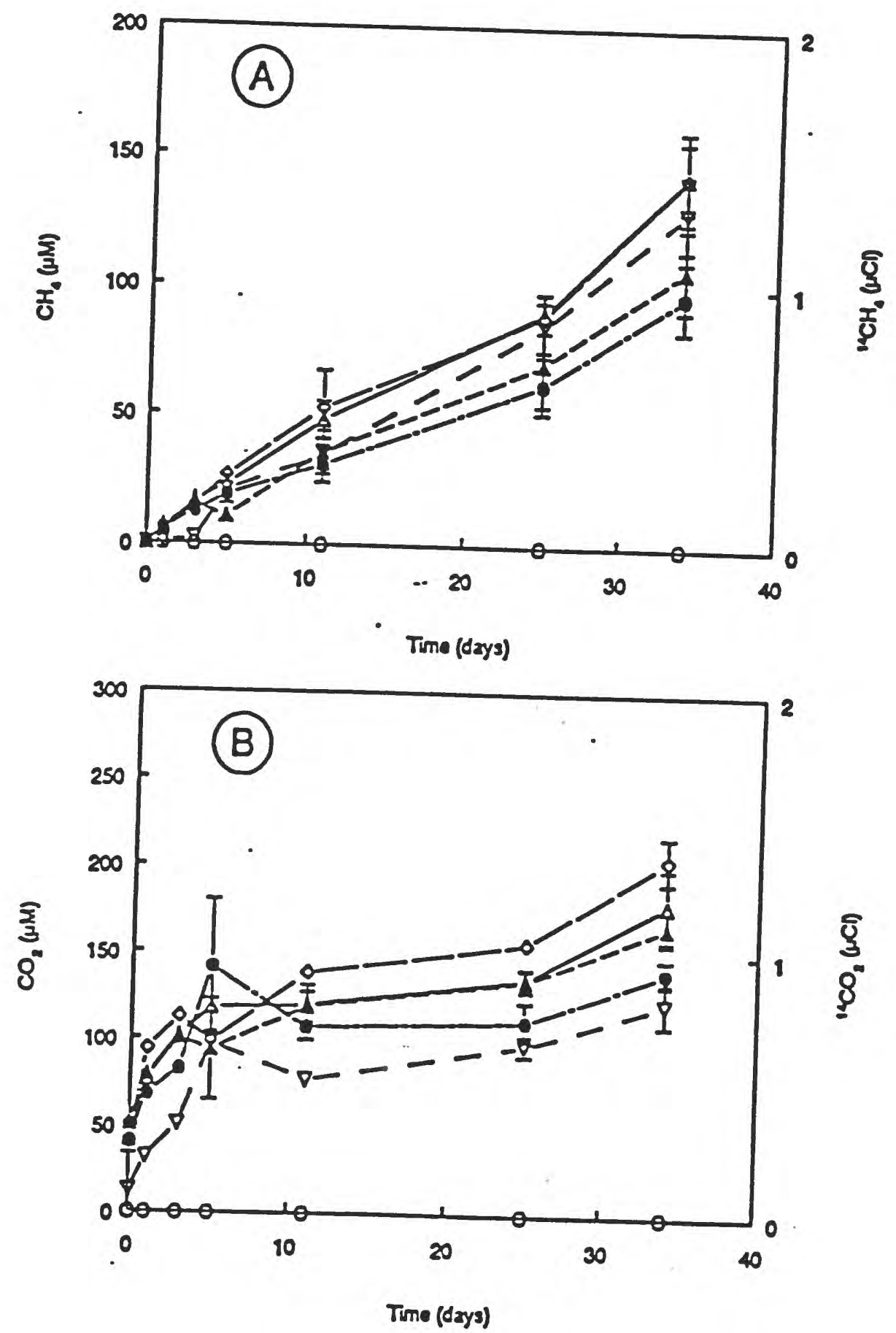

Figure 20. South San Francisco Bay saltmarsh sediment slurries pre-incubated with 1 HM TFA, DFA, MFA, acetate, or no addition. Sediments collected on 6/295, sluried anaerobically on 6/15/95, and incubated with additions until each was subsampled on 7/2895 and amended with $0.91 \mu \mathrm{Ci}\left(0.84\right.$ i2M) 2.14 C.TFA. (A) $\mathrm{CH}_{4}$ and $14 \mathrm{CH}_{4}$ : (B) $\mathrm{CO}_{2}$ and $14 \mathrm{CO}_{2}$. Symbols: (A) $\mathrm{CH}_{4}$ and $\mathrm{CO}_{2}$ in slurries pre-incubaled with TFA; (A) DFA; $(0) \mathrm{MF} \mathrm{A}_{i}(\nabla)$ acetate; $(0)$ no addition; $(O){ }^{14} \mathrm{CH}_{4}$ and three individual slurries and bass indiease \pm 1 standard deviation 

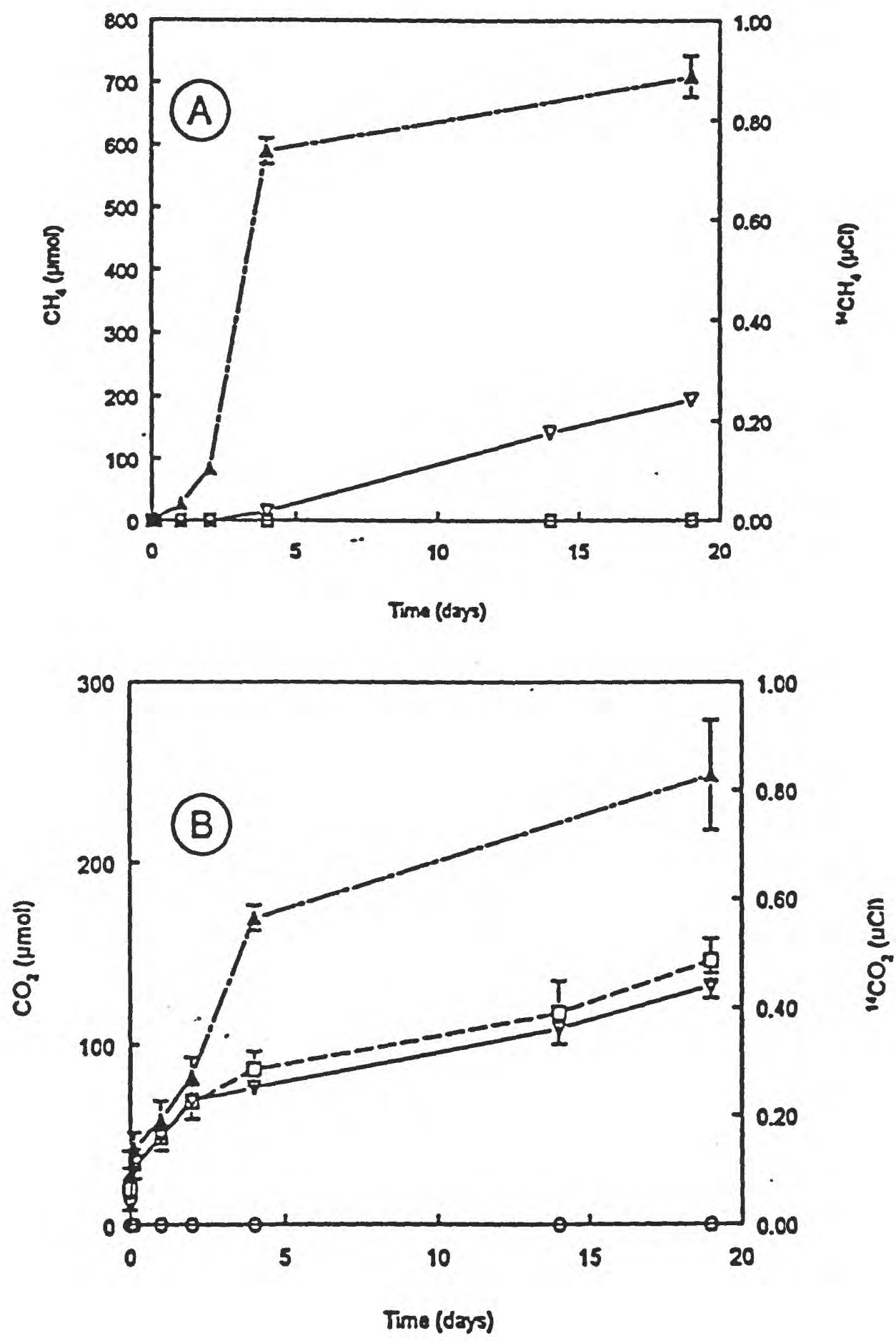

Figure 21. Botinas Bay salemarsh sediment from the south sampling location. Collected on $5 / 3 / 95$ and slurried anaerobially on

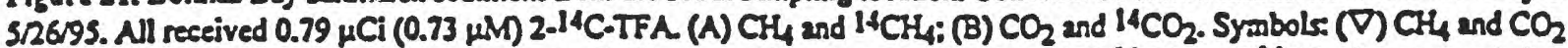
in unamended slurries; (D) slurries amended wieh $20 \mathrm{mM}$ sulfate; $(\Delta) 10 \mathrm{mi}^{3} \mathrm{MMA}(O){ }^{14} \mathrm{CH}_{4}$ and ${ }^{14} \mathrm{CO}_{2}$ for unamended slurries, which are representative results for all conditions. Symbols represent the mean of three individual slumies and bars indiease \pm 1 seandard deviacion. 

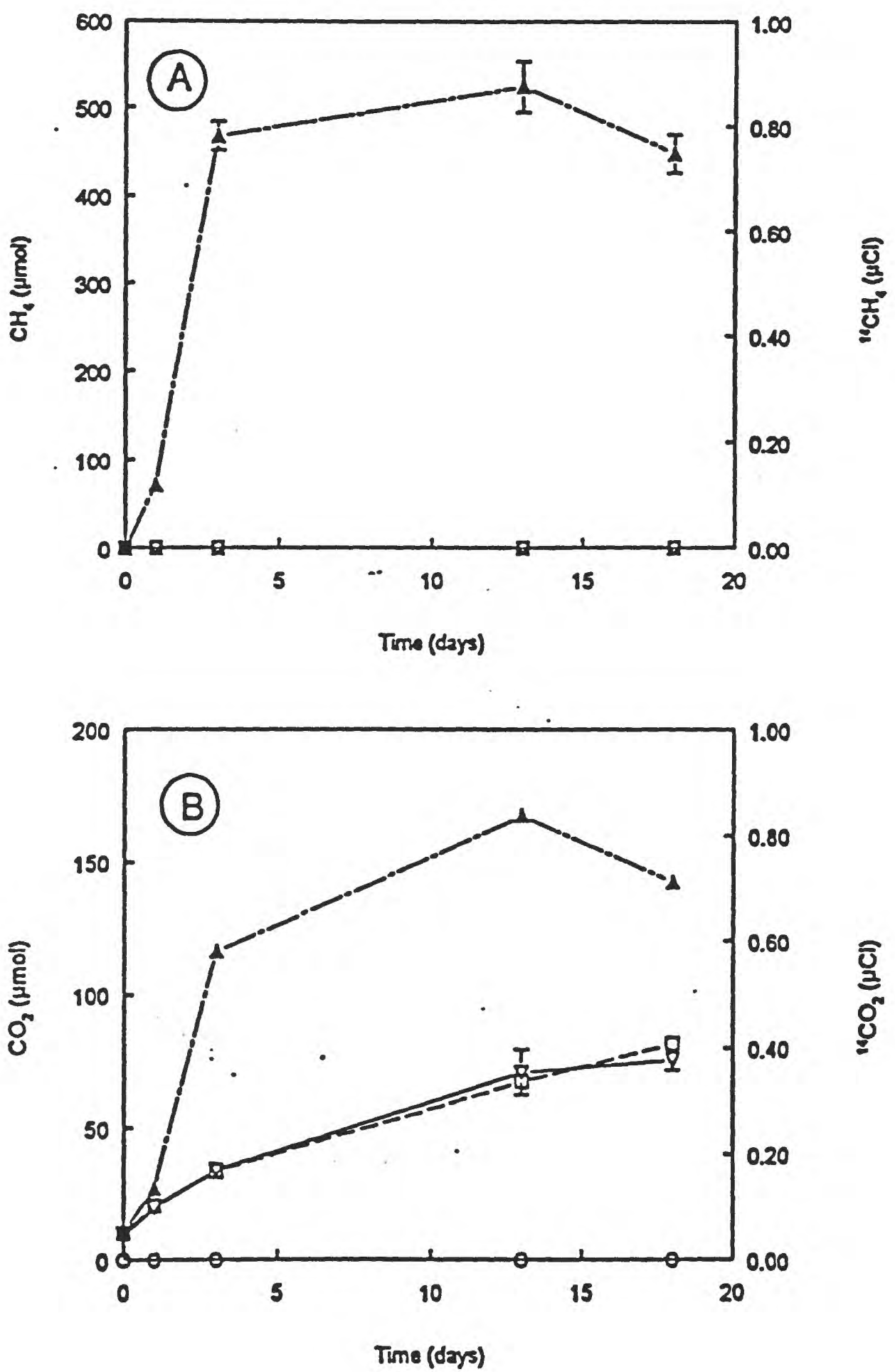

Figure 22. Bolinas Bay saltmarsh sediment from tine north sampling location. Collected on S/3/95 and slurried anaerobically on

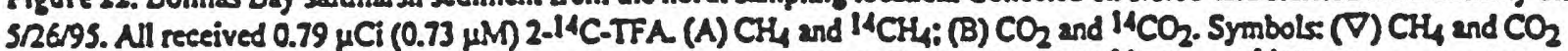
in unamended slurries (D) slurries anended with $20 \mathrm{mM}$ sulfare; $(A) 10 \mathrm{mM} \mathrm{TMU}_{i}(O)^{14} \mathrm{CH}_{4}$ and ${ }^{14} \mathrm{CO}_{2}$ for unamended slurries, which are representative results for all conditions Symbols represent the mean of three individual sluries and bars indicate \pm I standard deviation. 

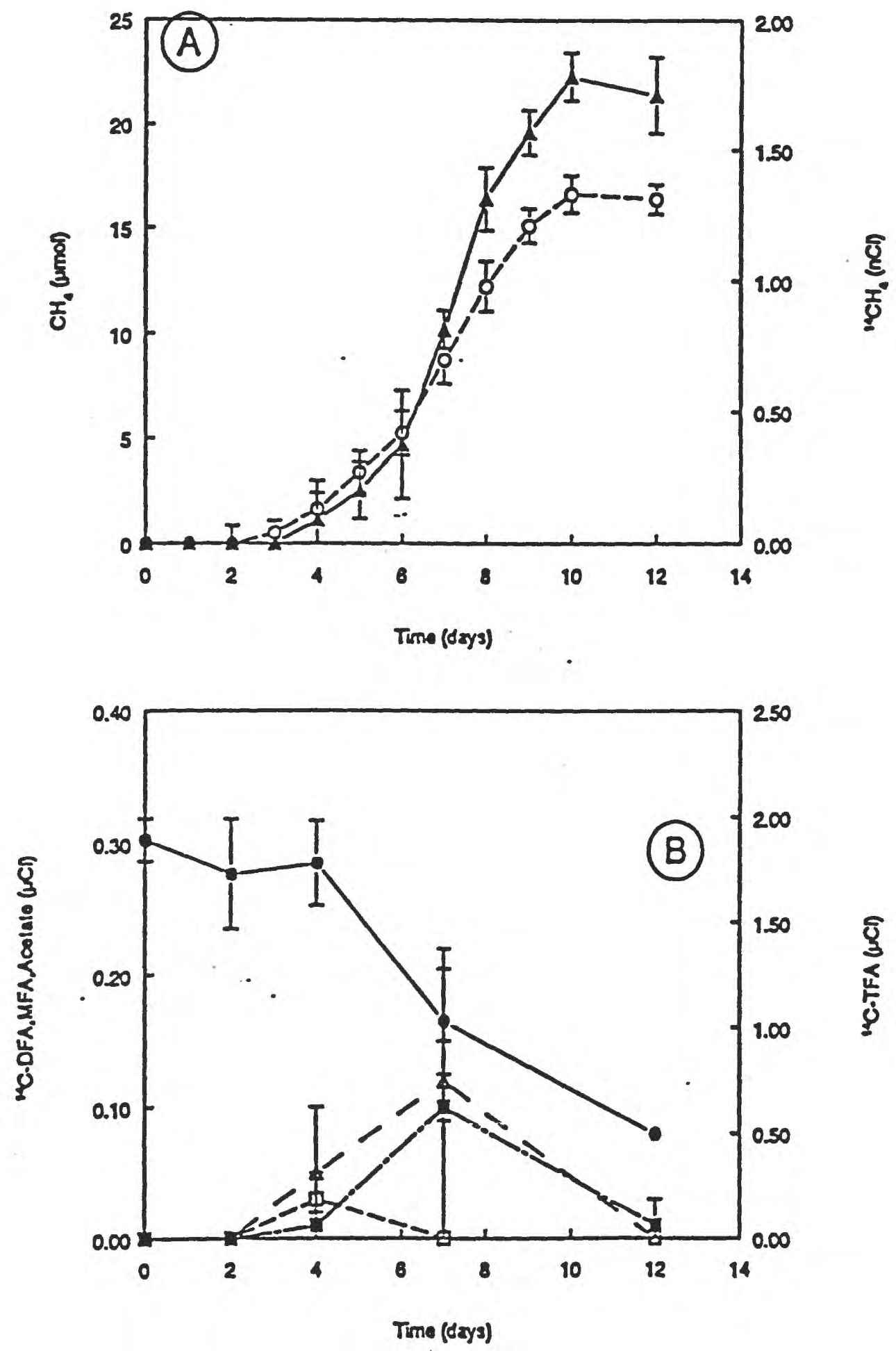

Figure 23. Degradation of $1.85 \mu \mathrm{Ci}(1.71 \mu \mathrm{M}) 2.14 \mathrm{C}$. TFA in Searsville lake freshwater sediment collected and siurried anacrobically on 10/6/93. (A) $\mathrm{CH}_{4}$ and $14 \mathrm{CH} 4$. (B) disappearance of 2-14 C.TFA and appearnee of $14 \mathrm{C}$-liquid phase products.

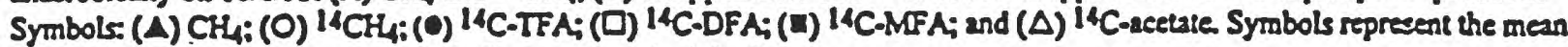
of three individual sluries and bars indieate \pm 1 standard deviacion. 


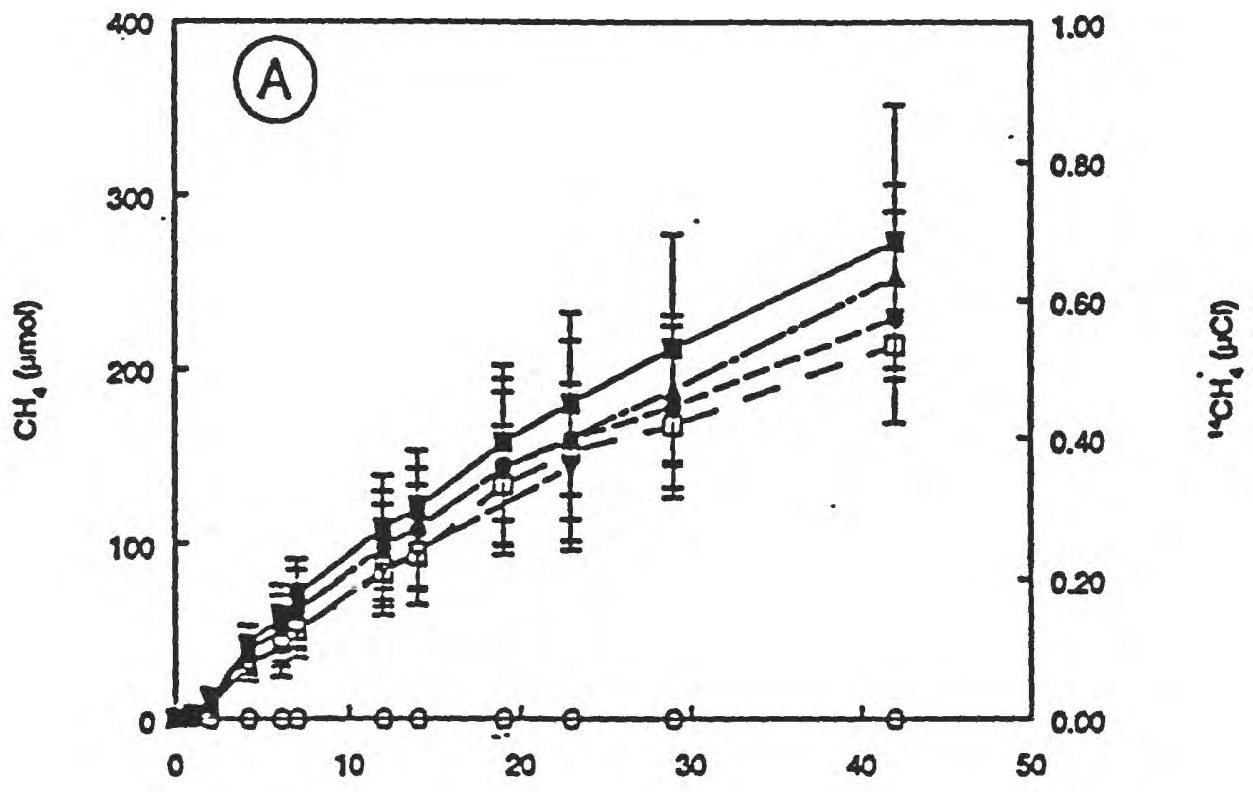

Time (days)

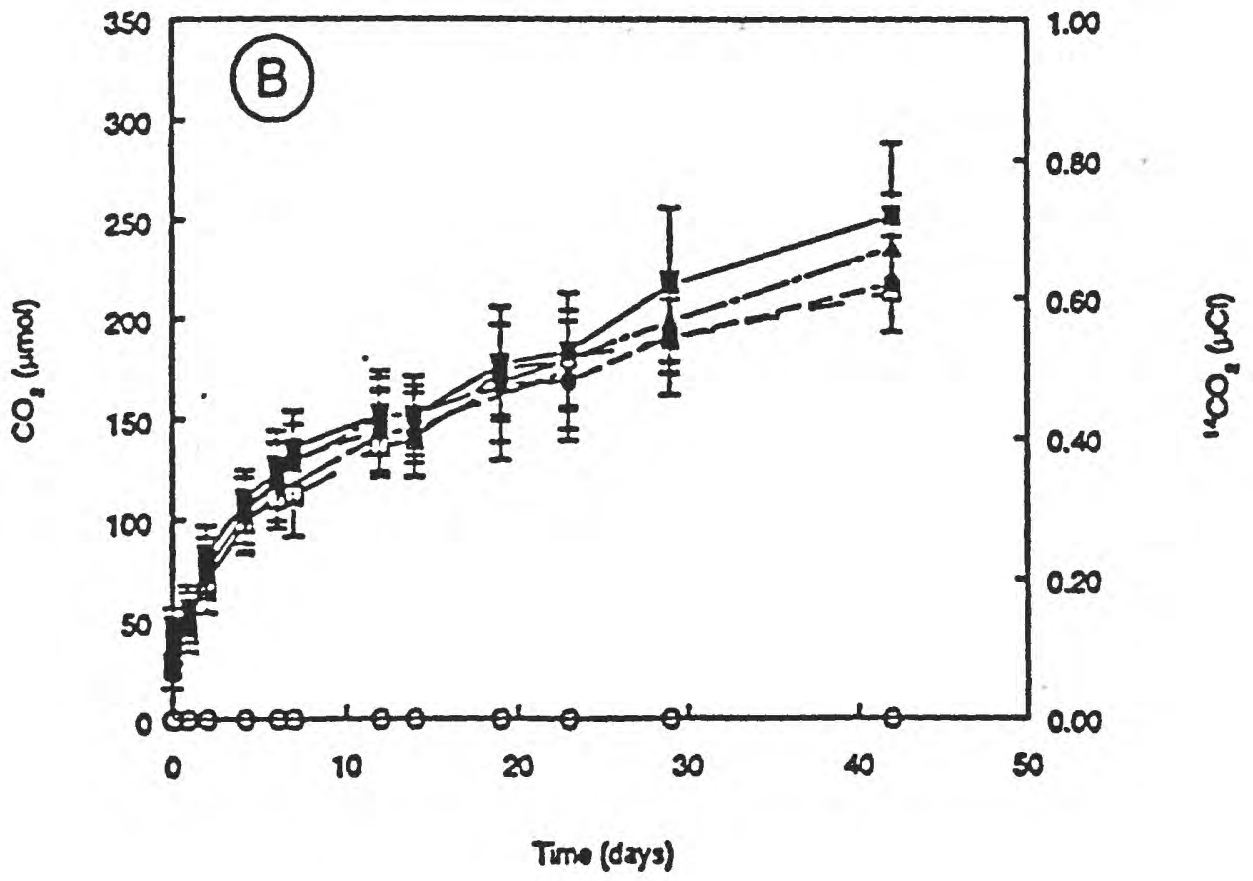

Figure 24. Searsville Lake freshwater sediments collected and slurried anaerobically on V/1895 and amended wieh varying coneentrations of 1.14C.TFA and 2.14C.TFA. (A) $\mathrm{CH}_{4}$ and ${ }^{14} \mathrm{CH} 4$; (B) $\mathrm{CO}_{2}$ and ${ }^{14} \mathrm{CO}_{2}$. Sjmbols (V) $\mathrm{CH}_{4}$ and $\mathrm{CO}_{2}$ in

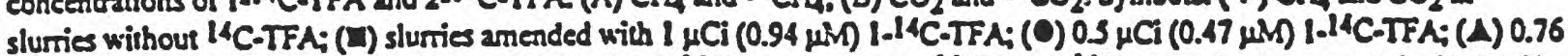
$\mu \mathrm{Ci}(0.70 \mu \mathrm{M}) 2.14 \mathrm{C}$-TFA $(\mathrm{C}) 0.38 \mu \mathrm{Ci}(0.35 \mu \mathrm{M}) 2.14 \mathrm{C}$-TFA $(\mathrm{O})$ show $14 \mathrm{CH}_{4}$ and $14 \mathrm{CO}_{2}$ for slurries amended with $\mathrm{I} \mu \mathrm{Ci}$ $(0.94 \mathrm{MV})$ 1-14 C-TFA, which are sepresentative results for all condivions. Symbols represent the mean of three individual slurries and bars indicase $\pm l$ standard deviation. 


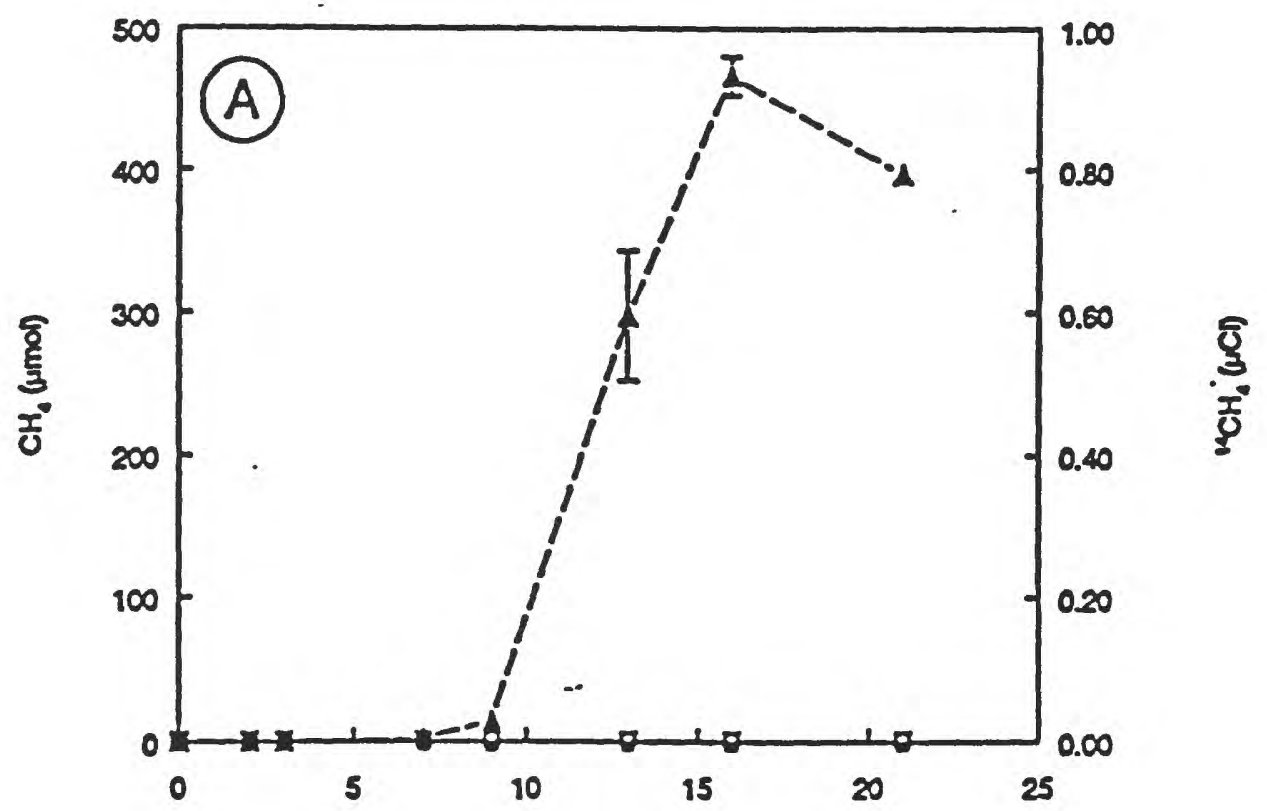

Time (days)

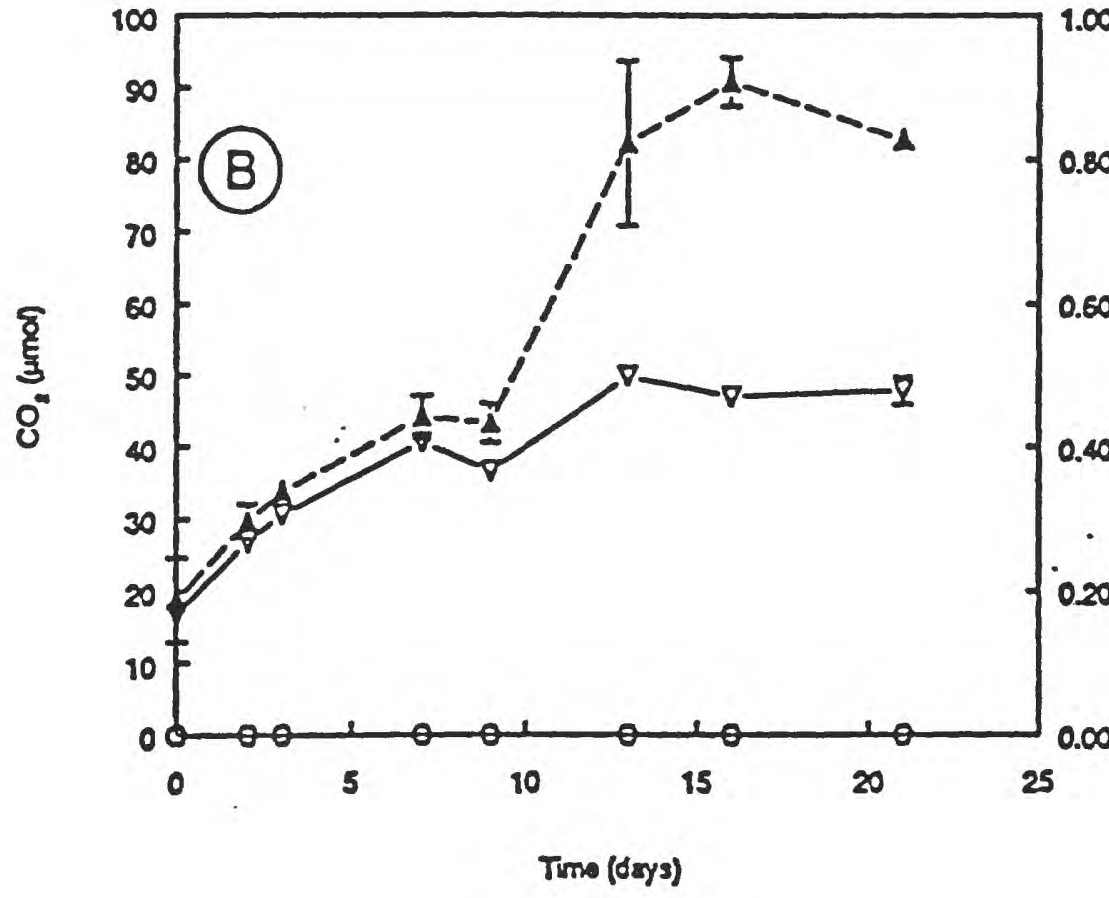

Figure 25. Searsville Lake sediment collected on 10.93 and slurried anaerobieally on $5 / 23 / 95$. All received $0.79 \mu \mathrm{Cl}(0.73 \mu \mathrm{M})$ 2.14 C.TFA. (A) $\mathrm{CH}_{4}$ and ${ }^{14} \mathrm{CH}_{4}$ : (B) $\mathrm{CO}_{2}$ and ${ }^{14} \mathrm{CO}_{2}$. Symbols: (V) $\mathrm{CH}_{4}$ and $\mathrm{CO}_{2}$ in unamended slurries (A) $10 \mathrm{mM} \mathrm{TMA}$; (O) ${ }^{14} \mathrm{CH}_{4}$ and $14 \mathrm{CO}_{2}$ for unamended slurrics, which are representalive resuls for all conditions. Symbols represent the mean of three individual slurries and bars indicate \pm 1 standard deviation 


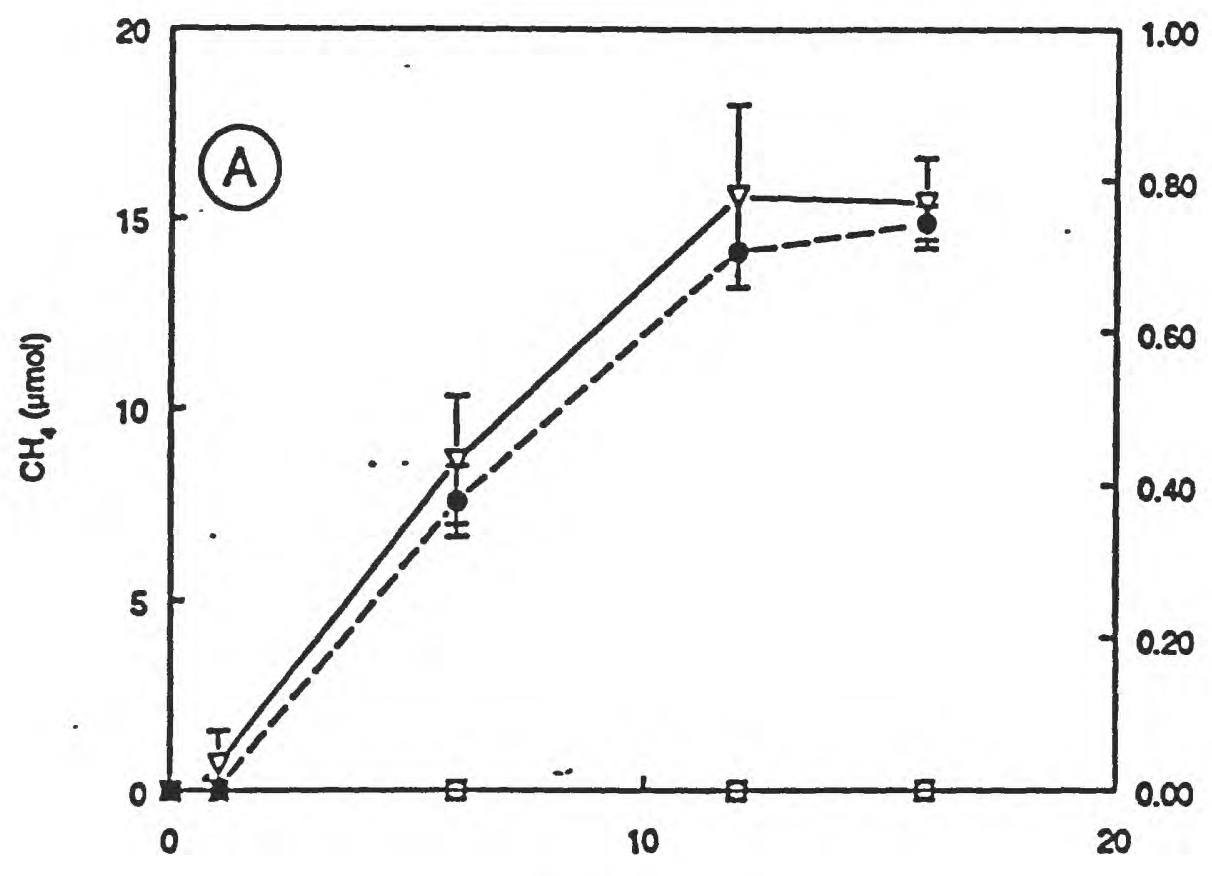

힐

Time (days)

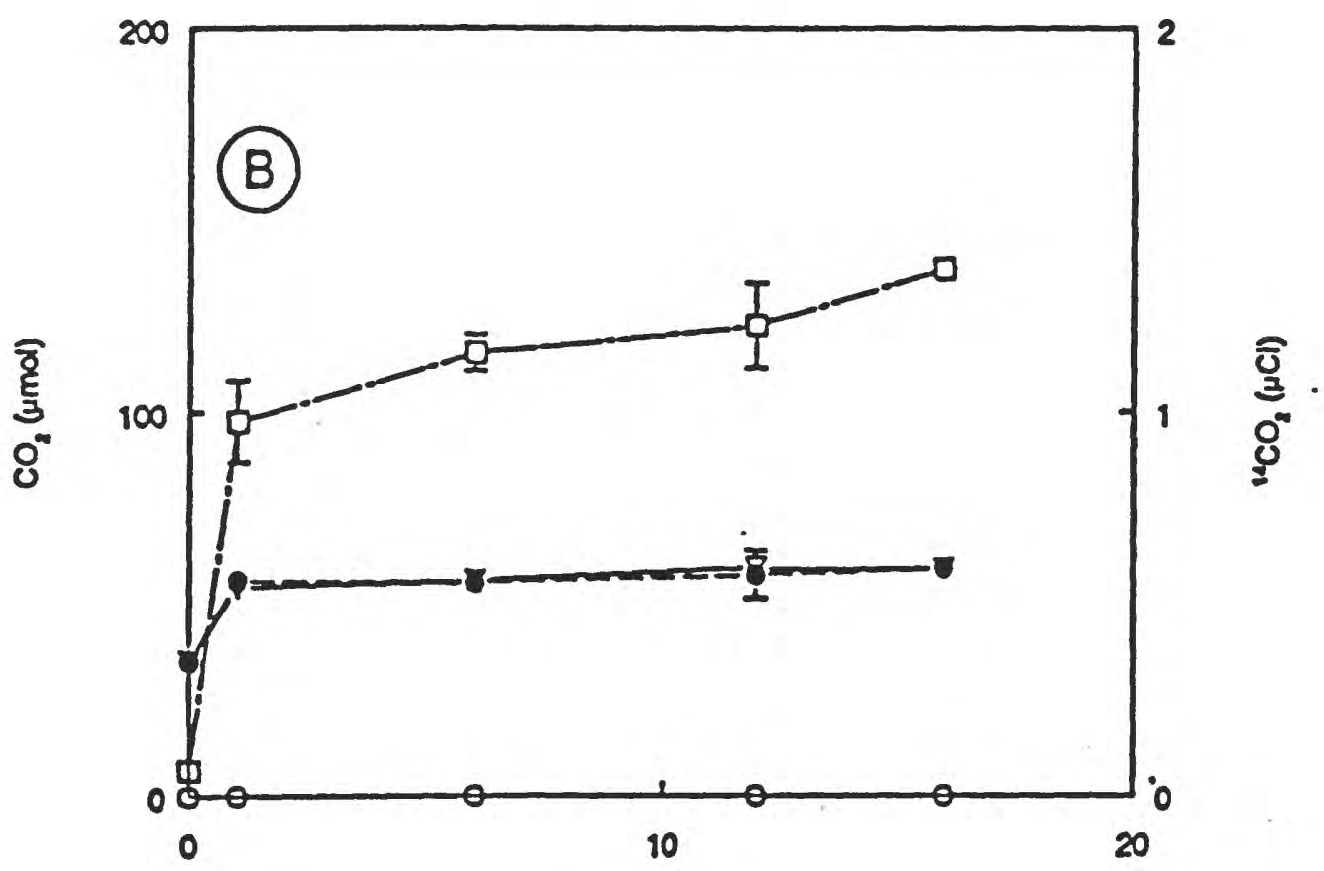

Tine (days)

Figure 26. Searsville Lake sediment collected and slurred anzerobically and aerobically on \&/89S. All received $0.91 \mu \mathrm{Ci}(0.86$

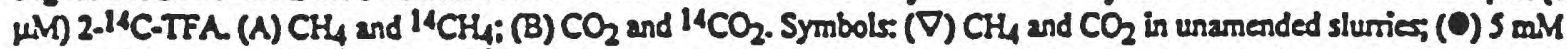
sulfase; (D) acrobic $(\mathrm{O})^{14} \mathrm{CH}_{4}$ and $14 \mathrm{CO}_{2}$ for unamended anaerobie sluries, which are representative results for all conditions. Symbols represent the mean of three individual shirries and bars indicate \pm l sandard deviation 

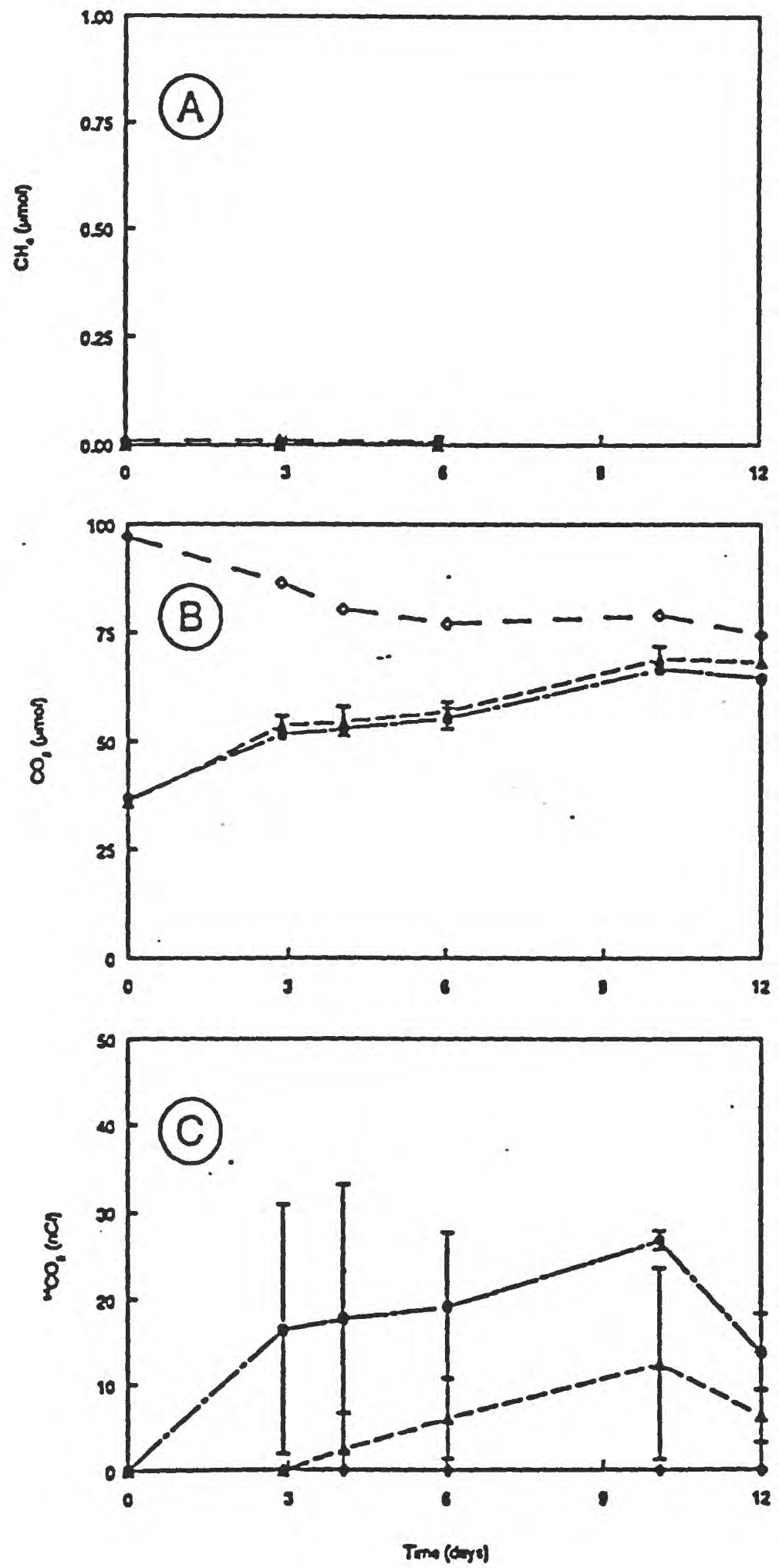

Figure 27. Sacramento Delta peat soil collected on 107/91 and slurried anaerobieally on 4/194 with 20 mis aitrate (A) CH4:

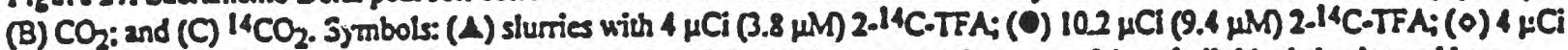
(3.8 $\mu$ h) $2.14 \mathrm{C}$.TFA added after slumies were autoclaved. Symbols represent the mean of three individual slurries and bars indiale \pm 1 seandard deviation. 

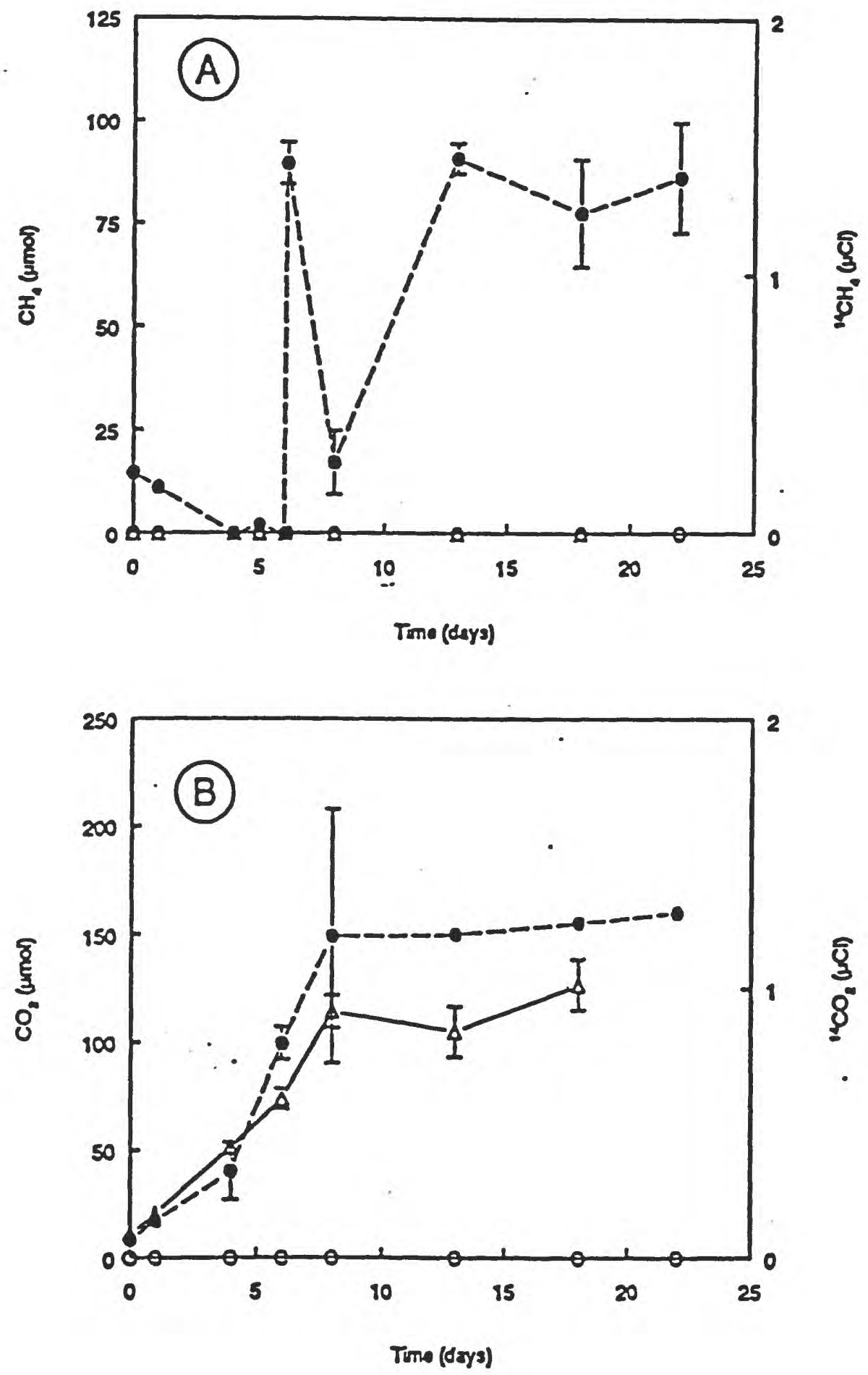

Figure 28. Sactamento Deliz peat soil collected 8/9/95 and sluried aerobically on 8/24/95 with CH4 and $\mathrm{O}_{2}$. All received 0.91 $\mu \mathrm{Ci}(0.86 \mu \mathrm{M}) 2-14 \mathrm{C}$-TFA. Methane and oxygen re-adḍed on day $\mathrm{S}_{3} 8$ and 18 . (A) $\mathrm{CH}_{4}$ and ${ }^{14} \mathrm{CH}_{4} ;(B) \mathrm{CO}_{2}$ and ${ }^{14} \mathrm{CO}_{2}$. Symbols: $(\Delta)$ slurries without methane or oxygen; $(\theta)$ slurries with methane and oxygen; $(O){ }^{14} \mathrm{CH}_{4}$ and $14 \mathrm{CO}_{2}$ for slurries with methane and oxyger, which are representative results for all conditions. Symbols represent the mean of three individual slurries and bars indicase \pm 1 standard deviation. 


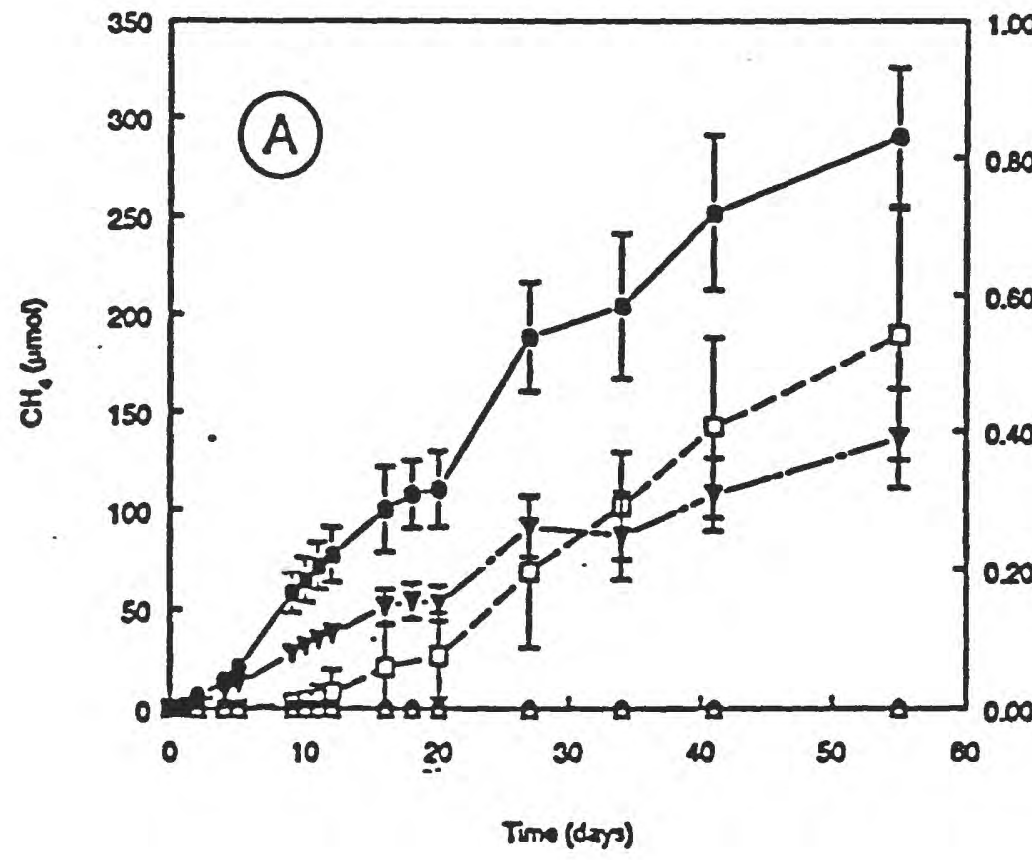

$\frac{9}{9}$

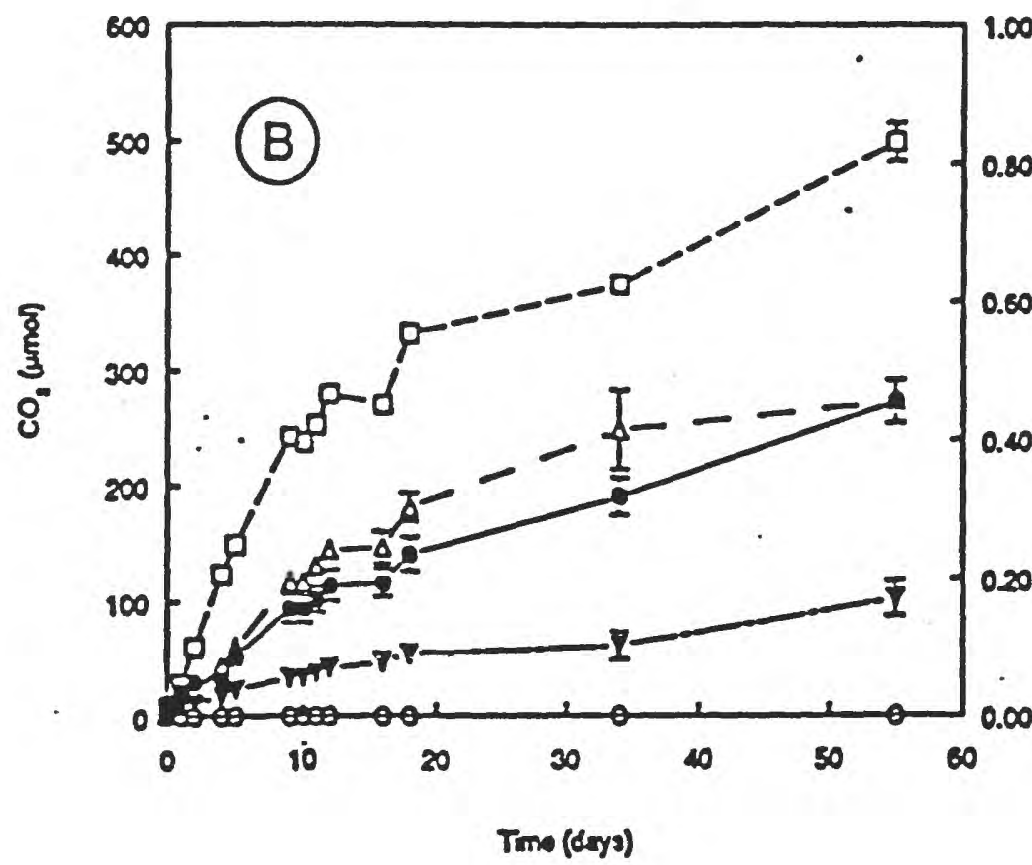

$\frac{\bar{\zeta}}{8}$

Figure 29. Fores soil collected 6/14/95 and sluried anaerobically or 2erobieally on 6/16/95. All received i $\mu \mathrm{Ci}(0.93 \mu \mathrm{M}) 2$. ${ }_{14} \mathrm{C}$. TFA. (A) $\mathrm{CH}_{4}$ and ${ }^{14} \mathrm{CH}_{4}$; (B) $\mathrm{CO}_{2}$ and ${ }^{4}{ }^{4} \mathrm{CO}_{2}$. Symbols: $\mathrm{CH}_{4}$ and $\mathrm{CO}_{2}$ in $(\theta)$ anaerobic surface soil slurrie; (D) aerobic surface soil slurries $(M)$ anaerobic subsurface soil slurries; $(\Delta)$ aerobie subsurface soil slurries $(O)^{14} \mathrm{CH}_{4}$ and ${ }^{14} \mathrm{CO}_{2}$ for anacrobic surface soil slurries, which are representative results for all conditions. Symbols represent the meen of three individual slurries and bars indicare \pm 1 standard deviation. 

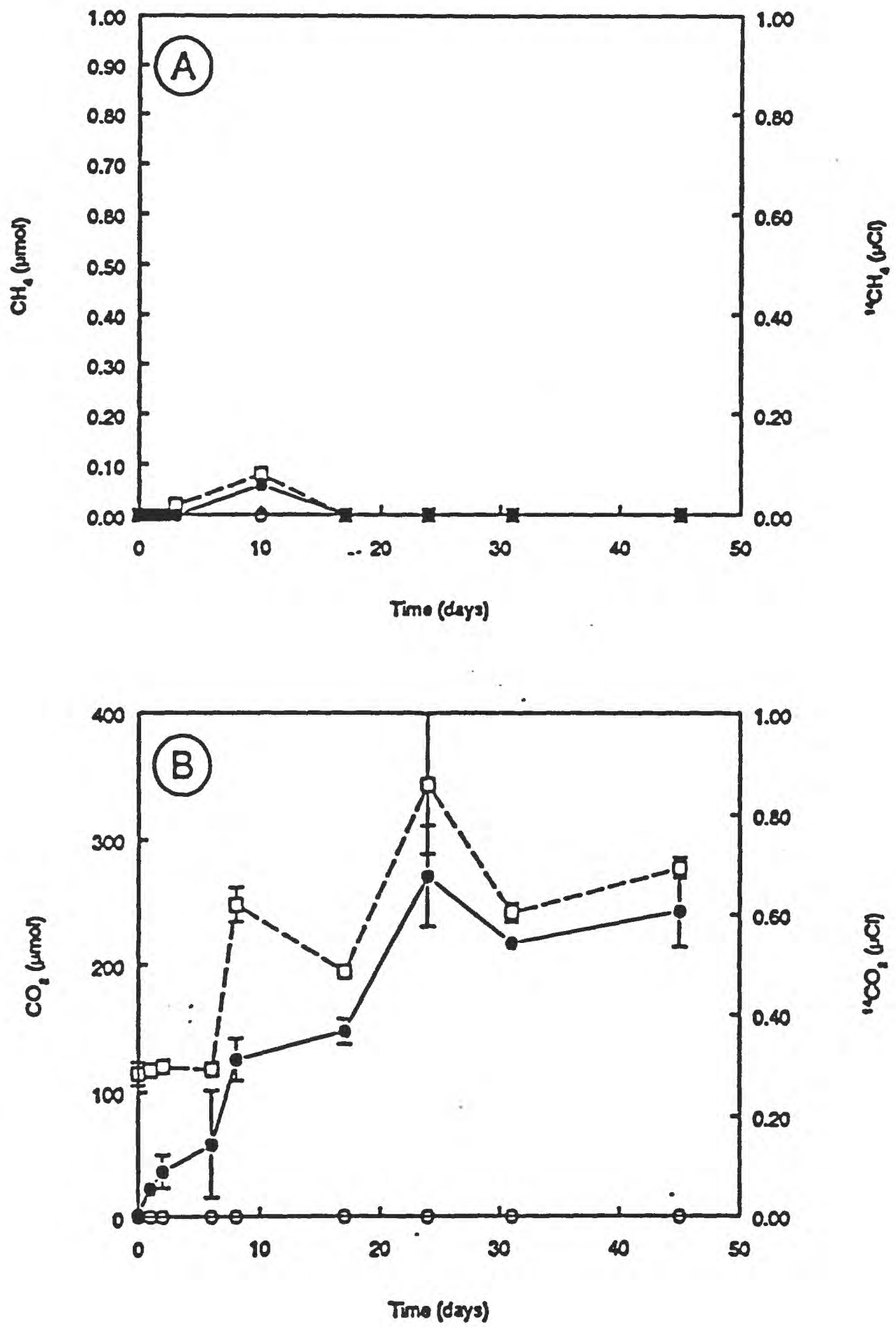

Figure 30. Forest soil collected 6/14/95 and slurried aerobially on 6/26/95. All received $1 \mu \mathrm{Ci}(0.93 \mu \mathrm{M}) 2-14 \mathrm{C}$.TFA (A) CH4 and 14CH4: (B) $\mathrm{CO}_{2}$ and $14 \mathrm{CO}_{2}$. Oxygen addition made at beginning of experiment and periodically throughout Symbols: (O) $\mathrm{CH}_{4}$ and $\mathrm{CO}_{2}$ in live aerobic surface soil slurries, (D) auroclaved aerobic surface soil slurries; $(O)^{14} \mathrm{CH}_{4}$ and $14 \mathrm{CO}_{2}$ for live slurries, which are representacive results for all conditions. Symbols represent the mean of three individual slurries and bars indiease $\pm l$ standard deviation. 


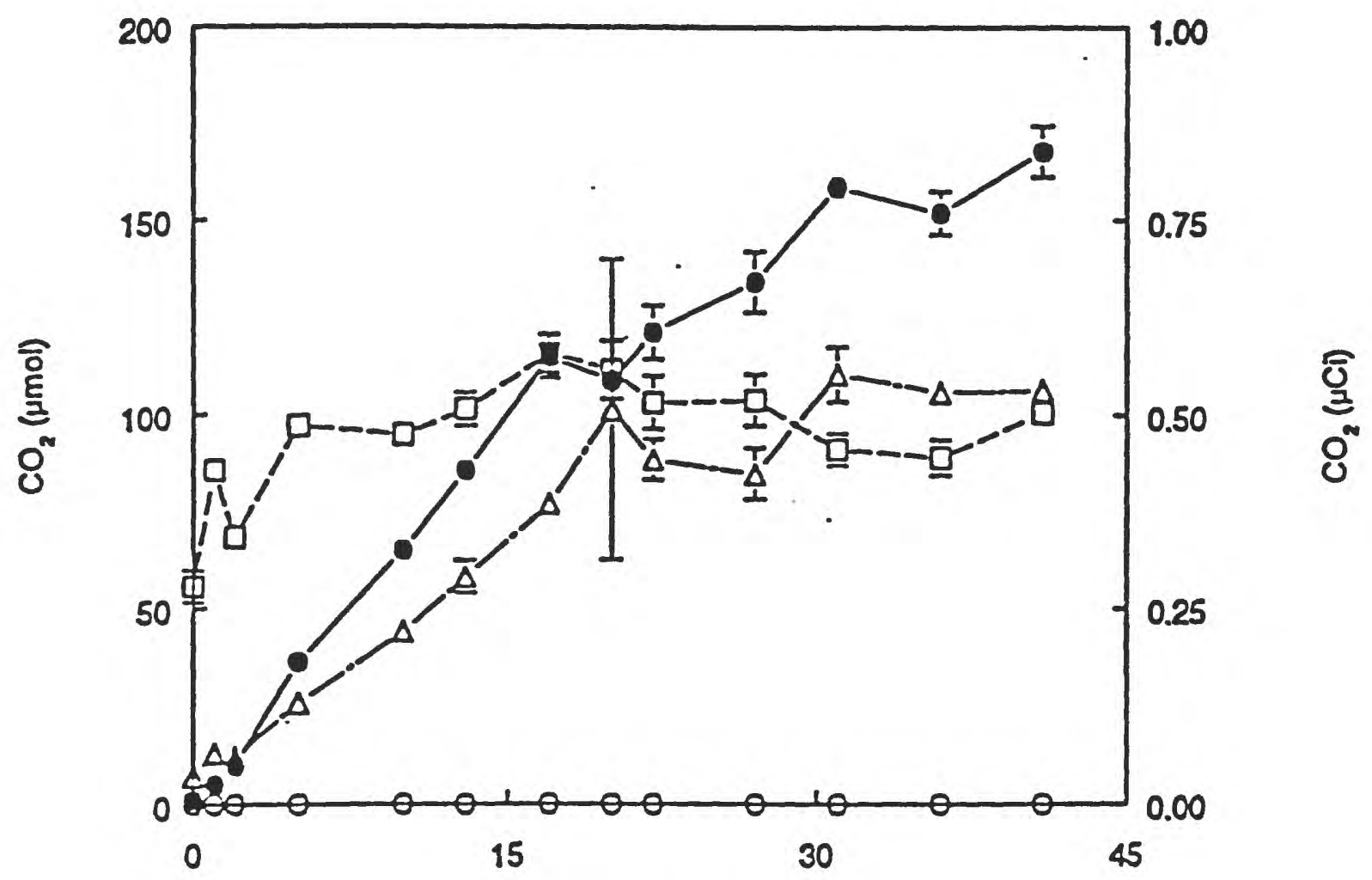

Time (days)

Figure 31. Forest soil from site 1, collected 7/7/95. Slurried acrobially and anacrobically on 7/1 1/95. All received $0.91 \mu \mathrm{Ci}$ $(0.86 \mu \mathrm{M}) 2.14 \mathrm{C}$-TFA. Symbols $\mathrm{CO}_{2}$ for $(Q)$ anaerobic soil slurries $(\Delta)$ aerobic sluries $(\square)$ atroclaved aerobic soil slurries; $(O)$ and $14 \mathrm{CO}_{2}$ for anasrobic slurries, which are representative results for all conditions. Symbols represent the mean of three individual slurries and tars indiease $\pm l$ standard deviation. 


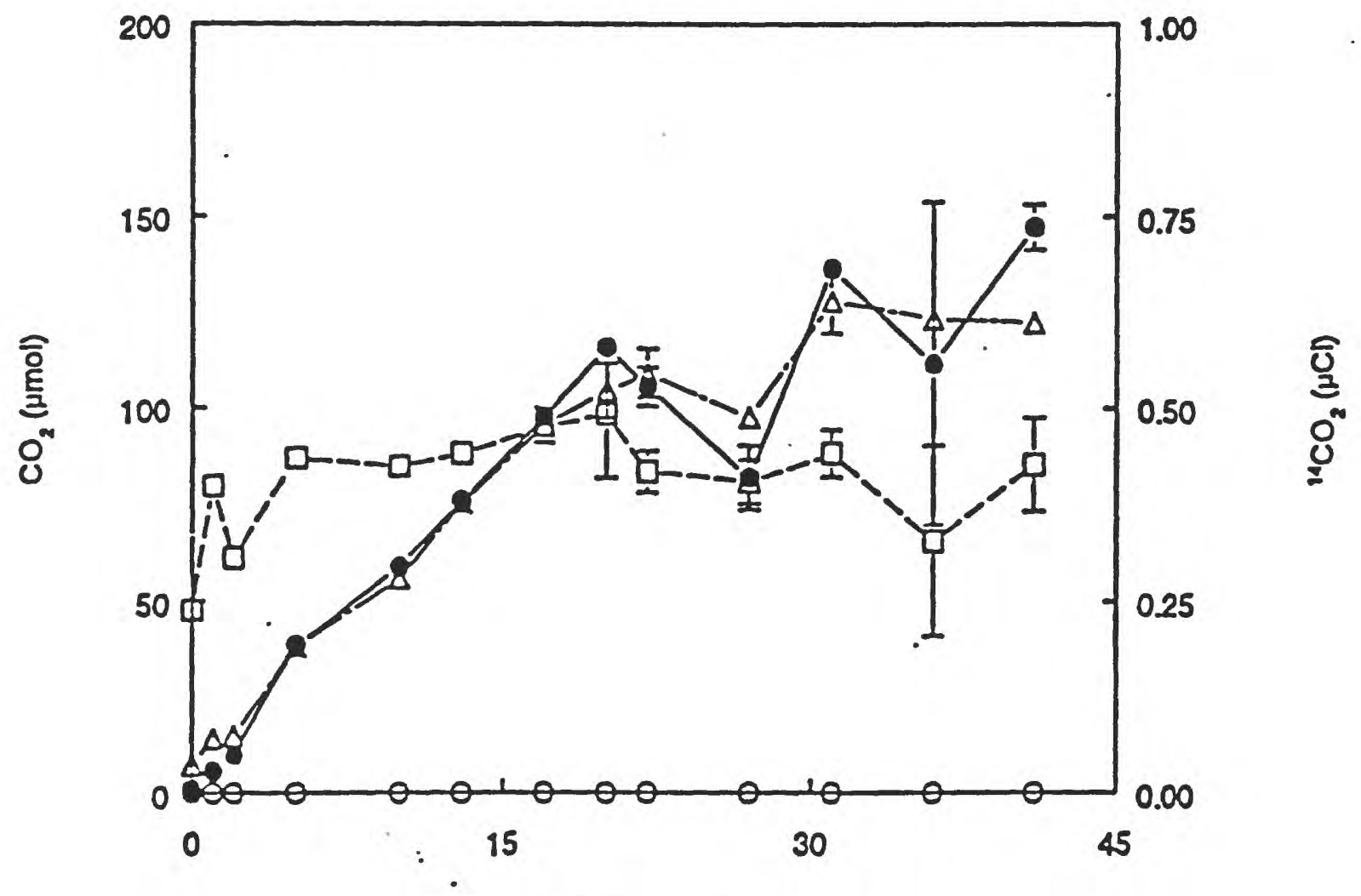

Time (days)

Figure 32. Forest soil from site 2, collected 7/79S. Slurried aerobically and anaerobically on 7/1 1/95. All received $0.91 \mu \mathrm{Ci}$ $(0.86 \mu M) 2.14 \mathrm{C}$-TFA Symbols: $\mathrm{CO}_{2}$ for $(\theta)$ anaerobic soil slurries $(\Delta)$ aerobic slurrier (D) autoclaved aerobic soil slurries (O) ${ }^{14} \mathrm{CH}_{4}$ and ${ }^{14} \mathrm{CO}_{2}$ for anzerobic slurries, which are representative resules for all conditions Symbols represent the mean of three individual slurries and bars indiease \pm 1 seandard deviation. 


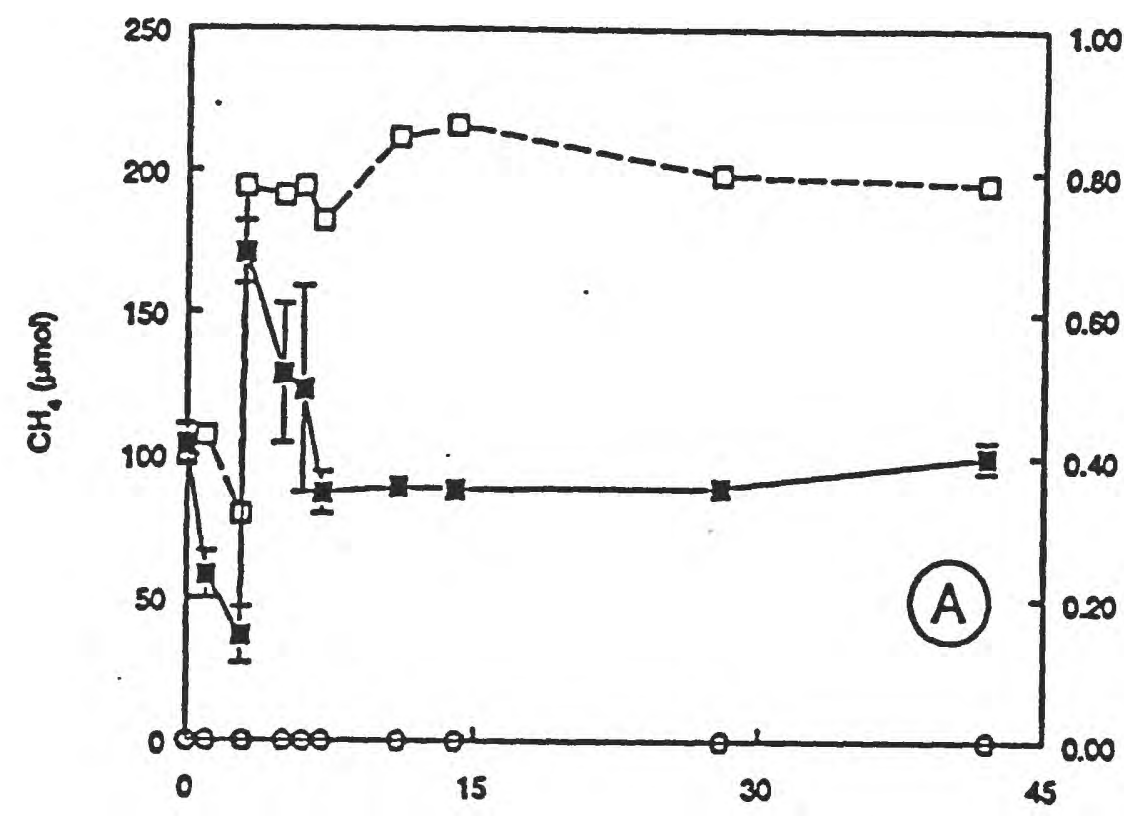

$\frac{\text { ఫ్ }}{\text { ఫ్ }}$

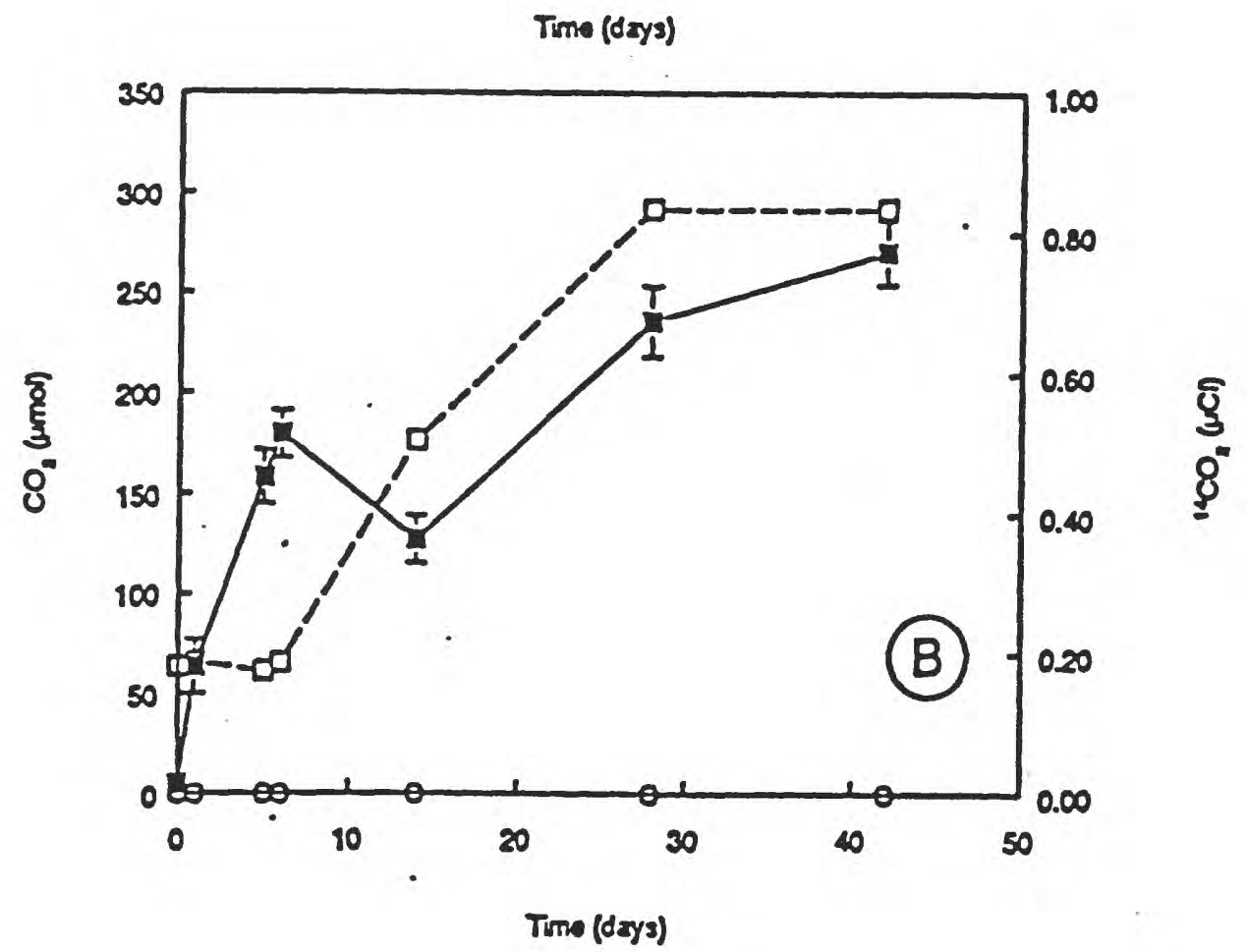

Figure 33. Forest soil collected $6 / 14 / 95$ and sluried aerobically on $6 / 30 / 95$ with $\mathrm{CH} 4$ and $\mathrm{O}_{2}$. All received $0.91 \mu \mathrm{Ci}(0.86 \mu \mathrm{M})$

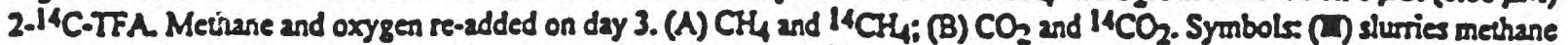
or oxygen; $(\square)$ autoclaved slurries with methane and oxygen; $(O)^{14} \mathrm{CH}_{4}$ and ${ }^{14} \mathrm{CO}_{2}$ for live sluries with methane and oxygem, which are representavive results for all conditions. Symbols represent the mean of three individual sluries and bars indicate \pm 1 standard deviacion, except for autoclaved slurries (D) where multiple samples were not done. 


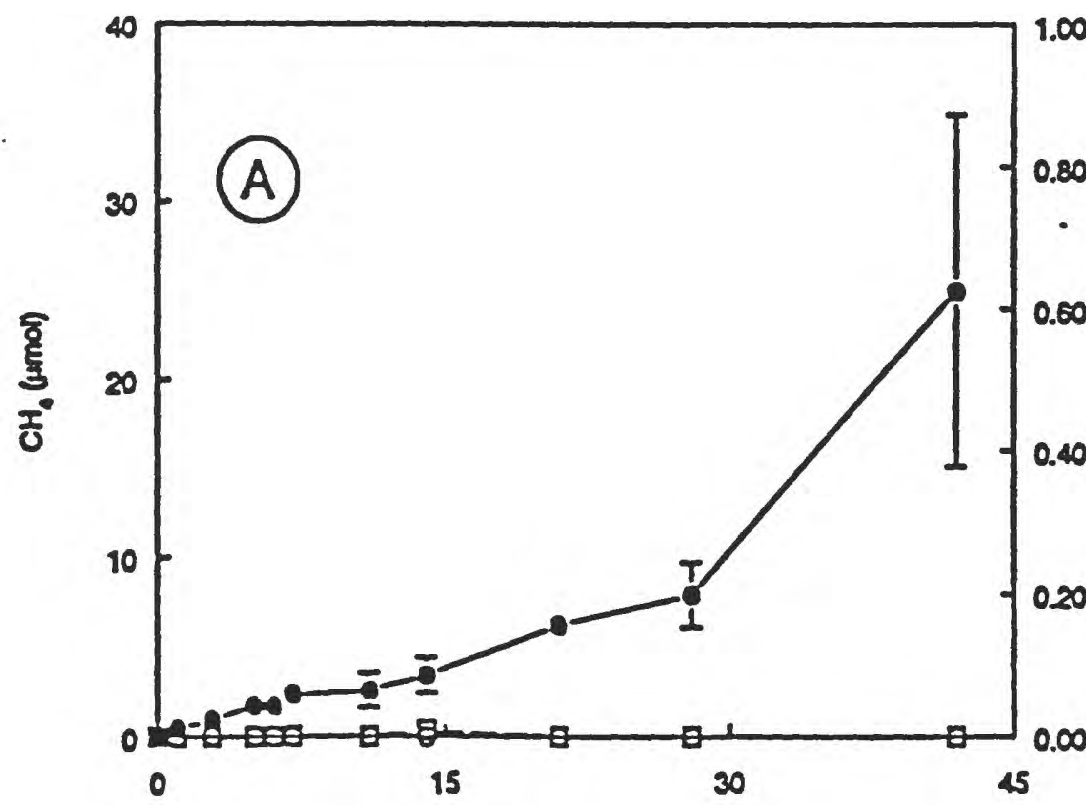

$\frac{\text { Qิ }}{9}$

Tomo (days)

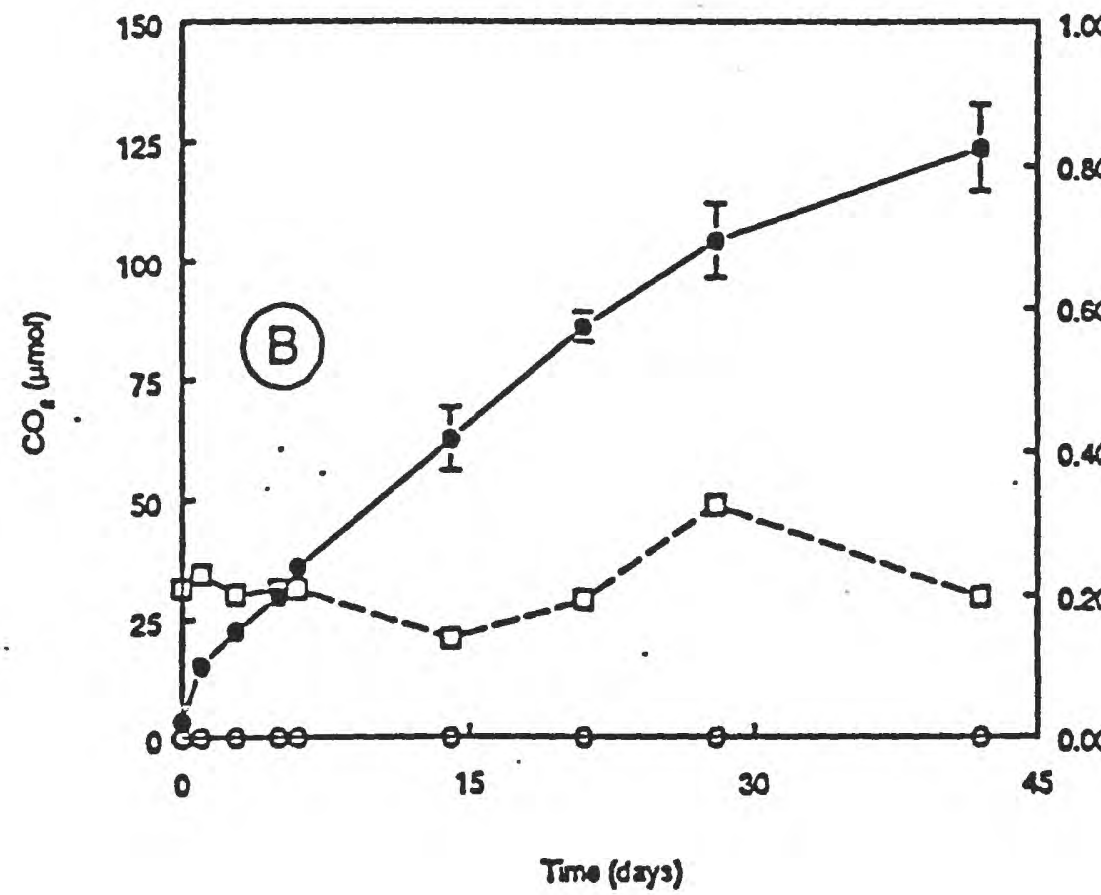

1.00

0.80

0.60

$\frac{8}{3}$

Figure 34. Forest soil collected 6/14/95 and slurried anaerobieally on 6/30/95 with $5 \mathrm{mM}$ sulfate. All received I $\mu \mathrm{Ci}(0.94 \mu \mathrm{M})$ 2.14C. TFA. (A) $\mathrm{CH}_{4}$ and ${ }^{14} \mathrm{CH}_{4} ;(B) \mathrm{CO}_{2}$ and ${ }^{14} \mathrm{CO}_{2}$. Symbols: (O) slurries with sulfate (D) autoclaved slurries with sulfate; (O) ${ }^{1+} \mathrm{CH}_{4}$ and $14 \mathrm{CO}_{2}$ for live slurries, which are representavive results for all conditions Symbols represent the mean of three individual slurries and bars indiease \pm 1 standard deviation, exeept for autoclaved slurries (D) where multiple samples were not done. 

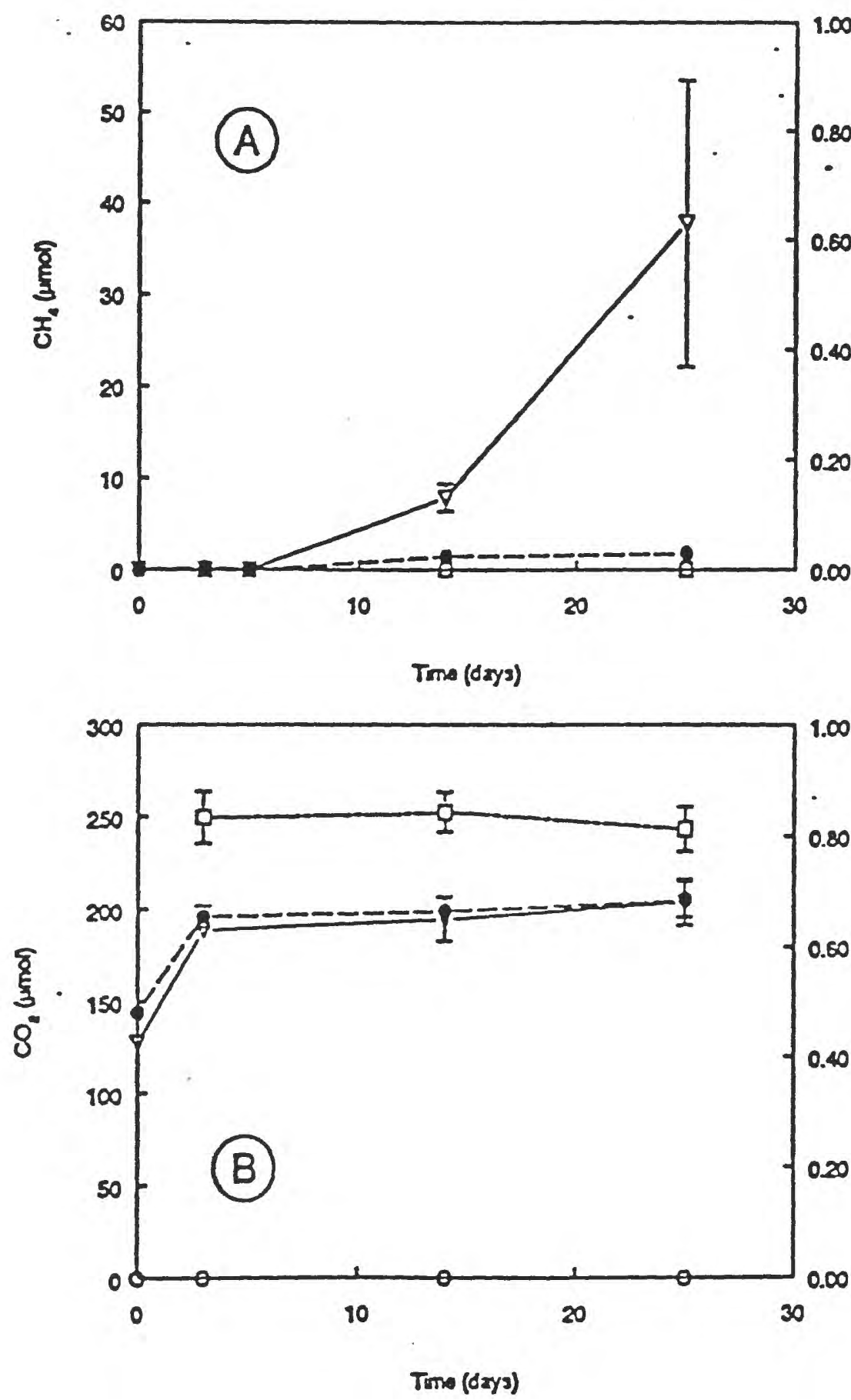

$\frac{\text { ఫิ }}{\text { ఫ్ }}$

ind (dxy)

Figure 35. Forest soil collected $77 / 95$ and sluried anaerobically on 825/95 with 5 mM sulfate in phosphate buffered medium, pH 6.8. All received $0.91 \mu \mathrm{Ci}(0.86 \mu \mathrm{M}) 2.14 \mathrm{C}$-TFA. (A) $\mathrm{CH}_{4}$ and ${ }^{14} \mathrm{CH}_{4}$ : $(\mathrm{B}) \mathrm{CO}_{2}$ and ${ }^{14} \mathrm{CO}_{2}$. Symbols (V) slurries without

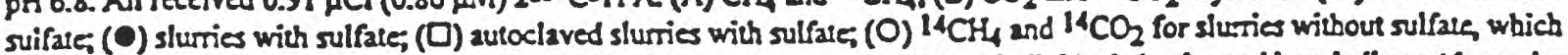
are representative results for all conditions. Symbols represens the mean of three individual slurries and bars indieate \pm 1 seandard deviation. 

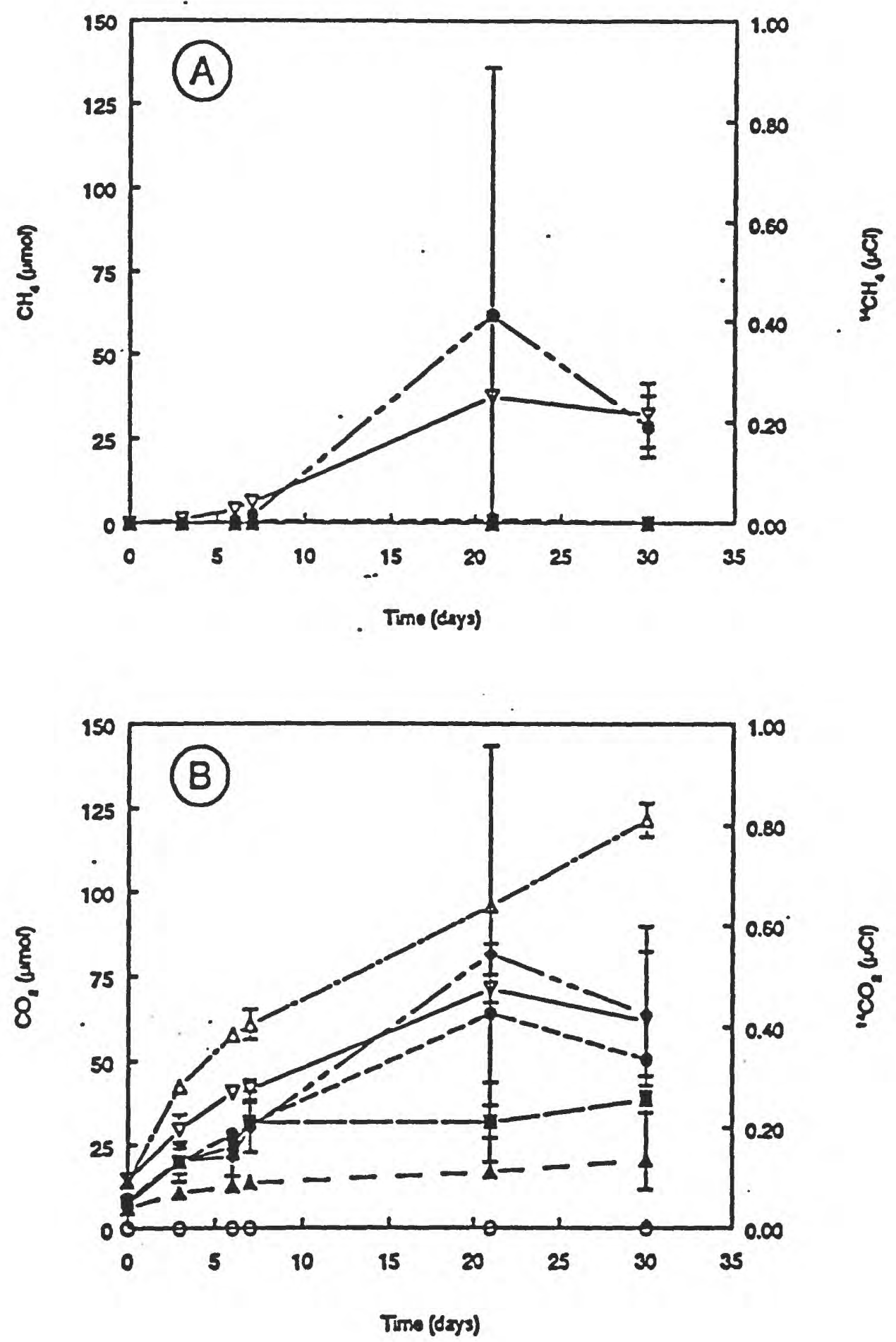

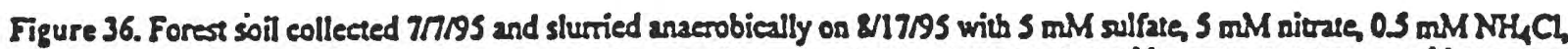
$5 \mathrm{mM}$ aceate, or $0.1 \mathrm{mmoll}$ FeOOH, where indieated. All received $0.91 \mu \mathrm{Ci}(0.86 \mu \mathrm{M}) 2.14 \mathrm{C}$-TFA. (A) CH4 and $14 \mathrm{CH}$; (B)

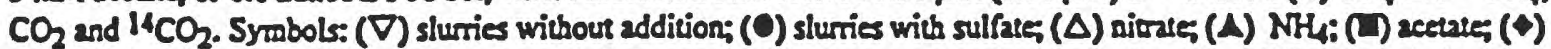
FeOOH; $(O)^{14} \mathrm{CH}_{4}$ and ${ }^{14} \mathrm{CO}_{2}$ for unamended slurries which are representative results for all conditions Symbols represent the mean of three individual slurries and bars indicate \pm 1 standard deviation. 

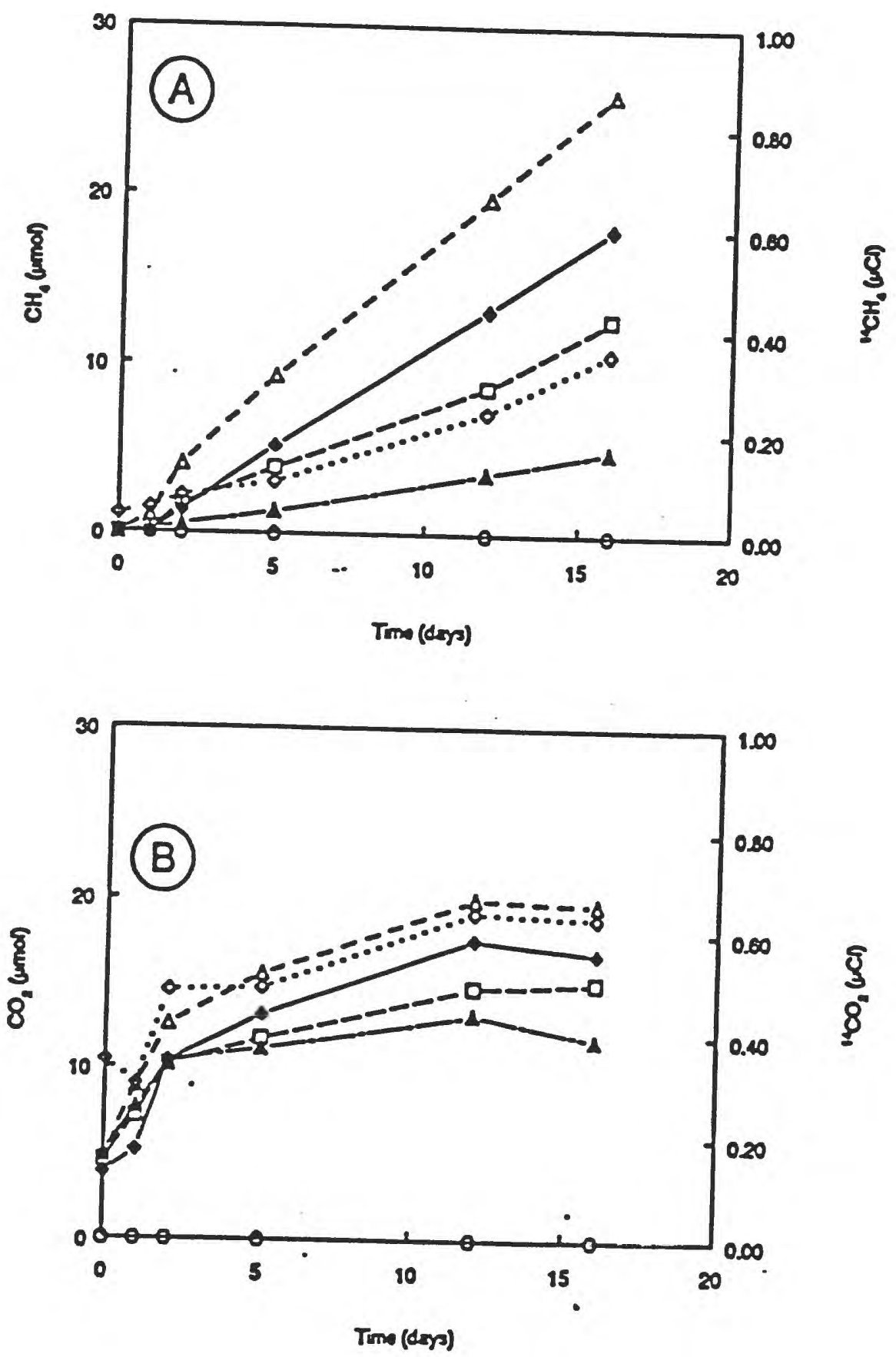

Figure 37. South San Francisco Bay saitransh small core experiment Core collected on 3/31/35, incubated on the bench in sunlight until it was subeored on 6/6/95. All received $0.2 \mu \mathrm{Ci}$ (12 amoVmL) 2.14 C.TFA. (A) CH4 and $14 \mathrm{CH}_{4}$ : (B) CO $\mathrm{CO}_{2}$ and

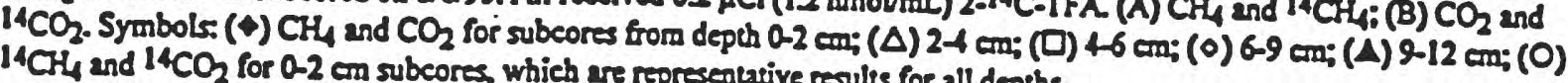



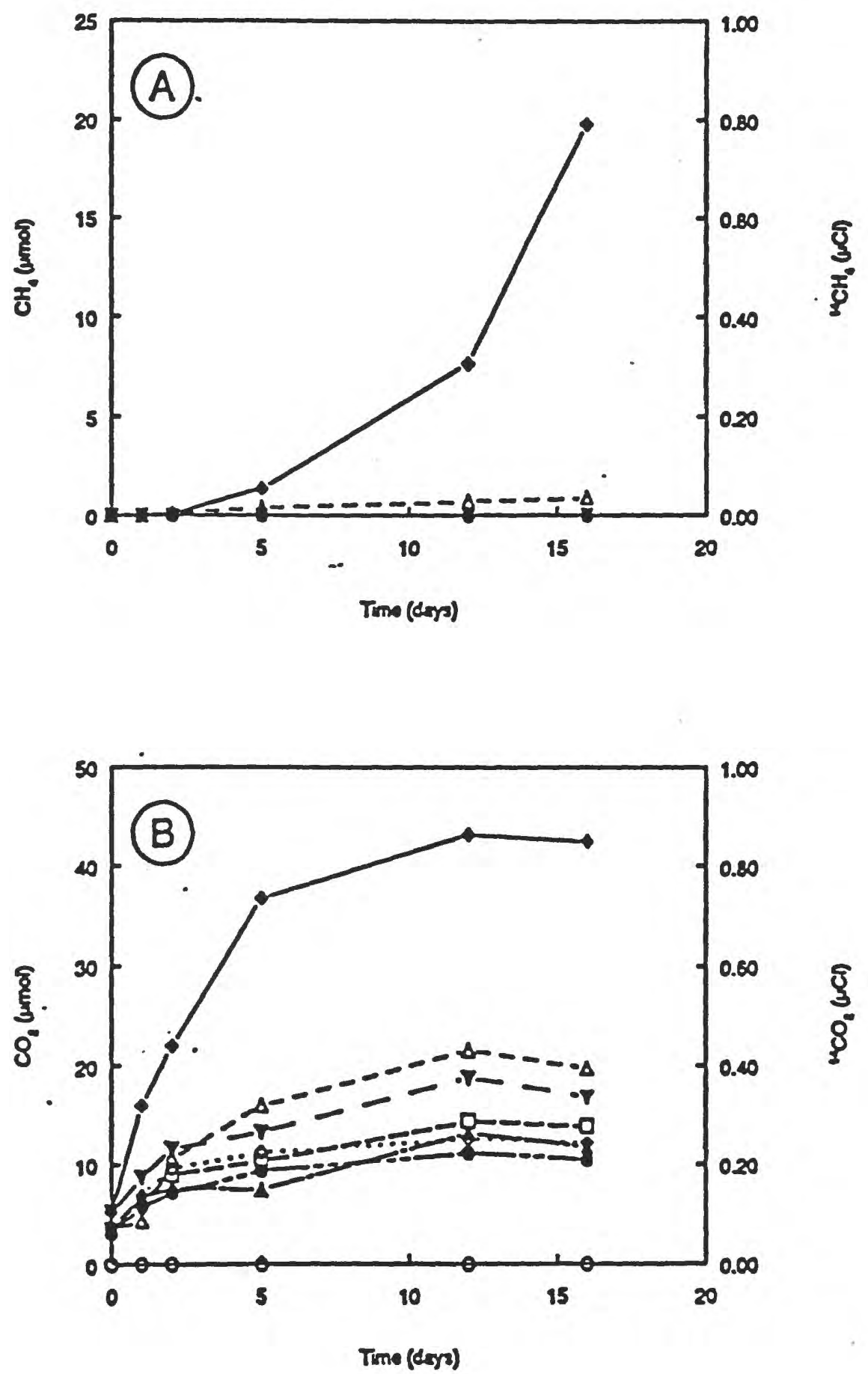

Figure 38. Sourh San Franeiseo Bay salomarsh small core experiment. Core collected on S/3/9S, iscubated oa the bench in sunlight uneil it was subcored on 6/6/95. All received $0.2 \mu \mathrm{Ci}(1.2 \mathrm{imolmL}) 2.14 \mathrm{C}$. IFA. (A) CH4 and 14 CH4, only depets 0.2 $\mathrm{cm}$ and $24 \mathrm{~cm}$ produced $\mathrm{CH}_{4} ;(B) \mathrm{CO}_{2}$ and $14 \mathrm{CO}_{2}$. Symbols $(\bullet) \mathrm{CH}_{4}$ and $\mathrm{CO}_{2}$ for subeores from depth $\mathrm{O}_{2} \mathrm{~cm}$ ( $\triangle(\Delta) 24 \mathrm{~cm} ;($

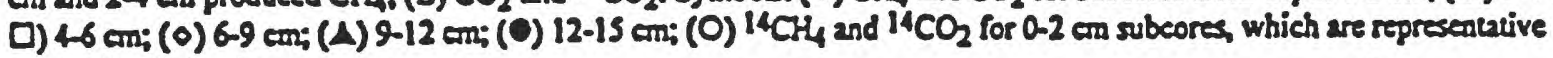
results for all depths. 

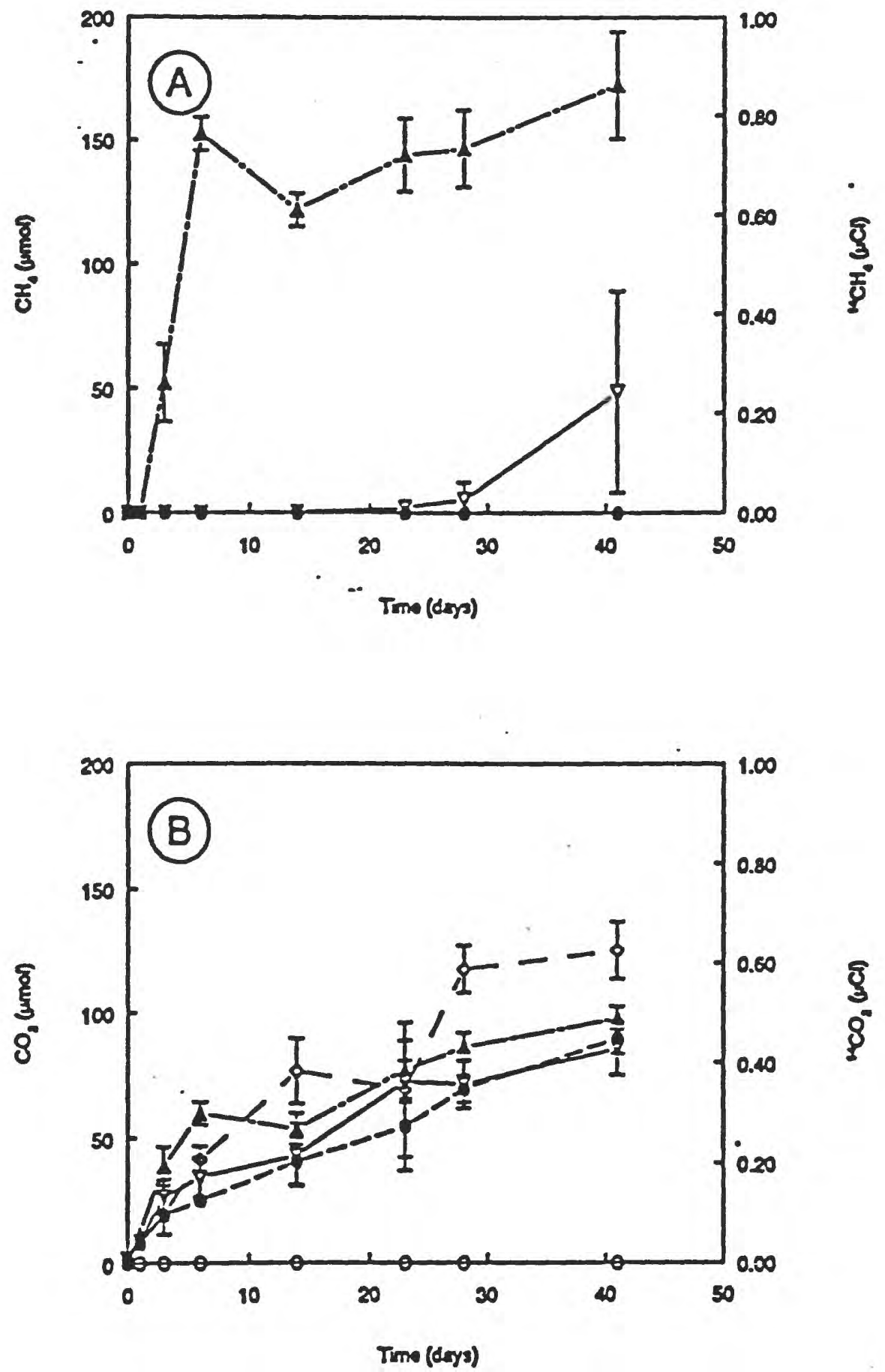

Figure 39. San Franeiseo Marina small core experinent. Core collected on 5/12/95, stored a $4^{\circ} \mathrm{C}$, and subcored serobically and anaerobically on $5 / 16993$. Where indicated $20 \mathrm{mM}$ sulfare, or $10 \mathrm{mM}$ TFA were added 10 anaerobic cores All received

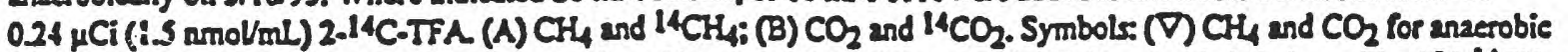
subcores without sulfase or TMA; $(\theta)$ anaerobic, sulfate-amended; $(A)$ anserobic, TMA-amended; $(0)$ aerobie, $(O){ }^{14} \mathrm{CH}_{4}$ and $14 \mathrm{CO}$ for unameaded anaerobic subcores, which are representative results for all depths Symbols represent the mean of three individual slurries and bars indicale $\pm l$ standard deviation. 

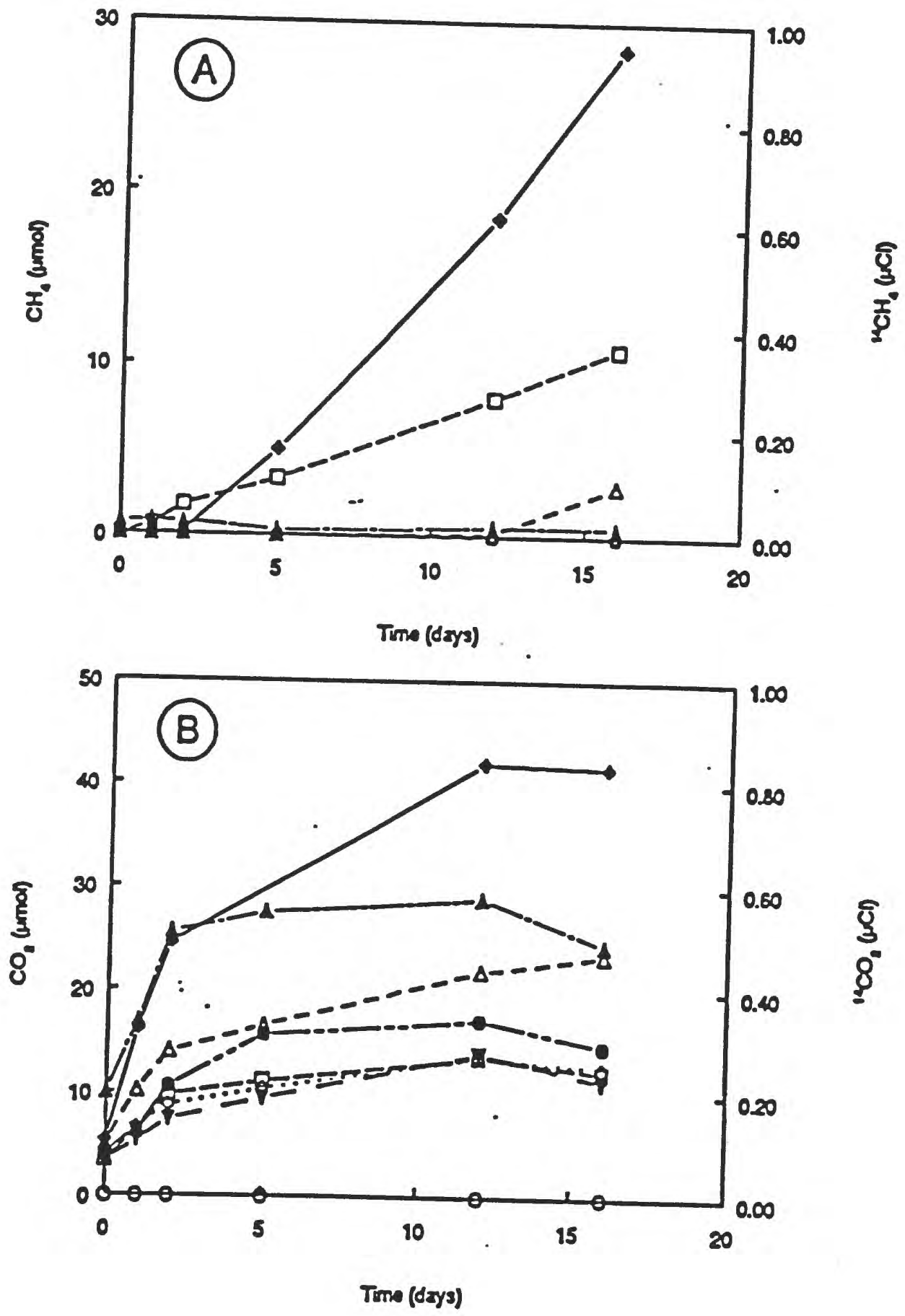

Figure 40. Bolinas Bay smaii core experiment. Cores collected on 5/23/95 and subcored anaerobically on 67/95. All received $0.2 \mu \mathrm{Ci}\left(1.2 \mathrm{amol} / \mathrm{mL}\right.$ ) $2.14 \mathrm{C}$. TFA (A) CH4 and ${ }^{14} \mathrm{CH}_{4}$; (B) $\mathrm{CO}_{2}$ and ${ }^{14} \mathrm{CO}_{2}$. Symbols ( $\bullet$ ) $\mathrm{CH}_{4}$ and $\mathrm{CO}_{2}$ for subeores from

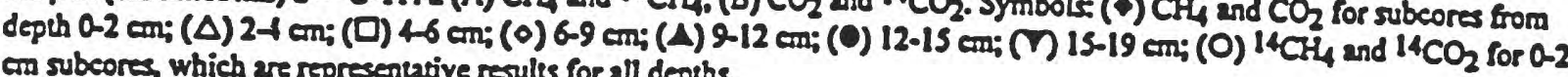
con subcores, which are representative results for all depths. 

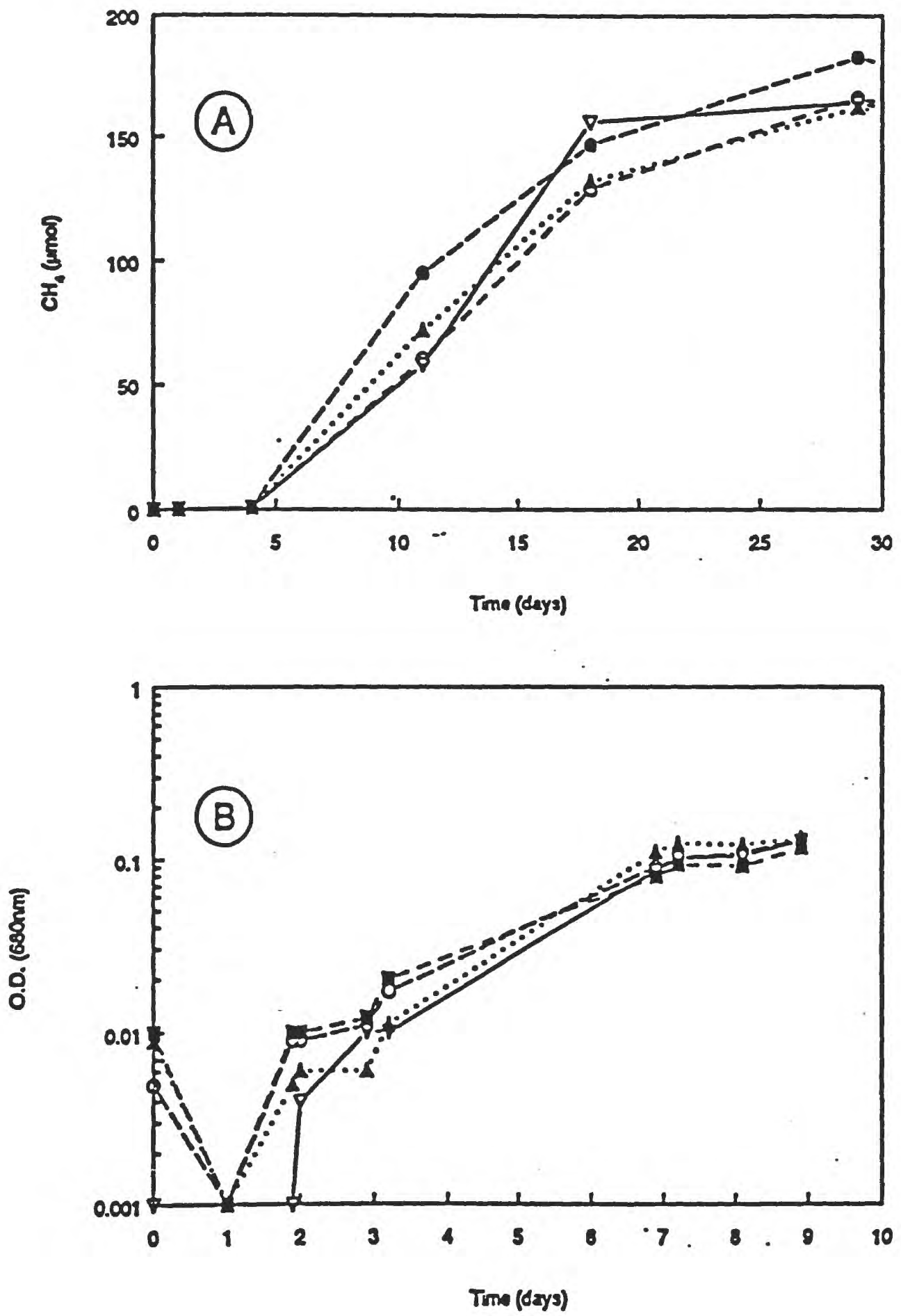

Figure 4l. Effects of $O$ wo I mM TFA concentrations on $(A)$ methanogenesis of Methanasareina mesel S-6 growing on $20 \mathrm{mM}$ acetate, and (B) optical density of Desulfobceter curvatus growing on $20 \mathrm{mM}$ acetate. Both incubated statically at $28^{\circ} \mathrm{C}$ Symbols: (V) CH4 for cultures without TFA addition; (D) $0.1 \mu \mathrm{M}$ TFA; (O) $10 \mu \mathrm{M}$ TFA; (O) $100 \mu \mathrm{M}$ TFA; (A) I mM TFA. 


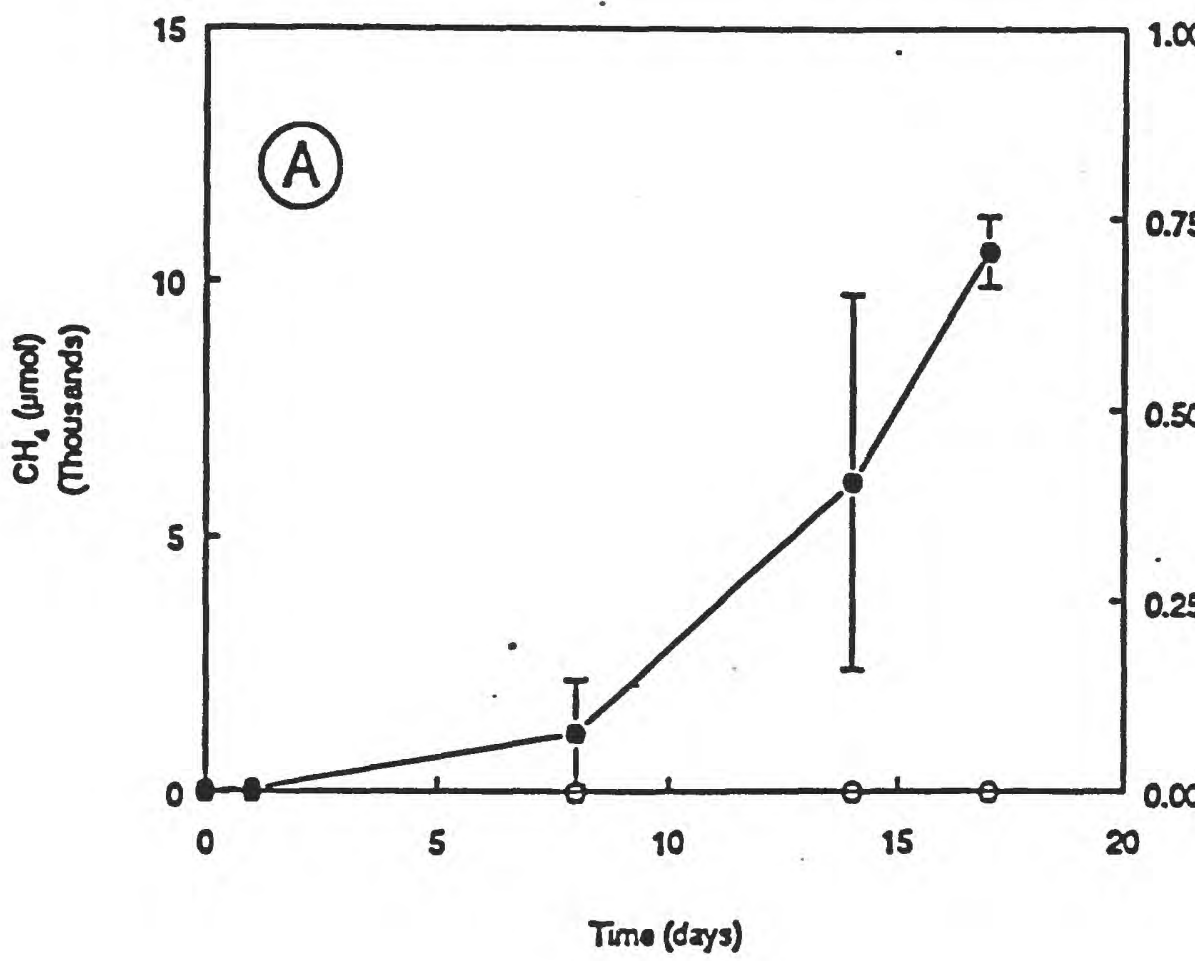

3
3
3

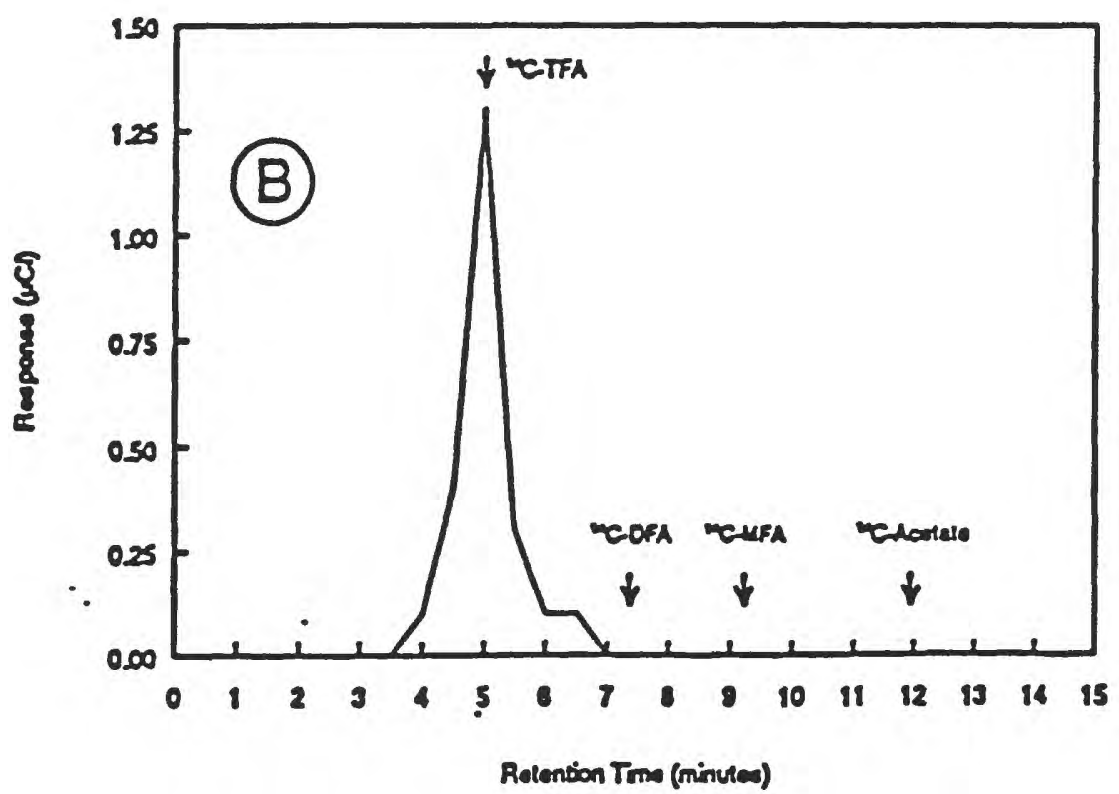

Figure 12. Methenosareine meel S-6 growing on $20 \mathrm{mM}$ acetate in the presence of $0.4 \mu \mathrm{Ci}(0.75 \mu \mathrm{M}) 2.14 \mathrm{C}$-TFA. (A) CH4 and 14CH4: (B) HPLC aralysis of a liquid-phase sample taken at end of experiment showing presence of ItC.TFA and absence of ${ }^{14} C$-DFA, ${ }^{14} C$-MFA, and $14 C$-aceeate. Symbols in $(A)$ represent the mean of three individual cultures and bars indieare \pm 1 standard deviation. Duplicate analyses not shown in (B). 